Florida International University FIU Digital Commons

$11-13-1998$

\title{
Content-Area teachers' perceptions of the effect of the meta training on their instructional practices
}

Sylvia R. Crespo

Florida International University

DOI: $10.25148 /$ etd.FI14061542

Follow this and additional works at: https://digitalcommons.fiu.edu/etd

Part of the Curriculum and Instruction Commons

\section{Recommended Citation}

Crespo, Sylvia R., "Content-Area teachers' perceptions of the effect of the meta training on their instructional practices" (1998). FIU Electronic Theses and Dissertations. 2667.

https://digitalcommons.fiu.edu/etd/2667 
FLORIDA INTERNATIONAL UNIVERSITY

Miami, Florida

CONTENT-AREA TEACHERS' PERCEPTIONS

OF THE

EFFECT OF THE META TRAINING

ON THEIR

INSTRUCTIONAL PRACTICES

A dissertation submitted in partial fulfillment of the

requirements for the degree of

DOCTOR OF EDUCATION

in

CURRICULUM AND INSTRUCTION

by

Sylvia R. Crespo

1998 
To: Dean Robert Vos

College of Education

This dissertation, written by Sylvia R. Crespo, and entitled Content-area Teachers' Perceptions of the Effect of the META Training on Their Instructional Practices, having been approved in respect to style and intellectual content, is referred to you for your judgment.

We have read this dissertation and recommend that it be approved.

Patricia A. Killian

Paul A. Rendulic

Judith J. Slater

Stephen M. Fain, Major Professor

Date of Defense: November 13, 1998

The dissertation of Sylvia R. Crespo is approved.

Dean Robert Vos

College of Education

Dean Richard L. Campbell

Division of Graduate Studies

Florida International University, 1998 
(C) Copyright 1998 by Sylvia R. Crespo

All rights reserved. 


\title{
DEDICATION
}

\author{
It is with both \\ joy - that the journey she inspired has come to an end \\ and \\ Sorrow - that she is not there to see its culmination \\ that I dedicate this dissertation to my former professor and mentor: \\ Dr. Lorraine R. Gay
}




\section{ACKNOWLEDGMENTS}

The road to my doctoral degree has been a long one and as I approach its end I look back and see all those who have helped me on my way. To the peers in my graduate studies with whom I shared insights and discussions, I thank you. To all of my professors in my doctoral studies who provided a gateway to knowledge, I thank you. I especially want to give thanks to the members of my committee who have so willingly provided their time, encouragement, expertise, critical analysis, and invaluable help: Dr. Stephen M. Fain, Dr. Patricia A. Killian, Dr. Paul A. Rendulic, and Dr. Judith J. Slater.

This journey would not have been completed without the support of my professional colleagues and friends. To all of my professional colleagues who provided their support, assistance, encouragement, and expertise, I thank you. I would like to thank both my former principal, Dr. Lynda P. Carroll, and my present supervisor, Mrs. Rosalia Gallo, who encouraged me to proceed. To Dr. Joseph J. Gomez, Dr. Daniel Tosado, Mr. Russell Feldman, Mr. Jim O’Donnel, Ms. Twila Grandchap, Ms. Kirsty Bray, Ms. Mercedes Toural, Ms. Lourdes Rovira, Ms. Betty Pereira, Ms. Silvia Diaz, Mr. Oscar Fragas, and Ms. Esther Sobrino, I offer my thanks for their help. I give a special thanks to all of my dear beloved friends who have listened so patiently, shared their ideas, rearranged outings, and most of all were there for me when I needed their support.

It is time to acknowledge those without whose undying love, unlimited patience, and total support this journey would have been impossible -my family. To my brother, sister-in-law, nephews, niece, and cousins who always wanted to know how it was going, I thank you. I give thanks to my mother-in-law for the 
loving thoughts and long distance encouragement. I give my love and thanks to my parents whose belief in me and pride in my accomplishments has inspired me to continue to strive towards new goals. I now need to give thanks to those who have traveled every inch of this road with me, who have endured my moods, my stress, my lack of time and done so with so much love. To my son, Hector, I thank you for your witty comments which helped to alleviate my stress. You have grown into a handsome, caring young man that your father and I love and are proud of. To my daughter, Seisha, who so lovingly and patiently waited for me to have some time for her and who worried when I was stressed, I thank you. You have grown into a lovely, thoughtful young lady who fills your parents' hearts with love and pride. Finally, to my husband and other half, Hector Ivan, whose love, nurturing, and respect have given me the freedom to grow as an individual and yet maintain that bonding of the spirits which makes us one, I love you and thank you. In closing, I want each and everyone of you to know that I could not have done it without you. Thank you all from the bottom of my heart. 


\author{
ABSTRACT OF THE DISSERTATION \\ CONTENT-AREA TEACHERS' PERCEPTIONS OF THE \\ EFFECT OF THE META TRAINING ON THEIR \\ INSTRUCTIONAL PRACTICES \\ by \\ Sylvia R. Crespo \\ Florida International University, 1998 \\ Miami, Florida \\ Professor Stephen M. Fain, Major Professor
}

The purpose of this study was to explore the content-area teachers' perceptions of the effect that compliance with the teacher training for content-area teachers of Limited English Proficient (LEP) students mandated by the Consent Decree had on their instructional practices within the content-area classroom. In order to provide an overview of the factors which had an effect on the content-area teachers' mandated training, various areas were reviewed: history of legislative actions that led up to the Consent Decree; stipulations set forth in the Consent Decree; Miami-Dade County Public Schools District LEP Plan including stipulations for teacher training; research on teacher training for teachers of language minority students; and the process of change. This descriptive study specifically addresses teachers' perceptions of the effectiveness of the mandated teacher training as it relates to language minority students. 
Content-area teachers who had completed the mandated teacher training were surveyed using self-administered anonymous questionnaires mailed to their school sites. Questions focused on the teachers' perceptions of: students' need of second language instructional strategies within the content-area classroom; teacher training requirements mandated by the Consent Decree; and changes in their instructional practices as a result of the training.

Based on the responses of the subjects, the results of this study indicate the overall success of the training implemented to comply with the stipulations set forth in the Consent Decree. In general, the results indicate that the teachers perceive that they are ultimately in agreement with the mandated training. The results also indicate that the teachers perceive a need for second language strategies when working with language minority students. These results can serve as starting point for further research not only into teachers' perceptions of the effectiveness of training for teachers of language minority students but also into the outcomes of this teacher training as it is reflected within the classroom. 


\section{TABLE OF CONTENTS}

CHAPTER

Page

I. INTRODUCTION

1

The Research Question 6

Subsidiary Questions $\quad 7$

Limitations $\quad 8$

Assumptions $\quad 8$

Definition of Terms 9

II. LITERATURE REVIEW 11

Introduction 11

History of Legislative Action $\quad 11$

Miami-Dade County District LEP Plan 25

Teacher Training $\quad 27$

Summary 41

III. METHODOLOGY AND PROCEDURES 42

Conceptualization $\quad 42$

Research Rationale $\quad 42$

Definition of the Population 44

Definition of the Sample 44

Quantitative Descriptive Design $\quad 45$

Procedures $\quad 50$

Statistical Analysis $\quad 51$

Summary $\quad 55$

IV. RESULTS

Data Analysis $\quad 56$

Subsidiary Question One $\quad 58$

Subsidiary Question Two 74

Subsidiary Question Three $\quad 92$

Subsidiary Question Four $\quad 110$

Subsidiary Question Five $\quad 115$

Subsidiary Question Six 116

Subsidiary Question Seven $\quad 117$

Subsidiary Question Eight 118

$\begin{array}{ll}\text { Subsidiary Question Nine } & 119\end{array}$

$\begin{array}{ll}\text { Summary } & 120\end{array}$ 
$\begin{array}{ll}\text { V. DISCUSSION } & 125\end{array}$

Summary of the Study $\quad 125$

Findings 125

Subsidiary Question One $\quad 125$

Subsidiary Question Two 128

Subsidiary Question Three 130

Subsidiary Question Four $\quad 135$

Subsidiary Question Five $\quad 137$

Subsidiary Question Six $\quad 137$

Subsidiary Question Seven $\quad 138$

Subsidiary Question Eight 138

Subsidiary Question Nine $\quad 138$

Summary of the Findings $\quad 139$

Conclusion 145

Recommendations for Future Research 146

$\begin{array}{ll}\text { Summary } & 148\end{array}$

LIST OF REFERENCES 149

$\begin{array}{lr}\text { APPENDICES } & 159\end{array}$

$\begin{array}{ll}\text { VITA } & 177\end{array}$ 


\section{LIST OF TABLES}

Table

Table 1

Distribution of Questionnaires Sent and Returned

Table 2

Means and Standard Deviations of Questionnaire

Items 12 through 21 by Content-area

Table 3

Teachers' Perceptions of Item 12 by Content-area

Table 4

Teachers' Perceptions of Item 13 by Content-area

Table 5

Teachers' Perceptions of Item 14 by Content-area

Table 6

Teachers' Perceptions of Item 15 by Content-area

Table 7

Teachers' Perceptions of Item 16 by Content-area

Table 8

Teachers' Perceptions of Item 17 by Content-area

Table 9

Teachers' Perceptions of Item 18 by Content-area

Table 10

Teachers' Perceptions of Item 19 by Content-area

Table 11

Teachers' Perceptions of Item 20 by Content-area

Table 12

Teachers' Perceptions of Item 21 by Content-area 
Table 13

Means and Standard Deviations of Questionnaire Items 22 through 32 by Content-area

Table 14

Teachers' Perceptions of Item 22 by Content-area

Table 15

Teachers' Perceptions of Item 23 by Content-area

Table 16

Teachers' Perceptions of Item 24 by Content-area

Table 17

Teachers' Perceptions of Item 25 by Content-area

Table 18

Teachers' Perceptions of Item 26 by Content-area

Table 19

Teachers' Perceptions of Item 27 by Content-area

Table 20

Teachers' Perceptions of Item 28 by Content-area

Table 21

Teachers' Perceptions of Item 29 by Content-area

Table 22

Teachers' Perceptions of Item 30 by Content-area

Table 23

Teachers' Perceptions of Item 31 by Content-area

Table 24

Teachers' Perceptions of Item 32 by Content-area

Table 25

Means and Standard Deviations of Questionnaire 
Table 26

Teachers' Perceptions of Item 33 by Content-area

Table 27

Teachers' Perceptions of Item 34 by Content-area

Table 28

Teachers' Perceptions of Item 35 by Content-area

Table 29

Teachers' Perceptions of Item 36 by Content-area

Table 30

Teachers' Perceptions of Item 37 by Content-area

Table 31

Teachers' Perceptions of Item 38 by Content-area

Table 32

Teachers ${ }^{9}$ Perceptions of Item 39 by Content-area

Table 33

Teachers' Perceptions of Item 40 by Content-area

Table 34

Teachers' Perceptions of Item 41 by Content-area

Table 35

Teachers' Perceptions of Item 42 by Content-area

Table 36

Teachers' Perceptions of Item 43 by Content-area

Table 37

Multivariate Factorial Analysis of Variance for

Content-area Teachers' Perceptions of the

Mandated Teacher Training by Gender, Age,

Race, and Bilingualism 
Table 38

Post Hoc Analysis

Table 39

Multivariate Factorial Analysis of Variance for Content-area Teachers' Perceptions of the

Need for Second Language Instructional Strategies

by Years of Teaching, Teaching Assignment, and

Content-area

Table 40

Multivariate Factorial Analysis of Variance for

Content-area Teachers' Perceptions Concerning the

Application of Second Language Instructional Strategies

by Years of Teaching, Teaching Assignment, and

Content-area

Table 41

Multivariate Factorial Analysis of Variance for

Content-area Teachers' Perceptions of the

Mandated Teacher Training by How They Were Trained

(Complian) and When They Were Trained (YrTrain)

Table 42

Multivariate Factorial Analysis of Variance for

Content-area Teachers' Perceptions of the

Need for Second Language Instructional Strategies

by How They Were Trained (Complian) and

When They Were Trained (YrTrain)

Table 43

Multivariate Factorial Analysis of Variance for

Content-area Teachers' Perceptions of the

Need for Second Language Instructional Strategies

by How They Were Trained (Complian) and

When They Were Trained (YrTrain)

Table 44

Distribution of the Racial/Ethnic Background of

Respondents to the Questionnaire 


\section{CHAPTER ONE \\ INTRODUCTION}

Students in ever-increasing numbers are entering the public educational system with a limited knowledge of English. Since English is the language of the schools and of society, the lack of English skills can curtail these students' opportunities for an education equal to that of native English-speaking children and contribute to their marginalization (Ambert \& Melendez, 1985; Brown, 1992; Grundy, 1992; McKay \& Weinstein-Shr, 1993). In other words, the students' lack of proficiency in English can lead to a lack of academic achievement and form a barrier to accessing educational opportunities within the system. Consequently, many of the parents of these language minority students are "concerned with the quality of education which their children receive and are aggrieved by the failure of the school district to provide their children with adequate educational programs" (Valle, Franco, \& Rodriguez-Garcia, 1979, pp. 58-59). These parents feel that their children's educational needs are not being served by the educational system.

This parental concern led to the use of the political process and the courts as a means by which their community hoped to bring about a change in the educational system and thus achieve equality of educational opportunity for their children (Applewhite, 1979; Martinez, 1979; Matute-Bianchi, 1979). These parents' pursuit of change in the educational system to achieve equality of educational opportunity for their children has been and continues to be a struggle as many educators remain unaware of students' multilingual and multicultural 
backgrounds and how these backgrounds can affect these students' participation in the educational system (Brisk, 1982; Dalton \& Moir, 1991; Hamayan, 1990).

There are those who feel that making the educational system more responsive to the needs of language minority students is difficult since schools are structured to maintain the status-quo. As explained by Bennet and LeCompte (1990):

Functionalism has been the prevailing theoretical framework in the social sciences throughout the twentieth century. . . Functionalists view educational systems as one of the structures which carry out the function of transmission of attitudes, values, skills and norms from one generation to another. ... According to functionalists, educational systems perpetuate the "accepted", or dominant culture. The concept of "accepted culture" implies the existence of consensus on the values, attitudes, and behaviors that should be transmitted by the schools to children. When conflict over values does occur, adjustments and adaptations are made to regain a state of consensus and to keep the entire system balanced (pp. $5-6)$.

In other words, schools serve as a socializing agent. "The educational system prepares students to be able to perform tasks and occupy the social roles necessary to the social, political, and economic functioning of society" (Spener 1988, p. 133). As stated previously, language minority students' lack of proficiency in English can form a barrier to accessing educational opportunities within the system and ultimately affect their ability to function optimally within the social system. According to Weismantel and Fradd (1989), "meeting the 
educational needs of these students becomes imperative if these students are to become productive members of society. Educational success for these students is a goal relevant to the maintenance of a democratic society" (p. 6). The battle for equality of educational opportunity continues to be waged today as lawsuits have been filed on behalf of language minority students in a continuing effort to have school systems comply with prior legislative actions (Brisk, 1982; Florida Department of Education, 1995). According to Valle et al. (1979), "lawsuits can be a tool for ... communities to organize against school officials. ... They may also provide the stimulus for the passage of state legislation." (p. 77). In Osceola County, Florida, a major lawsuit was filed on behalf of language minority students and its resolution had major effects on all districts throughout the state. Out-of-court negotiations led to an agreement between the plaintiffs and the defendants in League of Latin-American Citizens (LULAC) et al. v. State Board of Education of Florida (1990). This agreement became part of a consent decree signed on August 14, 1990 in the United States District Court for the Southern District of Florida. The Consent Decree provided a structure to enable the Florida school districts to comply with federal laws concerning the rights of language minority students through the use of Limited English Proficient (LEP) Plans regarding the identification and provision of services to these students (Florida Department of Education, 1995). The Consent Decree does not specify particular instructional methodology, leaving this to the school districts who might provide services through various instructional delivery methods. The only stipulation is that equal access to program subject matter, content, benefits, and comprehensible instruction by appropriately certified personnel must be 
guaranteed to all LEP students, including exceptional students (Florida Department of Education, 1995). The Consent Decree focuses on the rights of the LEP students to be provided with academic instruction in English that is understandable to them. This stipulation requires that all educators who come into contact with LEP students be trained in the use of techniques, methods, and strategies to be utilized when instructing students who lack proficiency in English in order to provide these students with academic instruction that they can understand.

The focus of this study is to explore the teachers' perceptions regarding the effect the training for content-area teachers of LEP students, as mandated by the Consent Decree, has had on their instructional practices within the content-area classroom. This focus is important because "court intervention in educational matters may serve to alienate many teachers $\ldots$ to the extent that the merit of court-ordered programs becomes muddled" (Valle et al., 1979, p. 76). Although the Consent Decree was but one of a long list of legislative actions taken on behalf of language minority students, it appears some educators acted as if this type of legislation and subsequent training was a new right being granted to these students. This assertion is substantiated by the following clarification statement found in a memorandum titled Some Issues Regarding the Education of Language Enriched Pupils (LEP) in the state of Florida: A Restatement from the Florida Department of Education, "The Consent Decree has not created new rights for LEP students. The LEP plans that the Consent Decree mandates at the county level merely ensure the respect for and the protection of the long-established constitutional rights of LEP students" (B. A. Garcia, personal 
communication, June 27, 1995). From this memorandum it can be seen that the State felt obligated to clarify that the Consent Decree was not providing any new rights to LEP students; what it was ensuring was awareness of prior established rights. The question arises as to what are the content-area teachers' perceptions regarding the teacher-training mandated by the Consent Decree and if these perceptions affect the actual implementation of the methods and strategies shown effective with the LEP student. Grant (1991) stated that, "it is important that research go beyond concepts of changing teacher beliefs and behaviors about working with diverse students. It is also important to understand how these teachers' beliefs and behaviors impact on classroom management and instructional preparation" (p. 450). According to Dalton and Moir (1991), Grant (1991), and Mercado and Sapiens (1992), there is little evidence that practice is changing to reflect training in strategies which facilitate the LEP students' comprehension of the content in the basic subject areas.

The purpose of this study is to explore the content-area teachers' perceptions of the effect that compliance with the mandated training for content-area teachers of LEP students has had on their instructional practices within the content-area classroom. This study can be considered a case study of the staff development project which was implemented in order to comply with the stipulations for teacher training set forth in the Consent Decree.

As a result of the Decree, all school personnel working with LEPs are required to have specific credentials. In 1990, because of the scarcity of personnel preparation programs for ESOL statewide, districts were given five years to develop the cadre of personnel needed to meet state 
requirements. As a consequence, districts have had to offer massive in-service programs. ... In-service credentialing requirements range from 18 in-service hours for school administrators, school psychologists, speech pathologists, and social workers, [to 60 hours for content-area teachers providing English, Mathematics, Science, Social Studies, and Computer Literacy instruction for LEPs], to 300 hours for classroom teachers providing language arts instruction for LEPs. The purpose of the ESOL endorsement is to enable educators to recognize the specific instructional needs of LEPs and to promote effective assessment and instructional practices (Fradd, Wilen, \& Fardig, 1998, pp. II-6-II-7).

In other words, the intent of the staff development project was to change the content-area teachers' behaviors with regard to increasing the effectiveness of the academic instruction provided to LEP students.

The review of literature provides an overview of the history of legislative actions that led to the Consent Decree, an overview of the stipulations set forth in the Consent Decree, and an overview of Miami-Dade County Public Schools District LEP plan for compliance with the agreement, especially as it affects teacher-training, including an overview of research on teacher-training for teachers of language minority students.

\section{THE RESEARCH QUESTION}

What perceived effect has the mandated teacher-training for content-area teachers of LEP students stipulated in the LULAC et al. v. State Board of Education of Florida (1990) Consent Decree had on these content-area teachers' instructional practices? 


\section{SUBSIDIARY QUESTIONS}

1. What are content-area teachers' perceptions concerning the LEP students' need of second language instructional strategies within the content-area classroom?

2. What are the content-area teachers' perceptions concerning the teacher-training requirement mandated in the Consent Decree?

3. What changes are perceived to have occurred in the content-area teachers' instructional practices as a result of the training?

4. Is there a significant difference in the content-area teachers' perceptions of the mandated teacher-training depending on their gender, race/ethnicity, age, and bilingualism?

5. Is there a significant difference in the content-area teachers' perceptions of the need for second language instructional strategies within the content-area classroom depending on their years of teaching, teaching assignment and content-area?

6. Is there a significant difference in the content-area teachers' perceptions concerning the implementation of second language instructional strategies within the content-area classroom depending on their years of teaching, teaching assignment and content-area?

7. Is there a significant difference in the content-area teachers' perceptions of the mandated teacher training depending on how they were trained and when they were trained? 
8. Is there a significant difference in the content-area teachers' perceptions of the need for second language instructional strategies within the content-area classroom depending on how they were trained and when they were trained?

9. Is there a significant difference in the content-area teachers' perceptions concerning the implementation of second language instructional strategies within the content-area classroom depending on how they were trained and when they were trained?

\section{LIMITATIONS}

1. The study was limited to a sampling of teachers trained through either Miami-Dade County Public School's inservice training for content-area teachers or through enrollment in a university course.

2. The results of the data analysis are limited to providing information to Miami-Dade County's Bilingual Department for improvement and evaluation of the effectiveness of the inservice training for content-area teachers.

3. The study did not attempt to correlate the content-area teachers' use of second language strategies with the ESOL level of the students.

4. This study is limited by basing conclusions on self-reported data.

\section{ASSUMPTIONS}

1. Content-area teacher inservice training in instructional strategies for language minority students should be reflected in teachers' views of classroom practices. 2. Application of instructional strategies for language minority students can be identified through self-reported questionnaires. 
3. Responses from the questionnaires will provide information concerning current instructional practices, perceptions concerning teacher-training in second language strategies, and recommendations for future inservice training. 4. The sampling of teachers was representative of Miami-Dade County teachers trained through either the Miami-Dade County Public School's inservice training for content-area teachers or through enrollment in a university course.

\section{DEFINITION OF TERMS}

Perceived: the content-area teachers' perceptions regarding the effect of the mandated teacher training (Grant, 1991).

Effect: the extent to which the Consent Decree and the teacher training included therein has influenced teachers' perceptions and classroom instruction (Minaya-Rowe, 1991).

Mandated: refers to teacher training that was officially commanded, not voluntary (Dalton \& Moir, 1991).

Teacher training: inservice or college courses designed to provide teachers with an introduction to and practice in new methods, strategies, or techniques to be implemented in the classroom (Dade County Public Schools, 1995).

Content-area teachers: teachers of basic subject areas i.e. English, Math, Science, Social Studies, and Computer Literacy (Dade County Public Schools, 1995).

LEP students: Limited English Proficient students; students whose native language is other than English and who are in the process of acquiring English (Dade County Public Schools, 1995). 
Stipulated: items specified in the Consent Decree (LULAC et al.v. State Board of Education of Florida, 1990).

LULAC: League of Latin-American Citizens, a coalition that represents minority groups (Gomez-Quinones, 1990).

State Board of Education of Florida: the governing body which oversees education throughout the State (Florida Department of Education, 1995).

Consent Decree: document signed on August 14, 1990 in the United States District Court for the Southern District of Florida containing an agreement between LULAC et al. v. State Board of Education of Florida (1990) (Florida Department of Education, 1995).

Instructional practices: repertoire of methods, techniques, and strategies used by teachers in the classroom to individualize instruction to meet the needs of the students (Ambert \& Melendez, 1985). 


\section{CHAPTER TWO \\ REVIEW OF THE LITERATURE \\ INTRODUCTION}

In the review of the literature the researcher shall provide an overview of the history of legislative actions that led to the Consent Decree and an overview of the stipulations set forth in the Consent Decree. The researcher shall also provide an overview of Miami-Dade County Public Schools District LEP plan, developed in order to comply with the Consent Decree, especially as it affects teacher training including an overview of research on teacher training for language minority students.

\section{HISTORY OF LEGISLATIVE ACTION}

Politics and education are interrelated as education is continuously affected by public policy which in turn is influenced by public attitudes and values (Padilla, 1979). The Constitution of the United States does not guarantee language rights or education rights, but it does guarantee the right to equal protection of the law provided in the Equal Protection Clause of the Fourteenth Amendment to the United States Constitution. "This means that all citizens are to have equal access to opportunities for economic and social gain despite their racial or ethnic background, gender, age, or handicapping condition" (Bennet \& LeCompte, 1990, pp. 206-207). This has been the legal basis for the development of federal law that establishes the rights of language minority students and defines the obligations of school districts which serve those students (Ambert \& Melendez, 1985; Applewhite, 1979; Macias, 1979; Valle, et al. 1979). 
There have always been language minority students in the classroom; what has changed is the way the educational system has dealt with the new students (Brisk, 1982). Wiley (1993) stated that, "historically, decisions to suppress or restrict minority languages as well as decisions to impose dominant language and literacy policies have been linked to the attitudes of dominant groups towards subordinate groups" (p. 422). Towards the middle of the nineteenth century, a rising concern for the social welfare of the common person led educators such as Horace Mann to work for schooling which would be accessible to all children regardless of race, religion, or socioeconomic class. Mann's purpose was to promote American culture democratically (Schubert, 1986). English-Only laws began to appear in the 1870 's; however, local governments frequently turned a "blind eye" and schools in certain areas continued to teach in a language other than English (Brown, 1992, p. 4). Instruction in languages other than English in the schools continued to be tolerated until the end of the nineteenth century when various social, political, and economic concerns caused a shift in educational policy. At this time there occurred a major influx of immigrants from Southern, Central, and Eastern Europe. This influx, coupled with a rise in industrialization, urbanization, and growth in corporations, created social problems such as overcrowding, crime, and labor conflicts.

All of the aforementioned concerns caused the dominant group in society, largely those of northern and western European descent, to view these immigrants with trepidation. This trepidation engendered the Nativist and Americanization movements which sought to have the immigrants assimilate rapidly into 
mainstream American society in order to form a unified societal group. The dominant group, which was already established in the United States, saw the schools as a way to maintain a social order they felt was under siege (Apple, 1977; Ovando \& Collier, 1985). They sought to use the schools not only as a vehicle to impart American culture, but also as a mode to promote linguistic homogeneity by establishing a strong "Anglocentric" curriculum (Suzuki, 1984, p. 296), establishing the use of instruction only in English, and punishing the students for speaking in their native languages (Ambert \& Melendez, 1985; Brisk, 1982; Brown, 1992; Suzuki, 1984; Wiley, 1993).

This trend was transformed into the dominant ideology and has since influenced the development of the social institutions of this country. As stated by Bellack (1964), "the school must ... serve a multitude of ends and needs created by our society and our culture" (p. 222). This means that schools are a reflection of the national perspective held by society. Thus, at the beginning of the twentieth century, states began imposing English-Only instruction laws. Connecticut and Massachusetts enacted legislation requiring English to be the sole language of instruction in the 1870's. By 1923, English was mandatory in the educational systems of thirty-two states. Restraints on immigration that varied based on country of origin, an isolationist foreign policy, participation in two world wars, and the onset of the Depression contributed to this pattern of language dominance until after the Second World War. Until the 1960's, English remained the only language of instruction regardless of the native language of the student (Brisk, 1982). According to Ambert \& Melendez (1985), "before the 1960 's, it was assumed that uniform educational treatment was beneficial to all 
children" (p. 27). The idea of conforming to the mainstream, dominant cultural view remained the mainstay of the social institutions until the era of the Civil Rights movement in the 1960's. According to Appleton (1983), Gollnick and Chinn (1986), McCarthy (1990), Phillips (1988), Reagan (1985), and Suzuki (1984), social upheaval occurred in the 1960 's when minority groups reacted, at times violently, to what they felt was a system which promoted social inequality, discrimination, segregation, and a lack of equal educational opportunities for minorities. As a result of these social upheavals, there occurred an awareness of and an outcry against the cultural bias which was felt to exist in the schools. Thus, demands were advanced for ethnic studies, cultural awareness programs, educational reforms, and minority representation.

During this era, two pieces of legislation set the stage for subsequent rulings which provided access to equal educational opportunities for language minority students. First, a Supreme Court ruling which had nothing to do with language, but which motivated minority parents to become more active and provided them with the basis of equal protection was Brown v. Board of Education of Topeka (1954); it declared that segregating black students into separate educational facilities was unconstitutional and deprived them of equal educational opportunities (Ambert \& Melendez, 1985; Anderson \& Boyer, 1978; Appleton, 1983; Brown, 1992; Brown v. Board of Education, 1954). In addition, a piece of federal legislation which later provided the legal basis for subsequent legislation in favor of language minority student rights was Title VI of the Civil Rights Act of 1964; this required school districts receiving federal funding to guarantee that no student be excluded from participation in educational programs 
due to race, color, or national origin (Ambert \& Melendez, 1985; Florida Department of Education, 1995).

These pieces of legislation combined to exert political pressure on the government, resulting in the passage of the of the first major bilingual education bill - Title VII of the Elementary and Secondary Education Act, otherwise known as the Bilingual Education Act of 1968. This historic bill allocated funds for programs which would improve the education of limited English proficient students, legitimized bilingual education programs, and promoted research on bilingual education (Anderson \& Boyer, 1978; Brisk, 1982; Malakoff \& Hakuta, 1990; Matute-Bianchi, 1979). Although the act did not mandate bilingual education programs, it defined these programs as falling within federal educational policy, thus marking a change of policy towards language minorities and weakening the English-Only laws that existed in various states.

A memorandum issued by the Office of Civil Rights (OCR) on May 25, 1970 was instrumental in the policy development guiding bilingual education programs financially supported by the federal government. Subsequently, this memorandum became a cornerstone for future court decisions since it required compliance with Title VI of the Civil Rights Act when this act related to language minority students. The purpose of the memorandum was to clarify policy on issues related to school districts' responsibility to provide language minority children with the opportunity for an equal education. It specified school districts' responsibilities in the four areas described below. First, if the students' inability to speak English caused them to be excluded from participating effectively in the educational programs, then the district had to initiate steps to remedy the 
limitations of language. Second, school districts were not allowed to assign language minority students to special education classes based on English language limitations. Third, the limited language needs of these children had to be met as soon as possible so that any ability grouping or tracking system that was used did not become permanent. Fourth, school districts were responsible for providing information of school activities to language minority parents in their language. This memorandum clarified that simply providing all students with identical materials and instruction did not guarantee equal educational opportunity (Ambert \& Melendez, 1985; Florida Department of Education, 1995; Goonen, Angulo, \& Velez, 1983; Matute-Bianchi, 1979; Office of Civil Rights Memorandum, 1970).

Legislation through state and federal courts has been crucial in defining and establishing the educational rights of language minority students. Since the 1970's various significant cases have been litigated which have helped to clarify the process by which the needs of language minority students are met. Providing an overview may aid in a clearer understanding of the issues brought before the courts concerning the educational rights of limited English proficient students.

\section{Lau v. Nichols (1974)}

Even though the Office of Civil Rights Memorandum established the above stated guidelines in 1970 , the legal obligation of school districts to provide bilingual education programs went untested until the Supreme Court ruling in Lau v. Nichols (1974), which became the most important case in bilingual education and established the basis for future legislation. The Supreme Court based its decision in this case on the mandate of the Civil Rights Act. It claimed that 
simply providing the students with the same facilities, textbooks, teachers, and curriculum was not providing them equal educational opportunity, since students who did not comprehend English were effectively barred from receiving a meaningful education. The Supreme Court, although it did not stipulate any particular solution, mandated that school districts take affirmative steps to remedy the language limitations of language minority students in order to provide these students with access to the instructional program (Ambert \& Melendez, 1985; Appleton, 1983; Applewhite, 1979; Brisk, 1982; Center for Law \& Education; 1992; Florida Department of Education, 1995; Goonen et al., 1983; Hardaway, 1995; Lau v. Nichols, 1974; Malakoff \& Hakuta, 1990; Matute-Bianchi, 1979).

\section{Serna v. Portales Municipal School District (1974)}

This case was very similar to the Lau v. Nichols (1974) case. The District Court ruled that although an equal education was provided to the students, the Portales Municipal School District failed in adapting its programs to take into consideration the language limitations of its students. The verdict ordered the implementation of bilingual instruction. At first, the District Court based its decision on the United States Constitution, indicating a violation of the Equal Protection clause. However, in light of the Lau v. Nichols (1974) decision, the District Court's decision in the Serna v. Portales (1974) case was upheld as a violation of the Civil Rights Act - Title VI. This ruling was significant in that it established bilingual education programs as a specific remedy to meet the educational needs of language minority students (Ambert \& Melendez, 1985; Appleton, 1983; Applewhite, 1979; Florida Department of Education, 1995; Goonen et al., 1983; Matute-Bianchi, 1979; Serna v. Portales, 1974). 


\section{Equal Educational Opportunities Act (1974)}

Congress codified the Supreme Court ruling in Lau v. Nichols (1974) into the Equal Educational Opportunities Act (EEOA) of 1974. This act extends the Lau v. Nichols (1974) decision to all public school districts. In section 1703(f), the act states that equal educational opportunity cannot be denied to anyone based on race, color, sex, or national origin by the failure of the educational institution to take appropriate measures to remedy language limitations which impede the students' equal participation in its instructional programs. (Ambert \& Melendez, 1985; Center for Law \& Education, 1992; Equal Educational Opportunities Act, 1974; Florida Department of Education, 1995; Malakoff \& Hakuta, 1990).

\section{ASPIRA of New York, Inc. v. Board of Education of New York (1974)}

The effects of the decision in Lau v. Nichols (1974) and Serna v. Portales (1974) were evident in the ASPIRA v. Board of Education of New York (1974) case when, in consideration of the legal mandates imposed on school districts, a consent decree was signed to obligate the School Board of Education of New York to provide bilingual instruction for all children whose language limitations in English prevented them from participating effectively in the learning process. This ASPIRA Consent Decree also included agreements on the utilization, development, and distribution of suitable materials and assessments as well as the hiring, training, or retraining of staff. The court ruling limited participation in the bilingual program to those students who demonstrated stronger language skills in the native language than in English (Ambert \& Melendez, 1985; Applewhite, 1979; ASPIRA of New York, Inc. $\mathrm{v}$. Board of Education of New York, 1974; Goonen et al., 1983; Matute-Bianchi, 1979). 


\section{Lau Remedies (1975)}

Since the Supreme Court did not stipulate any particular solution or program in the Lau V. Nichols (1974) case, the Office of Civil Rights formed a task force to set guidelines to implement the Lau v. Nichols (1974) decision, commonly known as the Lau Remedies. These guidelines cover identification and assessment procedures, appropriate educational programs, teacher qualifications, mainstreaming criteria for limited English proficient students, appropriate communication with parents, and evaluation procedures. Even though the Lau Remedies were never established as formal regulations, the Department of Housing, Education, and Welfare began to treat them as such and they have become the basis for the Office of Civil Rights enforcement activities and have been cited by federal courts in language minority cases (Brisk, 1982; Florida Department of Education, 1995; Goonen et al. 1983; Malakoff \& Hakuta, 1990).

\section{Rios v.Reed (1977)}

The effects of previous court decisions related to equal educational opportunity were visible in the Rios V. Reed (1977) ruling. The District Court ruled that the Patchoque-Medford School District in Long Island had to provide student school records to be used in determining if the bilingual education programs being offered were effective in promoting the students' English language growth. Token programs that did not benefit the students could not be considered to be in compliance with Lau v. Nichols (1974) (Ambert \& Melendez, 1985; Applewhite, 1979; Florida Department of Education, 1995; Goonen et al., 1983; Rios v. Reed, 1977). 


\section{Ramos v. La Fontaine (1976)}

Various class action suits filed on behalf of language minority students cited the lack of equal educational opportunity due to either the absence of bilingual education programs or inadequate or inappropriate programs. A consent decree approved on June 5, 1978 in the Ramos V. La Fontaine (1976) case was specific in its mandates. They include identification of students through survey and testing, parental approval for participation, assessment of staff's language ability, recruitment of staff to guarantee suitable services, development of a parent participation plan, equal access to curriculum requirements, and development of an organizational structure for the bilingual program (Ambert \& Melendez, 1985; Ramos v. La Fontaine, 1976).

\section{Castaneda y. Pickard (1981)}

The preceding cases show that there was confusion and concern regarding what constituted appropriate measures taken to remedy the language limitations of students as stipulated in the Equal Education Opportunity Act. The case of Castaneda v. Pickard (1981) was significant in that it created a framework for determining if a school district was implementing appropriate measures. The Court designed an assessment that focused on three areas to clarify the EEOA's requirements for appropriate measures. First, a school system should implement a program based on sound educational theory. Second, a school system could not be said to be taking appropriate measures if the program was based on sound theory, but there was no follow-up with implementation to convert the theory into reality. Third, a school system could not be said to be taking appropriate measures if they continued to use a program that, after a reasonable trial period, 
failed to produce the specified results, even if the programs were based on sound theory and adequate techniques of implementation were used.

The Court did not prescribe a specific structure or strategies for a program, but did focus on the results. School systems were informed that it was not enough to provide intensive English; the students also needed assistance in the other areas of curriculum affected by their language limitations. The school was free to determine the manner in which to remediate this situation as long as the programs implemented enabled the students to attain equal educational access to standard programs in a reasonable length of time after entering the school (Castaneda v. Pickard, 1981; Center for Law \& Education, 1992; Florida Department of Education, 1995).

\section{Office of Civil Rights (OCR) Standards for Title VI Compliance (1985)}

Like the Lau Remedies, the current guidelines for Title VI compliance have not been established as formal regulations. These guidelines do not mandate a specific educational approach; however, they stipulate that if language minority students are unable to participate in the regular school program, then an alternative program must be provided. In reference to the effectiveness of a program, the guidelines present a three part assessment similar to that set forth in Castaneda v. Pickard (1981) (Florida Department of Education, 1995).

\section{LULAC et al v. State Board of Education of Florida (1990)}

The rights of language minority students have been established through federal and state legislation, administrative policy decisions, and litigation. However, it can also be seen that even though these rights were initially established in 1968 through the Bilingual Education Act, continuing litigation has 
been necessary to enforce, expand and clarify those rights. That was the focus of LULAC et al. v. State Board of Education of Florida (1990). The settlement resulted in the signing of a consent decree on August 14, 1990, which not only affected the school district of Osceola County, Florida where the suit originated, but also all of the school districts in the state of Florida that must comply with its stipulations. The suit was brought by LULAC. LULAC was initially a conservative Mexican-American group founded in 1929, that, due to political, social, and economic factors, went through a shift in emphasis from moderate to activist to centrist, eventually becoming a pan-Latino organization. LULAC used the judicial system as an effective means to assert the rights of limited English proficient students (Garcia \& Garza, 1977; Gomez-Quinones, 1990). The suit was initiated due to a dispute concerning the State Board of Education of Florida's compliance with its legal obligations under federal and state law. The State of Florida did not have statewide educational standards governing the instruction of limited English proficient students in the State Statutes (LULAC et al. v. State Board of Education of Florida, 1990).

The Consent Decree specifically addressed six areas of emphasis. The first area of focus is the identification and assessment of students. The Consent Decree defines specific terms and focuses on initial identification through a survey, assessment of English language proficiency through both oral and written assessments, assessment in basic subject areas to develop appropriate instructional programs, stipulations for classification as LEP, and stipulations for reclassification as English proficient. It provides for monitoring of students reclassified as English proficient to ensure parity of participation (Broward 
County Public Schools, 1992; LULAC et al. V. State Board of Education of Florida, 1990).

The second area of focus is equal access to appropriate programming. The Consent Decree presents the principle that each LEP student is entitled to both intensive English instruction and instruction in basic subject areas that are understandable given the student's level of English proficiency. It further stated that these subjects must be equal in amount, scope, sequence, and quality to those offered English proficient students. It stipulated that the State must approve the districts' LEP plans for their proposed procedures and methodologies for serving LEP students. The Consent Decree delineated services to be provided in basic English for Speakers of Other Languages (ESOL) instruction and also in instruction in basic subject areas provided in either English or the home language of the student. Both basic ESOL instruction and instruction in basic subject areas in English are to be taught by qualified personnel using ESOL strategies. In the absence of trained personnel, a plan for interim measures must be provided stating steps being taken to comply. The Consent Decree sets up Parent Leadership Councils for the involvement of LEP students' parents (Broward County Public Schools, 1992; LULAC et al. v. State Board of Education of Florida, 1990).

The third area of focus is equal access to all educational programs. The Consent Decree mandated equal access for LEP students to any programs or supportive services provided by the school or district. It also stipulated that communication with the parents be undertaken in their native language whenever possible and that no LEP student be disciplined for using his/her native language 
(Broward County Public Schools, 1992; LULAC et al. V. State Board of Florida, 1990).

The fourth area of focus is that of personnel. The Consent Decree specifically stipulated the training to be undertaken by teachers who are assigned a LEP student. Teachers of Basic ESOL instruction were to take 300 hours of inservice training or five college courses and score 220 on the Test of Spoken English which assesses proficiency in English, unless they fell under the "Grandfathering Clause". This clause stipulated that teachers who could provide documentation of successful teaching of Basic ESOL to LEP students prior to the 1990 - 1991 school year would only need sixty hours of inservice training or a three-credit college course. Teachers of basic subject areas where instruction is provided in either English or in the home language of the student are to take sixty hours of inservice training or a three-credit college course. Home language instruction teachers also have to demonstrate proficiency in the home language. Teachers in areas other than basic subjects are to take eighteen hours of inservice training or a three-credit college course. A specified time period is provided for completion of training requirements (Broward County Public Schools, 1992; LULAC et al.v. State Board of Education of Florida, 1990).

The fifth area of focus is that of monitoring. The Consent Decree mandated that the Florida Department of Education will regularly monitor local school districts to verify compliance with the provisions of the agreement, equal access, and program effectiveness (Broward County Public Schools, 1992; LULAC et al. v. State Board of Education of Florida, 1991). 
The sixth area of focus is that of outcome measures. The Consent Decree stated that the Florida Department of Education will develop an evaluation system containing outcome measures for assessment of compliance with Federal and State law in reference to LEP students. The evaluation system will focus on the area of equal access to verify LEP student participation in all programs offered by the school district and on the area of program effectiveness using as indicator whether LEP students are acquiring English language skills in a reasonable time period (Broward County Public Schools, 1992; LULAC et al. V. State Board of Education of Florida, 1990).

\section{MIAMI-DADE COUNTY DISTRICT LEP PLAN}

The Consent Decree is extremely prescriptive in detailing the services that a school district must provide to LEP students. The Consent Decree requires that every school district in the State write and submit to the Florida Department of Education a District LEP Plan which specifies the steps the district will take to ensure that they are in compliance with all areas of the Consent Decree. Miami-Dade County's District LEP Plan for LEP students is made up of nineteen sections which adhere to an outline provided by the Florida Department of Education as a guide in preparing the plan. The sections are based on the areas of focus covered by the Consent Decree and provide the step-by-step procedure the district will follow in complying with the Consent Decree. The nineteen sections are titled as follows:

Section 1 - Initial Identification Procedures

Section 2 - Assessment Procedures/Steps to Determine Eligibility for Appropriate Services 
Section 3 - Appropriate Programming for General Education Students Section 4 - On-going Procedures for Evaluating Appropriateness of Programs for Individual Students

Section 5 - Procedures for Reevaluation for Annual Extension of Program After the Basic Three Year Period

Section 6 - Procedures for Exiting Students from LEP Services

Section 7 - Procedures to Comply with Post Program Review/Monitoring Requirements

Section 8 - Procedures to Provide Access to Home Language Services in Schools with 15 or More LEP Students of the Same Home Language Background Section 9 - Procedures to Ensure Equal Access to All LEP Students, Appropriate LEP Services, and Understandable Instruction in Categorical and Other Programs/Services

Section 10 - District and School Level Procedures to Provide Understandable Home/School Communication

Section 11 - Procedure to Disseminate Information to Schools, Students, and Parents Regarding Assurance that No National Origin Minority or LEP Students Be Subjected to Any Disciplinary Action Because of Their Use of a Language Other Than English

Section 12 - Procedures to Coordinate and to Monitor Collection and Accuracy of Student Data

Section 13 - Procedures to Establish the LEP Parent Leadership Councils Section 14 - Plan to Monitor Program Compliance by Individual, Schools, Programs, and/or District Wide Services 
Section 15 - Personnel - Certification Requirements

Section 16 - Personnel - Inservice Requirements

Section 17 - Inservice Training Programs - Standards

Section 18 - Projected Insurance Requirements During Plan Duration in Each Inservice Category

Section 19 - Monitoring Procedures Related to Inservice Training (Dade County Public Schools, 1995)

Sections 15, 16, and 17 of the above Miami-Dade County District LEP Plan specify the requirements and standards set forth for teachers in meeting the stipulations for training required by the Consent Decree.

Since the focus of this study is to explore the teachers' perceptions of the level of implementation of the second language strategies acquired through the teacher training of content-area teachers, the next section provides an overview of teachers' beliefs as these influence perceptions. It also provides a closer look at teacher training in general and specifically for language minority students. This section highlights the difficulty of sustaining change efforts as it relates to teacher training.

\section{TEACHER TRAINING}

As this study is concerned with teachers' perceptions concerning the effect that compliance with the mandated training for content-area teachers has had on their instructional practices, it seems appropriate to focus on teachers' beliefs as they influence perceptions before focusing on teacher training. A focus on teachers' perceptions as a reflection of beliefs, was described by Richardson (1994). "Beliefs are an individual's understandings of the world and the way it 
works or should work, may be consciously or unconsciously held, and guide one's actions" (p. 91). Perception as defined in the Scribner-Bantam English Dictionary (1991) is "the act or faculty of perceiving, mental impression" (p. 671), whereas belief is defined as "opinion, an act of the mind, the mental assent to something as true" (p. 86). Therefore, as can be deduced, one's perception's are influenced by one's beliefs. Perceptions and beliefs appear to be interrelated. Thus, focusing on teachers' beliefs can shed light on how teachers' perceptions are formed. According to Tatto (1998):

Purposes of education may shape teachers' beliefs about what is appropriate in teaching and teachers' conceptions about their professional role. Conceptions of their role may in turn, shape their teaching practice. Societal mechanisms including the media, socialization processes from childhood to adulthood, and experiences with schooling may heavily influence ... views (pp. 66-67).

In other words, teachers' beliefs and in turn their perceptions are shaped not only by the view taken of the purpose of schooling but by societal influences. It is important to focus on teachers' beliefs and consequently their perceptions because, although these tend to vary from teacher to teacher, they will have an effect on teacher behavior in the classroom and how teachers react to policy changes (Anders \& Richardson, 1994; Buchmann, 1986; Prawat, 1992).

Policy changes, no matter where they originate, are meant to be implemented by the teacher within the classroom and training for teachers concerning these policy changes must take into account the teachers' beliefs. As 
stated by Richardson (1994):

Teacher beliefs are an important consideration in understanding classroom practices, and therefore in conducting staff development programs designed to alter teachers' practices. If beliefs are related to practices, and more particularly, if belief drives practices, staff development that focuses solely on teaching practices may not be successful in effecting change, unless the teachers' beliefs and the theories underlying the practices are also explored (p. 90).

Evaluating teachers' perceptions of the impact of teacher training within the classroom is an aspect of monitoring training program effectiveness which needs to be studied. This is an area of concern for a variety of reasons. The first reason is expressed by Valle et al. (1979) who state, "court intervention in educational matters may serve to alienate many teachers to the extent that the merits of court-ordered programs become muddled" (p. 76). In other words, training requirements mandated through legislation might be considered by the teachers to be an unwarranted imposition and thus affect these teachers' perceptions of the benefits of the training. "Professionally-oriented teachers oppose external mandates pertaining to classroom functions, for their culture holds that they are the educational experts" (Schwartz, 1991, p. 79).

At this point, it seems pertinent to mention the current push for educational reform concerning the development of standards for the teaching of different subject areas and the national certification of teachers. The Delaware 
State Education Association (1996b) states as follows:

In 1987, the National Board for Professional Teaching Standards was created as a nonprofit, nonpartisan, nongovernmental organization whose mission is to establish high and rigorous standards for what accomplished teachers should know and be able to do, to develop and operate a national voluntary system to assess and certify teachers who meet these standards and to advance related education reforms for the purpose of improving student learning in American schools (p. 1 ).

Even though these standards form part of the push for educational reform, they are viewed in a different light than external mandates legislating training. First of all, the achievement of these standards is not mandatory but voluntary. Second, these standards are not being developed solely by those located beyond the school site but by classroom teachers themselves. Finally, these standards serve to validate professionally-oriented teachers' perceptions that they are experts in their field.

Teachers believe they already possess the knowledge base, the teaching skills, and the professional expertise to know what functions well in their domain-the classroom. Nevertheless, legislative mandates are typically made at what Klein (1991a) refers to as the "formal level" (p. 28), which encompasses all who have the power to impose or suggest changes within the domain of the classroom, yet who are located beyond the school site. However, the decisions made at other levels must go through the teachers in order to be implemented and it is simplistic to think that the changes will take place automatically (Klein, 
1991a). According to Chin and Benne (1985) there is some resistance to change. They state:

People must learn to learn from their experiences if self-directed change is to be maintained and continued. Frequently, people have learned to defend against the potential lessons of experience when these threaten existing equilibrium, whether in the person or in the social system (p. 36). In other words, initially people resist change as they attempt to maintain their equilibrium. Change is not automatic, it is a process.

According to Mercado and Sapiens (1992) and Minaya-Rowe (1991), professional development imposed from above on the teachers may not effect the desired change within the classroom unless there exists a common ground of concern between the formal level and the instructional level and an internal motivation to change is fostered in the individual. According to Kyriacou (1996):

Teachers need periods in which to develop, consolidate, and refine what they do. Change can act as an important catalyst for a critical appraisal of established practice. But if change occurs too frequently, too quickly and is largely imposed on teachers without arising naturally from teachers' own concerns about their practice, it can undermine the quality of the education teachers are trying to provide (p. 7).

Therefore, personal relevance, involvement in the process of professional development, a clear view of the connection between the training and the benefits to students, and compatibility of the recommendations to teachers' educational philosophy are all factors which might have an effect on the implementation of mandated training (Christensen \& Burke, 1982; Fullan, 1993; Holly, 1982; 
Lieberman \& Miller, 1981; Mohlman, Coladarci, \& Gage, 1982; Wood, McQuarrie, \& Thompson, 1982). Consequently, teachers' perceptions of the benefits of training might be affected when this training is imposed upon them from above without taking into consideration what teachers feel is their realm of professional expertise.

This leads one to the second aspect of concern, which is expressed by Joyce and Showers (cited in Hamayan, 1990) "research on staff development has indicated that the presentation of theory alone in inservice programs guarantees that only $5-10 \%$ of the teachers will apply the new skills in their classroom" (p. 16). According to Goldenberg and Gallimore (1991), Joyce and Showers (1982), Joyce, Showers, and Rolheiser-Bennet (1987), Mohlman et al. (1982), and Sparks (1983), presentations given through quick staff development workshops are insufficient to assure long-lasting changes. The "rhetoric of instructional innovation far surpasses the reality of classroom change" (Goldenburg \& Gallimore, 1991, p. 69) "since many reforms seldom go beyond getting adopted as policy" (Cuban, 1990, p. 9). Effective staff development should take into account that change is a complex process not achieved quickly.

Research on staff development indicates there are certain staff development practices which seem to be effective in promoting the implementation of new approaches to teaching. First of all, staff development should incorporate current knowledge based on research in order for teachers to develop both a conceptual understanding of learning processes and further expertise in learning processes (Delaware State Education Association, 1996a; Goldenberg \& Gallimore, 1991; Leiberman, 1994; Richardson, 1998). Next, staff 
development should provide for time for reflection where teachers can explore their own practices, learn from their experiences, and determine their own direction of change ( Harris, 1997; Lieberman, 1994; Microsoft, 1998; Richardson, 1998). Furthermore, staff development should provide participants with opportunities to share their experiences and techniques, to practice and receive feedback from peers as they develop the new strategies in order to build a sense of collegiality (Fullan, 1992; Goldenberg \& Gallimore, 1991; Lieberman, 1994; Minaya-Rowe, 1991; Richardson \& Hamilton, 1994). In addition, staff development should focus not on only on training but on providing a chance to learn, practice, consult, and assess within the routine organization of the participant's situation so that knowledge can become personally owned through action (Harris, 1997). Finally staff development should provide for follow-up or coaching where the teachers are helped to incorporate the new teaching approach into their repertoire of skills within their individual teaching situations (Fullan, 1992; Microsoft, 1998; "The Policy Dilemma", 1994). These staff development practices are designed to involve the teachers in a participatory mode in which the new approaches are made personally relevant.

There is concern that continued teacher training, especially if it is mandated, might not have the effect in the classroom that was intended. "Teachers and site administrators must be directly involved in proposals for change and must develop ownership of them if they are to become a reality, even those emanating from powerful sources such as the state ... Even teachers who may be supportive of state-mandated changes, or at least not resistant to them, do not necessarily implement them in their classrooms as planned" (Klein, 1991b, p. 
222). In other words, teachers will comply with the mandatory training; however, that does not guarantee that learning new instructional practices will effect changes in their everyday practice. According to Chin and Benne (1995):

Some of the difficulty with the use of political institutions to effect changes arises from an overestimation by change agents of the capability of political action to effect changes in practice. When the law is passed, the administrative ruling announced, or the judicial decision handed down legitimizing some new policy or illegitimizing some traditional practice, change agents who have worked for the law, ruling, or decision frequently assume that the desired change has been made. Actually, all that has been done is to bring the force of legitimacy behind some envisioned change. The processes of re-education of persons who are to conduct themselves in new ways still have to be carried out. And the new conduct often requires new knowledge, new skills, new attitudes, and new value orientations (p. 41).

This brings up the final area of concem, which is that "there is little evidence that practice is substantially changing ... it appears likely that a significant gap may exist between prevalent conceptions of effective instructional strategies for language minority students and actual practice" (Mercado \& Sapiens, 1992, p. 6). In other words, although teachers might have been exposed to new instructional practices that would be beneficial for the language minority students, the implementation of these practices might not be occurring in the classroom. Joyce and Showers (1982) pointed out that "the development of skill by itself does not ensure transfer; relatively few teachers, having obtained skill in 
a new approach, will then transfer that skill into their active repertoire and use the new approach regularly" (p. 5).

Transferring the new skill into active use would signify change and change is at times not easily accomplished. Change creates an imbalance in a set routine or conceptualization. Implementing a new skill means having to think and act differently, which causes discomfort, as initially the new skill might not easily adapt to existing practices (Joyce \& Showers, 1980; Joyce \& Showers, 1982). As discussed previously, according to Chin and Benne (1985), there is some resistance to change. In other words, people initially tend to resist change as they strive to maintain their set routine, their sense of balance. However, although there is resistance to change this does not signify that change is impossible. As stated by Prawat (1992):

Getting people to change beliefs, especially intuitively reasonable ones, is a difficult proposition. Recent research on the conceptual change process indicates that several criteria must be met: First, individuals must be dissatisfied with their existing beliefs in some way; second, they must find the alternatives both intelligible and useful in extending their understanding to new situations; third, they must figure out some way to connect the new belief with their earlier conceptions (p. 357). Therefore, change is not immediate; it is a process. There must be an awareness of the need to change, a clear and specific understanding of the innovation and what it can accomplish, which would make the effort of implementing it worthwhile and also a blending of the new practice with the teacher's current mode of presentation (Fullan, 1992; Fullan, 1993; Joyce et al., 
1987; Lieberman \& Miller, 1981; Mohlman et al., 1982; Sparks, 1983). Based on the prior discussion, one should be concerned with the strategies to be used in effecting a change in a human system. One such group of strategies, discussed in the literature on change theory, is known as normative-reeducative. According to Chin and Benne (1985):

These strategies build upon assumptions about human motivation... Change in a pattern of practice or action, ... will occur only as the persons involved are brought to change their normative orientations to old patterns and develop commitments to new ones. And changes in normative orientations involve changes in attitudes, values, skills, and significant relationships not just changes in knowledge, information, or intellectual rationales for action and practice (p. 23).

In other words, simply providing information and reasons for a change does not signify that the change will take place if the person is not involved in the change process. Lewin, (cited in Chin \& Benne, 1985), indicated that "man must participate in his own re-education if he is to be re-educated at all. And re-education is a normative change as well as a cognitive and perceptual change" (p. 31). Consequently, not only must teachers have access to the new information, but they must also go through a change process in order for implementation within the classroom to occur on a regular basis. Since change in teacher behavior is needed to fully implement the new procedures, there is a need to follow-up on teacher training for content-area teachers of language minority students in order to verify how it is reflected in the classroom. Ambert and Melendez (1985) make an important point when they state: 
It is clear that if inservice training is to have real value, it must prepare teachers to apply new methods and techniques, use new materials and technology, adapt and utilize new concepts in the classroom. This can only be achieved through inservice training that is designed to respond to clearly identified and articulate needs in a process that involves all the parties with a stake in the outcome (p. 283).

Therefore, teacher training should take into consideration not only the needs of the students, but also those of the teachers as well. Staff development should occur as a collaborative process.

The number of language minority students is rising; consequently, an increasing number of teachers can no longer assume that all students in the classroom understand English (Zehler, 1994). As the diversity of the student body increases, teacher training must be redefined. Teachers need to have the necessary knowledge and skills to assume responsibility for addressing the academic demands of linguistically different students (Blanco, 1977; Clark, 1990; Dalton \& Moir, 1991; Goodlad, 1991; Mercado \& Sapiens, 1992; Zehler, 1994). The assumption exists that the academic training of language minority students is the responsibility of specialized bilingual personnel and not the mainstream teacher; however, the ever-increasing population of language minority students in the classroom indicates the need for teachers to redefine their approach in working in a multilingual setting. "Whatever the future holds, all teachers will require continuing professional education in order to adjust to new tasks and demands" (Kyriacou, 1996, p.11). The skills and responsibilities of the mainstream teachers need to be restructured as they face a growing number of 
students who are not only striving to learn English, but who are also struggling to keep up with content-area mastery as a requisite for academic success and equal educational opportunity.

A discussion of what instructional strategies should be included in teacher training for working with language minority students follows. In order for language minority students, who have yet to achieve full proficiency in English, to progress in content-area classes, instructional strategies should be implemented which facilitate their learning (Christian, Spanos, Crandall, Simich-Dudgeon, \& Willetts, 1990; Clark, 1990; Grundy, 1992; Mercado \& Sapiens, 1992; Zehler, 1994). Teacher training should familiarize the teacher with instructional strategies such as:

-Establishing a classroom that is accepting of the LEP student with a predictable routine that makes them feel safe;

-Contextualizing learning activities through the use of extralinguistic cues; -Activating students' prior knowledge to establish familiarity with context; -Modifying language through pacing and repetition; -Providing tasks that allow students to actively participate and provide interaction thus maximizing opportunities for using language to communicate; -Involving students in a cooperative learning environment that promotes both social and academic language; -Presenting central concepts through themes; -Developing reading/writing strategies through mapping, brainstorming, process writing, and so on; 
-Incorporating cultural referents and diversity into content area to provide all students with the opportunity to recognize different cultural perspectives; and, -Communicating and maintaining high expectations of all students (Christian et al., 1990; Clark, 1990; Grundy, 1992; Mercado \& Sapiens, 1992; Zehler, 1994).

The Miami-Dade County District LEP Plan stipulates the training required for content-area teachers who work with language minority students. Inservice requirements for teachers of basic subject areas include completion of a course entitled "ESOL Issues and Strategies", which can be taken through the Teacher Education Center or through a university. The District maintains computerized records and original paperwork detailing all training provided to each individual. As of February 20, 1996 Miami-Dade County had 7,787 teachers already trained and needed to train at least 3,440 teachers during the time period of 1995-1998 (Dade County Public Schools, 1996).

Grant (1991) states that there are five different approaches that educators take in dealing with diversity in the schools. According to Grant (1991):

The first of these approaches, Teaching the Exceptional and Culturally Different, helps fit people into the existing social structure and culture. Dominant traditional educational aims are taught by building bridges between the students and the school. The curriculum is made relevant to the students' backgrounds, instruction builds on students' learning styles, and is adapted to their skill levels. Teaching culturally different or exceptional children accommodates such students by altering regular 
teaching strategies to match student learning styles through the use of culturally relevant materials or remedial teaching strategies (p. 434). The teacher training course implemented in Miami-Dade County Public Schools follows the aforementioned approach. This training was set up to comply with stipulations set forth in the LULAC et al. v. State Board of Education of Florida Consent Decree of 1990.

The course required for teachers of basic subject areas, "ESOL Issues and Strategies," includes the following content: legislative requirements, functions and levels of ESOL, language acquisition theory, guidelines for programs, adaptation of materials and lessons for LEP students, alternative assessments for LEP students, presentations of lessons using ESOL strategies, and selected readings (Dade County Public Schools, 1995). This course is based on research which indicates that the classroom teacher can incorporate second language strategies in the content-area, thus adapting language, materials, and the presentation of information so that it is more comprehensible to language minority students (Ambert \& Melendez, 1985; Christian et al., 1990; Scarcella, 1990).

Content area teachers are exposed to instructional strategies and methods that facilitate learning for language minority students through this mandatory training; nonetheless, concern remains as to whether this mandatory training has an impact on instructional practices in the classroom. Mercado and Sapiens (1992) voice this concern succinctly when they state, "it is important to note that professional development cannot be imposed from the outside; the need and desire for change must grow from within each individual" (p. 9). Does the 
legislated teacher inservice training fuel that need and desire? This is an interesting question and according to Kyriacou (1996):

For many teachers, the opportunity to develop new skills provides them with a chance to rejuvenate their teaching careers. ... The opportunity to take on new roles and tasks, and to develop new approaches to their work, offers teachers, at various points in their career, welcome challenges that help to prevent a sense of stagnation occurring" (p. 9).

\section{SUMMARY}

In conclusion, there appear to be many aspects involved in studying teachers' perceptions of the effect that the teacher training mandated through the Consent Decree has had on instructional practices for language minority students within the classroom. The review of literature led this researcher into the areas of legislative action leading up to and including the Consent Decree, societal perspectives, educational rights and strategies for language minority students, Miami-Dade County Public Schools District LEP plan and teacher training, staff development and implementation, the process of change and the application of new strategies in actual practice. Therefore, a need was perceived for initial follow-up data collection in regard to the perceptions of teachers' relating to the effectiveness of teacher training on the content-area teachers' instructional practices. The collection of this data would provide information to those involved in future staff development efforts in this area. 


\section{CHAPTER THREE \\ METHODOLOGY AND PROCEDURES}

This chapter will present the methodology and procedures involved in this study. The conceptualization, research rationale, population, sample, design, data collection, and analysis used in this study will be discussed.

\section{CONCEPTUALIZATION}

The conceptualization of this study had its origin in this researcher's participation as a teacher trainer with Miami-Dade County Public School teachers enrolled in courses designed to meet the stipulations set forth in the Consent Decree. This researcher participated as a teacher trainer in courses offered at both Florida International University and by the Miami-Dade County Public Schools. In both instances, this researcher was intrigued by the comments the participants expressed concerning the mandatory nature of the training. As discussed in the review of literature, legislatively mandated teacher training requirements may be perceived by some teachers as an unwarranted imposition, thus affecting their perceptions regarding the training benefits. The review of the literature also points out a lack of studies specifically addressing the effectiveness of teacher training as it relates to language minority students. Consequently, this researcher decided to investigate content-area teachers' perceptions of the effect of the mandated training for content-area teachers of LEP students on their instructional practices in Miami-Dade County Public School classrooms.

\section{RESEARCH RATIONALE}

The purpose of this study was to explore the content-area teachers' perceptions of the effect that compliance with the mandated training for 
content-area teachers of LEP students has had on their instructional practices within the classroom. The objective of this research effort was to collect "information relevant to the evaluation of the effects of a program of action, for instance, to determine the impact of a new program of teaching in a school system" (Sonquist \& Dunkelberg, 1977, p. 1) and to gather "attitudinal and opinion data concerning the graduates' (teachers') perceptions of the adequacy of their training" (Gay, 1981, p. 158). To this end, it was decided to survey teachers who had completed the mandatory training. Fowler (1993) stated:

There are three potential properties of data from a properly done survey that may make them preferable to data from other sources:

1. Probability sampling enables one to have confidence that the sample is not a biased one and to estimate how precise the data are likely to be.

2. Standardized measurement that is consistent across all respondents ensures that one has comparable information about everyone involved in the survey.

3. A special-purpose survey may be the only way to ensure that all the data needed for a given analysis are available and can be related (p. 3).

In addition, the topic of inquiry was believed to be of a sensitive nature since it dealt with attitudes towards the training and changes in instructional practices required by the Consent Decree. Mandatory changes in instructional practices must be implemented; yet, these changes may be resisted by teachers who believe they already possess the knowledge base, the teaching skills, and the professional 
expertise to know what functions well in their classroom. These teachers may not be willing to admit in person that they are reluctant to implement the mandatory change (Klein, 1991). Studies in the past twenty years have compared the results of various data collection strategies such as personal interviews, telephone interviews, and self-administered procedures (Fowler, 1993). Some researchers have argued that "self-administered procedures are thought to be best because the respondent does not have to admit directly to an interviewer a socially undesirable or negatively valued characteristic or behavior ... it is very unusual for self-administered forms not to be at least as good as the other methods at eliciting responses that may be socially sensitive or embarrassing (Fowler, 1993, p. 58). Consequently based on the purpose of the inquiry and the properties of surveys, the choice was made to collect and analyze quantitative data.

\section{DEFINITION OF THE POPULATION}

The population for this study consisted of all elementary, middle, and high school content-area teachers currently employed in the Miami-Dade County Public Schools who have taken the mandatory teacher training course stipulated by the Consent Decree.

\section{DEFINITION OF THE SAMPLE}

Miami-Dade County Public Schools maintains a computerized record of all the content-area teachers who have been trained and their current work location. A computer generated printout of these teachers was available through the Systems and Programming Services of the Office of Information Technology. From this population, a sample of 400 subjects was randomly selected using the stratified sampling technique. According to Gay (1981), "stratified sampling is 
the process of selecting a sample in such a way that identified subgroups in the population are represented in the sample in the same proportion that they exist in the population" (p. 90). This type of random sampling technique was chosen because the researcher "wanted to guarantee appropriate representation of teaching level in the sample of teachers" (Gay, 1981, p. 92). Out of the 400 subjects selected, 244 , or $61 \%$, were elementary school teachers, 80 , or $20 \%$, were middle school teachers, and 76 , or $19 \%$, were high school teachers. This guaranteed proportional representation of these subgroups in the sample.

\section{QUANTITATIVE DESCRIPTIVE DESIGN}

The purpose of this study was to explore the content-area teachers' perceptions of the effect that compliance with the mandated training for content-area teachers of LEP students has had on their instructional practices within the classroom. The decision was made to survey the teachers who had completed the mandatory training. According to Gay (1981):

descriptive studies are concerned with the assessment of attitudes, opinions, demographic information, conditions, and procedures. Descriptive data are usually collected through a questionnaire survey, interview, or observation. ... Frequently, since one is generally asking questions that have not been asked before, or seeking information that is not already available, a descriptive study requires the development of an instrument appropriate for obtaining the desired information (pp. 53-154). A researcher-developed survey instrument, which consisted of two sections was designed for this study. The first section contained eleven questions aimed at identifying demographic information about the respondent. The second 
section contained thirty-two statements which sought to ascertain the content-area teachers' perceptions concerning the Consent Decree, teacher training, and implementation of second language strategies within the content area classroom.

In order to establish construct validity, the statements in the second section were grouped according to one of the first three subsidiary questions of this research study. Referring to the first subsidiary question, items twelve through twenty-one focused on the content-area teachers' perceptions concerning the LEP students' need of second language instructional strategies within the content-area classroom. As stated in the review of literature, the question arises as to what the content-area teachers' perceptions are regarding the teacher training mandated by the Consent Decree and do these perceptions affect the actual application of the methods and strategies shown effective with the LEP student. Grant (1991) stated, "it is important that research go beyond concepts of changing teacher beliefs and behaviors about working with diverse students. It is also important to understand how these teachers' beliefs and behaviors impact on classroom management and instructional preparation" (p. 450).

Referring to the second subsidiary question, items twenty-two through thirty-two focused on the content-area teachers' perceptions concerning the teacher training requirement mandated in the Consent Decree. As presented in the review of the literature, training requirements mandated through legislation might be considered by the teachers to be an unwarranted imposition and thus affect these teachers' perceptions of the benefits of the training. According to Schwartz (1991), "professionally-oriented teachers oppose external mandates 
pertaining to classroom functions, for their culture holds that they are the educational experts" (p. 179).

Finally, referring to the third subsidiary question, items thirty-three through forty-three focused on the changes perceived to have occurred in the content-area teachers' instructional practices as a result of the training. As discussed in the review of literature, although teachers might have been exposed to new instructional strategies that would be beneficial for the language minority students, the application of these strategies might not be occurring in the classroom. Joyce and Showers (1982) pointed out that, "the development of skill by itself does not ensure transfer; relatively few teachers, having obtained a skill in a new approach, will then transfer that skill into their active repertoire and use the new approach regularly" (p. 5). Transferring the new skill into active use would signify change and change is at times not easily accomplished.

Survey items twelve through forty-three used a five-point Likert attitude scale ranging from Strongly Disagree (S D) to Strongly Agree (S A). "Each response is associated with a point value, and an individual's score is determined by summing the point values for each statement" (Gay, 1981, p. 126). This type of scale was chosen because the researcher wanted to gather data from the respondents which would reflect their perspectives on the issues under study. According to Gay (1981), "attitude scales attempt to determine what an individual believes, perceives, or feels. Attitudes can be measured toward self, others and a variety of other activities, institutions, and situations (p. 126). In addition, Alreck and Settle (1995) state, "a major advantage of this scale is the ability to obtain a 
summated value. ... The total value would be an index of attitudes toward the major issue as a whole" (p. 117). A copy of the final survey instrument is included in Appendix F.

The survey's validity was established through a pilot study. The pilot questionnaire, see Appendix D, was administered to ten content-area teachers who had taken the mandatory training in order to review their comments and responses and make any necessary changes to the instrument. In a cover letter attached to the pilot survey, see Appendix B, the respondents were asked to provide comments and make suggestions regarding the response time, directions, recording procedures, and specific items. According to Sonquist and Dunkelberg (1977) a pilot study or pretest is advisable prior to the actual study due to the following:

A small scale survey gives the researcher an advance opportunity to see failures in questions; to see if questions appear to measure what one wishes to measure; to see if the codes designed as rules for categorizing the data and transferring them from the questionnaire to machine-readable storage medium are properly designed; to find out whether the questionnaire is too long or too short; to ascertain whether or not questions have an optimal ordering; and to locate technical mistakes made in layout or inadequate directions in the instrument (p. 7). 
In other words, a pilot study or pretest will allow the researcher to assess the instrument's validity and reliability as well as make any necessary adjustments. The pilot survey comments recorded on the pilot survey response form, see Appendix C, were examined in order to make any necessary adjustments. For instance, the length of time required to complete the survey ranged from eight to thirty minutes; the majority in the fifteen-minute range. The respondents made no comments regarding the length of time required to complete the survey. The directions were found to be clear and easy to understand. The procedures for recording responses were found to be appropriate. The only change indicated for specific survey items was the designation of the race/ethnicity categories which were changed to reflect the designation used in the Miami-Dade County Public Schools.

The reliability of the survey was established by computing scale reliability. The data from the pilot survey was coded and then analyzed using Cronbach's alpha. This approach to establishing reliability was chosen because according to Rossi, Wright and Anderson (1983):

An approach that most researchers feel is preferable is based on the interitem correlation matrix. Cronbach's alpha is defined as $\alpha=N p /[1+p(N-1)]$, where $N$ is the total number of items and $p$ is the mean correlation among the $\mathrm{N}$ items. If the intercorrelations are high, the items are assumed to be measuring the same thing. Other things equal, high interitem correlation will produce a high alpha (p. 254). 
The results of the Cronbach's Alpha reliability analysis performed on the pretest data indicated an overall reliability of .92 . This is considered high reliability. Further analysis of the reliability results revealed that the overall reliability would increase to .93 when item seventeen was removed. Since removal of item seventeen does not impact upon the instrument's validity, it was deleted for the final version of the survey.

\section{PROCEDURES}

Once the validity and the reliability of the questionnaire were established, an application to conduct research was submitted to the Research Review Committee of the Office of Education Evaluation, Miami-Dade County Public Schools in order: 1) to obtain permission to conduct the survey; 2) to generate a roster of the currently employed content-area teachers in the Miami-Dade County Public Schools who have taken the teacher training course mandated by the Consent Decree; and 3) to attain permission to send the survey to the respondents' school sites through postal mail.

After permission to send the survey was granted, see Appendix A, the means of gathering data was to send a questionnaire to each randomly selected respondent. They were sent a return envelope addressed to the researcher for ease of response. A cover letter explaining the purpose of the study, assuring the respondents of the anonymity of their responses, and thanking them for their participation was included. A copy of the survey cover letter is included in Appendix E. In order to protect anonymity yet maintain a record of who had 
returned the survey, a postcard addressed to the researcher was included with the survey. The postcard contained the respondent's name. The respondents were instructed in the cover letter to drop the postcard in the mail separate from the completed survey. In this manner, a roster could be maintained which allowed the researcher to know who had responded, but did not allow the researcher to match the postcards to the survey. This method facilitated sending a follow-up postcard to those who did not respond to the initial mailing. A reminder notice was mailed a week after the initial surveys. The follow-up postcards were mailed out a month after the initial surveys.

\section{STATISTICAL ANALYSIS}

This study focused on the teachers' perceptions of the effect the training for content-area teachers of LEP students mandated by the Consent Decree has had on these teachers' instructional practices. This broad focus was evaluated by testing nine subsidiary questions. The first three subsidiary questions focused on the teachers' perceptions concerning the need for second language instructional strategies, the mandated teacher training requirement, and the application of second language instructional strategies within the content-area classroom. The next six subsidiary questions focused on the differences found in the teachers' perceptions concerning the aforementioned issues depending on gender, race/ethnicity, age, bilingualism, years of teaching, teaching assignment, content-area, and type or year of training. 
Each response from the survey was assigned a numeric value. The numeric values for the demographic information ranged from one to six depending on the type of demographic information requested. Using the Likert scale, each response to questions twelve through forty-three from the survey was associated with a point value ranging from one to five. The point value of "one" was associated with the response Strongly Disagree, "two" with the response Disagree, "three" with the response Neutral, "four" with the response Agree, and "five" with the response Strongly Agree.

All of the data collected through the responses to the survey were analyzed using both descriptive and inferential statistics. Descriptive statistics included measures of central tendency. Inferential statistics used included Multivariate Factorial Analysis of Variance.

When inferential statistics are used, it is considered appropriate to set the significance level before the analysis procedures are conducted. The significance level refers to the probability that the difference observed could be due to chance. The significance level was set at a value of 0.05 , a value also known as alpha. Consequently, any statistic that had a value that occurred less than five percent of the time was considered significant.

A table was created which separated the data into three columns. The first column included the subsidiary research questions. The second column included the items on the survey which were related to each particular subsidiary research question. The third column included the appropriate test of significance to be 
used in analyzing each particular subsidiary question and the survey items related to it. All of the data analyzed was gathered from the responses to the survey.

\section{SUBSIDIARY QUESTION RELATED ITEM ON SURVEY}

1. What are the content-area teachers' perceptions concerning the LEP students' need of second language instructional strategies within the content-area classroom?

2. What are the content-area teachers' perceptions concerning the teacher-training mandated in the Consent Decree?

3. What changes are perceived to have occurred in the content-area teachers' instructional practices as a result of the training?

4. Is there a significant difference in the contentarea teachers' perceptions of the mandated teacher-training depending on gender, race/ethnicity, age, birthplace, bilingualism?
12-13-14-15-16

$17-18-19-20-21$

22-23-24-25-26

27-28-29-30-31

32

33-34-35-36-37

$38-39-40-41-42$

43

22-25-26-27

30-31-32

analyzed

against

1-2-3-5

\section{APPROPRIATE TEST OF SIGNIFICANCE}

Cross-classification Analysis

Mean

Standard Deviation

Chi-square
Cross-classification Analysis

Mean

Standard Deviation

Chi-square

Cross-classification Analysis

Mean

Standard Deviation

Chi-square
Multivariate Factorial

Analysis of

Variance 
5. Is there a significant

difference in the content-

area teachers' perceptions

of the need for second

language instructional

strategies depending on

their years of teaching,

teaching assignment,

and content-area?

\section{Is there a significant}

difference in the content-

area teachers" perceptions

concerning the application

of second language strategies

depending on their years of

teaching, teaching assignment,

and content-area?

7. Is there a significant

difference in the content-

area teachers' perceptions

of the mandated training

depending on how they

were trained and when they

were trained?

8. Is there a significant

difference in the content-

area teachers' perceptions

of the need for second

language instructional

strategies depending on how

they were trained and when

they were trained?

9. Is there a significant

difference in the content-

area teachers' perceptions

concerning the application of

second language instructional

strategies depending on

how they were trained and

when they were trained?
13-14-15-16

$17-18$

analyzed

against

7-8-9

34-36-38-41

analyzed

against

7-8-9

22-25-26-27

analyzed

against

10-11

13-14-15-16

17-18

analyzed

against

10.11

34-36-38-41

$42-43$

analyzed

against

10-11
Multivariate Factorial

Analysis of

Variance
Multivariate Factorial Analysis of Variance
Multivariate Factorial Analysis of

Variance
Multivariate Factorial Analysis of

Variance
Multivariate Factorial

Analysis of

Variance 


\section{SUMMARY}

The conceptualization, research rationale, definition of the population, definition of the sample, quantitative descriptive design, data collection procedures, and statistical analysis to be used in this study were introduced and discussed in this chapter. 


\section{CHAPTER FOUR}

\section{DATA ANALYSIS}

This chapter will present the findings of the statistical analysis of the data. It will present a discussion based on the analysis of each subsidiary question and the survey items related to these questions. Statistical analyses were performed to determine if a relationship existed between the perceptions of the content-area teachers and the need for second language instructional strategies, the mandated teacher training requirement, and the implementation of second language instructional strategies within the content-area classroom. Statistical analyses were also performed to determine if there were significant differences in these perceptions based on gender, race/ethnicity, age, bilingualism, years of teaching, teaching assignment, content-area, and type or year of training.

The format of this chapter will include a presentation of the demographic characteristics of the respondents; a discussion of the descriptive and inferential statistics used in analyzing the first three subsidiary questions which will include measures of central tendency, variability, and association; a discussion of the inferential statistics used in analyzing the next six subsidiary questions which will include Multivariate Factorial Analysis of Variance; and an overall summary of the results.

Of the 400 questionnaires distributed, there was a total of 274 completed and returned. This constitutes an overall $69 \%$ return rate. In order to ensure the proportional representation of those surveyed to school level, a stratified random sampling technique was used. Out of the 400 questionnaires sent out, 244 , or $61 \%$, were sent to elementary school teachers; 80 , or $20 \%$, were sent to middle 
school teachers; and 76 , or $19 \%$, were sent to high school teachers. Out of the 244 elementary school teachers, 163 responded which constitutes a $67 \%$ response rate. Out of the 80 middle school teachers, 55 responded which constitutes a $69 \%$ response rate. Out of the 76 high school teachers, 53 responded which constitutes a $70 \%$ response rate. Three of the teachers surveyed did not indicate their teaching level. See Table 1.

Table 1

Distribution of Questionnaires Sent and Returned

\begin{tabular}{lccc}
\hline Teaching Level & Sent & Returned & Percent \\
Elementary School & 244 & 163 & $67 \%$ \\
Middle School & 80 & 55 & $69 \%$ \\
Secondary School & 76 & 53 & $70 \%$ \\
Not Provided & N/A & 3 & N/A \\
Total & 400 & 274 & $69 \%$ \\
\hline
\end{tabular}

It should also be noted that out of the 274 survey respondents thirty-four of them did not indicate their specific content-area and thus were eliminated from the following statistical analyses of the three subsidiary questions. The content-area teachers' perceptions were measured by asking them to respond to a series of survey questions using a 5-point Likert scale ranging from a value of " 1 " for Strongly Disagree (S D) to a value of "5" for Strongly Agree (S A). 
Subsidiary Question One: What are the content-area teachers' perceptions concerning the LEP students' need of second language instructional strategies within the content-area classroom?

Table 2 reports the means and the standard deviations of the responses to items 12 through 21 by content area. The means for the responses to items 13 through 20 tend to range between Neutral and Agree for all content-areas. More specifically, the lowest overall mean for the six content-areas was found on item 19 at 3.23; the highest overall mean was found on item 17 at 3.83. The means for the responses to item 12 (The Consent Decree provides LEP students with more educational rights than other students) and the means for the responses to item 21 (The teaching of the LEP student should be done solely by the bilingual department teachers) appear to range between Disagree and Neutral. More specifically, the lowest overall mean for the six content-areas was found on item 21 at 2.28 and the highest overall mean was found on item 12 at 2.85

Tables 3 through 12 show how the content-area teachers responded to the individual survey items using the Likert scale. The tables show both the total number of content-area teachers and those teachers divided by content-area. For clarity of discussion, rather than present the number of responses in each Likert scale category, the five categories will be collapsed into three categories as follows: 1) Strongly Disagree and Disagree, 2) Neutral, and 3) Agree and Strongly Agree. This procedure will be followed throughout the analyses unless it is more appropriate to discuss as distinct responses. 
Table 2

Means and Standard Deviations of Questionnaire Items 12 through 21 by Content-area

\begin{tabular}{|c|c|c|c|c|c|c|c|c|c|c|c|c|}
\hline \multirow{2}{*}{\multicolumn{2}{|c|}{$\begin{array}{l}\text { Con- } \\
\text { tent }\end{array}$}} & Item & Item & Item & Item & Item & Item & Item & Item & Item & Item & \\
\hline & & & & & & 16 & 17 & 18 & 19 & 20 & 21 & \\
\hline \multirow[t]{3}{*}{ Elem. } & M & 2.85 & 3.78 & 3.68 & 3.69 & 3.41 & 3.88 & 3.65 & 3.35 & 3.29 & 2.02 & \\
\hline & n & 142 & 142 & 142 & 142 & 142 & 142 & 142 & 142 & 142 & 142 & \\
\hline & $\mathrm{SD}$ & 1.07 & .88 & .90 & .92 & .96 & .79 & .98 & .88 & 1.11 & .97 & \\
\hline \multirow[t]{3}{*}{ Eng. } & $\underline{\mathbf{M}}$ & 2.70 & 3,48 & 3.59 & 3.89 & 3.44 & 3.89 & 3.74 & 3.07 & 3.44 & 2.22 & \\
\hline & n & 27 & 27 & 27 & 27 & 27 & 27 & 27 & 27 & 27 & 27 & \\
\hline & $\mathrm{SD}$ & 1.10 & 1.05 & 1.01 & .80 & .93 & .89 & 1.02 & .83 & .97 & 1.31 & \\
\hline \multirow[t]{3}{*}{ Math } & M & 3.30 & 3.48 & 3.19 & 3.48 & 3.15 & 3.70 & 3.59 & 2.96 & 3.33 & 3.07 & \\
\hline & $\underline{n}$ & 27 & 27 & 27 & 27 & 27 & 27 & 27 & 27 & 27 & 27 & \\
\hline & $\mathrm{SD}$ & 1.14 & .89 & 1.11 & .85 & .99 & .82 & .93 & .76 & 1.00 & 1.44 & \\
\hline \multirow[t]{3}{*}{ Sci. } & $\underline{M}$ & 3.10 & 3.90 & 3.65 & 3.75 & 3.20 & 3.75 & 3.45 & 3.35 & 3.35 & 2.80 & \\
\hline & $\underline{n}$ & 20 & 20 & 20 & 20 & 20 & 20 & 20 & 20 & 20 & 20 & \\
\hline & SD & 1.12 & .55 & .88 & .91 & 1.24 & 85 & 1.32 & .67 & 1.35 & 1.06 & \\
\hline Soc. & M & 2.16 & 3.47 & 3.32 & 3.37 & 3.21 & 3.68 & 3.42 & 2.74 & 3.21 & 2.58 & \\
\hline \multirow[t]{2}{*}{ Stud. } & $\mathrm{n}$ & 19 & 19 & 19 & 19 & 19 & 19 & 19 & 19 & 19 & 19 & \\
\hline & SD & .96 & 1.39 & 1.29 & 1.38 & 1.40 & .95 & 1.43 & .87 & 1.23 & 1.54 & \\
\hline Comp. & M & 3.00 & 3.60 & 3.40 & 3.60 & 4.00 & 3.80 & 4.20 & 3.60 & 3.40 & 2.20 & \\
\hline \multirow[t]{2}{*}{ Lit. } & $\mathrm{n}$ & 5 & 5 & 5 & 5 & 5 & 5 & 5 & 5 & 5 & 5 & \\
\hline & $\underline{\mathrm{SD}}$ & 1.41 & .89 & .89 & .55 & .71 & 1.30 & .84 & .89 & 1.14 & 1.30 & \\
\hline \multirow[t]{3}{*}{ Total } & $\underline{M}$ & 2.85 & 3.70 & 3.57 & 3.67 & 3.36 & 3.83 & 3.63 & 3.23 & 3.31 & 2.28 & \\
\hline & $\underline{n}$ & 240 & 240 & 240 & 240 & 240 & 240 & 240 & 240 & 240 & 240 & \\
\hline & $\mathrm{SD}$ & 1.10 & .93 & .98 & .94 & 1.02 & .83 & 1.04 & .86 & 1.11 & 1.19 & \\
\hline
\end{tabular}

Table 3 shows the responses to item 12 (The Consent Decree provides Limited English Proficient (LEP) students with more educational rights than other students have). The majority of the responses appear divided relatively evenly among Disagree, Neutral, and Agree for all content-areas except Social Studies . For this group the responses appear divided relatively evenly among Strongly 
Disagree, Disagree, and Neutral. The results of the Chi-square test are not significant at the .05 level, $x^{2}(20, \mathrm{~N}=240)=27.7, \mathrm{p}=.116$. Thus, there is not sufficient evidence to indicate that teachers' perceptions of LEP students as being provided with more educational rights than other students due to the Consent Decree are affected by the content-area in which they teach.

Table 3

Teachers' Perceptions of Questionnaire Item 12 by Content-area

\begin{tabular}{|c|c|c|c|c|c|c|c|c|}
\hline & $\begin{array}{l}\text { Content- } \\
\text { area }\end{array}$ & Elem. & Eng. & Math & Sci, & $\begin{array}{l}\text { Soc, } \\
\text { Stud. }\end{array}$ & $\begin{array}{r}\text { Comp. } \\
\text { Lit. }\end{array}$ & Total \\
\hline \multirow[t]{2}{*}{ S D } & Count & 12 & 3 & 1 & 1 & 6 & & 23 \\
\hline & $\begin{array}{l}\% \text { within } \\
\text { content }\end{array}$ & $8.5 \%$ & $11.1 \%$ & $3.7 \%$ & $5.0 \%$ & $31.6 \%$ & & $9.6 \%$ \\
\hline \multirow[t]{2}{*}{$\mathrm{D}$} & Count & 47 & 11 & 7 & 6 & 5 & 3 & 79 \\
\hline & $\begin{array}{l}\% \text { within } \\
\text { content }\end{array}$ & $33.1 \%$ & $40.7 \%$ & $25.9 \%$ & $30.0 \%$ & $26.3 \%$ & $60.0 \%$ & $32.9 \%$ \\
\hline \multirow[t]{2}{*}{$\mathrm{N}$} & Count & 44 & 5 & 6 & 5 & 7 & & 67 \\
\hline & $\begin{array}{l}\% \text { within } \\
\text { content }\end{array}$ & $31.0 \%$ & $18.5 \%$ & $22.2 \%$ & $25.0 \%$ & $36.8 \%$ & & $27.9 \%$ \\
\hline \multirow[t]{2}{*}{ A } & Count & 29 & 7 & 9 & 6 & 1 & 1 & 53 \\
\hline & $\begin{array}{l}\% \text { within } \\
\text { content }\end{array}$ & $20.4 \%$ & $25.9 \%$ & $33.3 \%$ & $30.0 \%$ & $5.3 \%$ & $20.0 \%$ & $22.1 \%$ \\
\hline \multirow[t]{2}{*}{ SA } & Count & 10 & 1 & 4 & 2 & & 1 & 18 \\
\hline & $\begin{array}{l}\% \text { within } \\
\text { content }\end{array}$ & $7.0 \%$ & $3.7 \%$ & $14.8 \%$ & $10.0 \%$ & & $20.0 \%$ & $7.5 \%$ \\
\hline \multirow[t]{2}{*}{ Total } & Count & 142 & 27 & 27 & 20 & 19 & 5 & 240 \\
\hline & $\begin{array}{l}\% \text { within } \\
\text { content }\end{array}$ & $100.0 \%$ & $100.0 \%$ & $100.0 \%$ & $100.0 \%$ & $100.0 \%$ & $100.0 \%$ & $100.0 \%$ \\
\hline
\end{tabular}


Table 4 shows the responses to item 13 (Second language instructional strategies geared to the LEP students facilitate their ability to comprehend the content-area lesson better). The majority of the responses appear clustered under the category of Agree and Strongly Agree for all content-areas with the exception of Mathematics. The Mathematics teachers tended to rate this item as either Neutral or Agree. As a result the Chi-square test was found to be significant, $x^{2}$ $(20, \underline{N}=240)=33.26, p=.032$. Thus, there appears to be a relationship between the content-area of the teachers and their perceptions concerning whether second language strategies geared to the LEP students facilitate their ability to comprehend the content-area lesson better.

Table 5 shows the responses to item 14 (Second language instructional strategies geared towards the LEP students facilitate their social development). The majority of the responses appear clustered under the category of Agree and Strongly Agree for all content-areas. The majority of the remaining responses tend to be in the Neutral category for all content-areas except Mathematics, where there is a greater emphasis on Disagree. The results of the Chi-square test are not significant at the .05 level, $x^{2}(20, \underline{N}=240)=30.60, \mathrm{p}=.061$. Thus, there is not enough evidence to indicate that teachers' perceptions of second language instructional strategies as facilitating the LEP students social development are dependent upon the content-area in which they teach. 
Table 4

Teachers' Perceptions of Questionnaire Item 13 by Content-area

\begin{tabular}{|c|c|c|c|c|c|c|c|c|}
\hline & $\begin{array}{l}\text { Content- } \\
\text { area }\end{array}$ & Elem. & Eng. & Math & Sci. & $\begin{array}{l}\text { Soc. } \\
\text { Stud. }\end{array}$ & $\begin{array}{r}\text { Comp. } \\
\text { Lit. }\end{array}$ & Total \\
\hline \multirow{2}{*}{$\begin{array}{l}\text { Strongly } \\
\text { Disagree }\end{array}$} & Count & 1 & 1 & 1 & & 3 & & 6 \\
\hline & $\begin{array}{l}\% \text { within } \\
\text { content }\end{array}$ & $.7 \%$ & $3.7 \%$ & $3.7 \%$ & & $15.8 \%$ & & $2.5 \%$ \\
\hline \multirow[t]{2}{*}{ Disagree } & Count & 13 & 5 & 2 & & 2 & 1 & 23 \\
\hline & $\begin{array}{l}\% \text { within } \\
\text { content }\end{array}$ & $9.2 \%$ & $18.5 \%$ & $7.4 \%$ & & $10.5 \%$ & $20.0 \%$ & $9.6 \%$ \\
\hline \multirow[t]{2}{*}{ Neutral } & Count & 29 & 4 & 9 & 4 & 1 & & 47 \\
\hline & $\begin{array}{l}\% \text { within } \\
\text { content }\end{array}$ & $20.4 \%$ & $14.8 \%$ & $33.3 \%$ & $20.0 \%$ & $5.3 \%$ & & $19.6 \%$ \\
\hline \multirow[t]{2}{*}{ Agree } & Count & 72 & 14 & 13 & 14 & 9 & 4 & 126 \\
\hline & $\begin{array}{l}\% \text { within } \\
\text { content }\end{array}$ & $50.7 \%$ & $51.9 \%$ & $48.1 \%$ & $70.0 \%$ & $47.4 \%$ & $80.0 \%$ & $52.5 \%$ \\
\hline \multirow{2}{*}{$\begin{array}{l}\text { Strongly } \\
\text { Agree }\end{array}$} & Count & 27 & 3 & 2 & 2 & 4 & & 38 \\
\hline & $\begin{array}{l}\% \text { within } \\
\text { content }\end{array}$ & $19.0 \%$ & $11.1 \%$ & $7.4 \%$ & $10.0 \%$ & $21.1 \%$ & & $15.8 \%$ \\
\hline \multirow[t]{2}{*}{ Total } & Count & 142 & 27 & 27 & 20 & 19 & 5 & 240 \\
\hline & $\begin{array}{l}\% \text { within } \\
\text { content }\end{array}$ & $100.0 \%$ & $100.0 \%$ & $100.0 \%$ & $100.0 \%$ & $100.0 \%$ & $100.0 \%$ & $100.0 \%$ \\
\hline
\end{tabular}


Table 5

Teachers' Perceptions of Questionnaire Item 14 by Content-area

\begin{tabular}{|c|c|c|c|c|c|c|c|c|}
\hline & $\begin{array}{l}\text { Content- } \\
\text { area }\end{array}$ & Elem. & Eng. & Math & Sci. & $\begin{array}{l}\text { Soc. } \\
\text { Stud. }\end{array}$ & $\begin{array}{r}\text { Comp. } \\
\text { Lit }\end{array}$ & Total \\
\hline \multirow[t]{2}{*}{ SD } & Count & 1 & 1 & 2 & & 3 & & 6 \\
\hline & $\begin{array}{l}\% \text { within } \\
\text { content }\end{array}$ & $.7 \%$ & $3.7 \%$ & $7.4 \%$ & & $15.8 \%$ & & $2.5 \%$ \\
\hline \multirow[t]{2}{*}{$\mathrm{D}$} & Count & 17 & 5 & 7 & 2 & 2 & 1 & 34 \\
\hline & $\begin{array}{l}\% \text { within } \\
\text { content }\end{array}$ & $12.0 \%$ & $18.5 \%$ & $25.9 \%$ & $10.0 \%$ & $10.5 \%$ & $20.0 \%$ & $14.2 \%$ \\
\hline \multirow[t]{2}{*}{$\mathrm{N}$} & Count & 31 & 6 & 3 & 6 & 2 & 1 & 49 \\
\hline & $\begin{array}{l}\% \text { within } \\
\text { content }\end{array}$ & $21.8 \%$ & $22.2 \%$ & $11.1 \%$ & $30.0 \%$ & $10.5 \%$ & $20.0 \%$ & $20.4 \%$ \\
\hline \multirow[t]{2}{*}{ A } & Count & 71 & 11 & 14 & 9 & 10 & 3 & 118 \\
\hline & $\begin{array}{l}\% \text { within } \\
\text { content }\end{array}$ & $50.0 \%$ & $40.7 \%$ & $51.9 \%$ & $45.0 \%$ & $52.6 \%$ & $60.0 \%$ & $49.2 \%$ \\
\hline \multirow[t]{2}{*}{ SA } & Count & 22. & 5 & 1 & 3 & 2 & & 33 \\
\hline & $\begin{array}{l}\% \text { within } \\
\text { content }\end{array}$ & $15.5 \%$ & $18.5 \%$ & $3.7 \%$ & $15.0 \%$ & $10.5 \%$ & & $13.8 \%$ \\
\hline \multirow[t]{2}{*}{ Total } & Count & 142 & 27 & 27 & 20 & 19 & 5 & 240 \\
\hline & $\begin{array}{l}\% \text { within } \\
\text { content }\end{array}$ & $100.0 \%$ & $100.0 \%$ & $100.0 \%$ & $100.0 \%$ & $100.0 \%$ & $100.0 \%$ & $100.0 \%$ \\
\hline
\end{tabular}


Table 6 shows the responses to item 15 (Second language instructional strategies geared towards the LEP students allow them to experience greater academic success in the content-areas). The majority of the responses appear clustered under the category of Agree and Strongly Agree for all content-areas. Mathematics and Computer Literacy teachers, on the other hand, also tended to respond in the Neutral category. The significance level of the Chi-square test is .044 indicating that the results of the Chi-square test are significant at the .05 level, $x^{2}(20, \underline{N}=240)=31.93, p=.044$. Thus, there appears to be a relationship between the content-area of the teachers and their perceptions concerning whether second language strategies geared towards the LEP students allow them to experience success in the content-area classroom.

Table 7 shows the responses to item 16 ( Second language instructional strategies learned through the META teacher training are helpful to me in meeting the LEP students' language needs). The majority of the responses appear clustered under the category of Agree and Strongly Agree for all content-areas. There follows a clustering of the majority of the remaining responses under Neutral for all content-areas except Social Studies, where the emphasis is on Strongly Disagree. The results of the Chi-square test are not significant at the .05 level, $x^{2}(20, \mathrm{~N}=240)=22.85, \mathrm{df}=20, \mathrm{p}=.296$. Thus, there is not sufficient evidence to indicate that teachers' perceptions concerning whether the second language instructional strategies learned through the META teacher training are helpful to them in meeting the LEP students' language needs are affected by the content- area in which they teach. 
Table 6

Teachers' Perceptions of Questionnaire Item 15 by Content-area

\begin{tabular}{|c|c|c|c|c|c|c|c|c|}
\hline & $\begin{array}{l}\text { Content- } \\
\text { area }\end{array}$ & Elem. & Eng. & Math & Sc: & $\begin{array}{l}\text { Soc. } \\
\text { Stud. }\end{array}$ & $\begin{array}{c}\text { Comp. } \\
\text { Lit. }\end{array}$ & Tota! \\
\hline \multirow[t]{2}{*}{$\mathrm{SD}$} & Count & 1 & & 1 & 1 & 3 & & 6 \\
\hline & $\begin{array}{l}\% \text { within } \\
\text { content }\end{array}$ & $.7 \%$ & & $3.7 \%$ & $5.0 \%$ & $15.8 \%$ & & $2.5 \%$ \\
\hline \multirow[t]{2}{*}{ D } & Count & 21 & 2 & 2 & 1 & 2 & & 28 \\
\hline & $\begin{array}{l}\% \text { within } \\
\text { content }\end{array}$ & $14.8 \%$ & $7.4 \%$ & $7.4 \%$ & $5.0 \%$ & $10.5 \%$ & & $11.7 \%$ \\
\hline \multirow[t]{2}{*}{$\mathrm{N}$} & Count & 20 & 4 & 8 & 2 & 3 & 2 & 39 \\
\hline & $\begin{array}{l}\% \text { within } \\
\text { content }\end{array}$ & $14.1 \%$ & $14.8 \%$ & $29.6 \%$ & $10.0 \%$ & $15.8 \%$ & $40.0 \%$ & $16.3 \%$ \\
\hline \multirow[t]{2}{*}{ A } & Count & 79 & 16 & 15 & 14 & 7 & 3 & 134 \\
\hline & $\begin{array}{l}\% \text { within } \\
\text { content }\end{array}$ & $55.6 \%$ & $59.3 \%$ & $55.6 \%$ & $70.0 \%$ & $36.8 \%$ & $60.0 \%$ & $55.8 \%$ \\
\hline \multirow[t]{2}{*}{ S A } & Count & 21 & 5 & 1 & 2 & 4 & & 33 \\
\hline & $\begin{array}{l}\% \text { within } \\
\text { content }\end{array}$ & $14.8 \%$ & $18.5 \%$ & $3.7 \%$ & $10.0 \%$ & $21.1 \%$ & & $13.8 \%$ \\
\hline \multirow[t]{2}{*}{ Total } & Count & 142 & 27 & 27 & 20 & 19 & 5 & 240 \\
\hline & $\begin{array}{l}\% \text { within } \\
\text { content }\end{array}$ & $100.0 \%$ & $100.0 \%$ & $100.0 \%$ & $100.0 \%$ & $100.0 \%$ & $100.0 \%$ & $100.0 \%$ \\
\hline
\end{tabular}


Table 7

Teachers' Perceptions of Questionnaire Item 16 by Content-area

\begin{tabular}{|c|c|c|c|c|c|c|c|c|c|}
\hline \multirow{3}{*}{\multicolumn{2}{|c|}{ Item 16}} & $\begin{array}{l}\text { Content- } \\
\text { area }\end{array}$ & Elem. & Eng. & Math & Sci. & $\begin{array}{l}\text { Soc. } \\
\text { Stud. }\end{array}$ & $\begin{array}{r}\text { Comp. } \\
\text { Lit. }\end{array}$ & Total \\
\hline & & Count & 4 & 1 & 2 & 3 & 4 & & 14 \\
\hline & & $\begin{array}{l}\% \text { within } \\
\text { content }\end{array}$ & $2.8 \%$ & $3.7 \%$ & $7.4 \%$ & $15.0 \%$ & $21.1 \%$ & & $5.8 \%$ \\
\hline \multirow{2}{*}{\multicolumn{2}{|c|}{ D }} & Count & 23 & 3 & 5 & 2 & 2 & & 35 \\
\hline & & $\begin{array}{l}\% \text { within } \\
\text { content }\end{array}$ & $16.2 \%$ & $11.1 \%$ & $18.5 \%$ & $10.0 \%$ & $10.5 \%$ & & $14.6 \%$ \\
\hline \multirow{2}{*}{\multicolumn{2}{|c|}{$\mathbf{N}$}} & Count & 39 & 8 & 7 & 5 & 1 & 1 & 61 \\
\hline & & $\begin{array}{l}\% \text { within } \\
\text { content }\end{array}$ & $27.5 \%$ & $29.6 \%$ & $25.9 \%$ & $25.0 \%$ & 5.35 & $20.0 \%$ & $25.4 \%$ \\
\hline \multirow{2}{*}{\multicolumn{2}{|c|}{$\mathbf{A}$}} & Count & 63 & 13 & 13 & 8 & 10 & 3 & 110 \\
\hline & & $\begin{array}{l}\% \text { within } \\
\text { content }\end{array}$ & $44.4 \%$ & $48.1 \%$ & $48.1 \%$ & $40.0 \%$ & $52.6 \%$ & $60.0 \%$ & $45.8 \%$ \\
\hline \multirow{2}{*}{\multicolumn{2}{|c|}{$\mathbf{S A}$}} & Count & 13 & 2 & & 2 & 2 & 1 & 20 \\
\hline & & $\begin{array}{l}\% \text { within } \\
\text { content }\end{array}$ & $9.2 \%$ & $7.4 \%$ & & $10.0 \%$ & $10.5 \%$ & $20.0 \%$ & $8.3 \%$ \\
\hline \multirow{2}{*}{\multicolumn{2}{|c|}{ Total }} & Count & 142 & 27 & 27 & 20 & 19 & 5 & 240 \\
\hline & & $\begin{array}{l}\% \text { within } \\
\text { content }\end{array}$ & $100.0 \%$ & $100.0 \%$ & $100.0 \%$ & $100.0 \%$ & $100.0 \%$ & $100.0 \%$ & $100.0 \%$ \\
\hline
\end{tabular}


Table 8 shows the responses to item 17 (LEP students require second language instructional strategies geared to their individual level of English proficiency). The majority of the responses appear clustered under the category of Agree and Strongly Agree for all content-areas. The majority of the remaining responses tend to be in the Neutral category. The results of the Chi-square test are not significant at the .05 level, $x^{2}(20, \mathrm{~N}=240)=17.61, \mathrm{p}=.613$. Thus, there is not enough evidence to indicate that teachers' perceptions of LEP students as requiring second language instructional strategies geared to their individual level of English proficiency are dependent upon the content-area in which they teach.

Table 9 shows the responses to item 18 (Second language instructional strategies geared towards LEP students are necessary in order to provide them with equal educational opportunity). The majority of the responses appear clustered under the category of Agree and Strongly Agree for all content-areas. The majority of the remaining responses tend to be under either Disagree or Strongly Disagree. The results of the Chi-square test are not significant at the .05 level, $x^{2}(20, \underline{\mathrm{N}}=240)=24.53, \mathrm{p}=.220$. Thus, there is not sufficient evidence to indicate that teachers' perceptions concerning whether second language instructional strategies are necessary in order to provide LEP students with equal educational opportunity are affected by the content-area in which they teach. 
Table 8

Teachers' Perceptions of Questionnaire Item 17 by Content-area

\begin{tabular}{|c|c|c|c|c|c|c|c|c|}
\hline & $\begin{array}{l}\text { Content- } \\
\text { area }\end{array}$ & Elem. & Eng. & Math & Sci. & $\begin{array}{l}\text { Soc. } \\
\text { Stud. }\end{array}$ & $\begin{array}{r}\text { Comp. } \\
\text { Lit }\end{array}$ & Total \\
\hline \multirow[t]{2}{*}{$S D$} & Count & & & 1 & & 1 & & 2 \\
\hline & $\begin{array}{l}\text { \% within } \\
\text { content }\end{array}$ & & & $3.7 \%$ & & $5.3 \%$ & & $.8 \%$ \\
\hline \multirow[t]{2}{*}{$\mathrm{D}$} & Count & 11 & 3 & 1 & 2 & 1 & 1 & 19 \\
\hline & $\begin{array}{l}\% \text { within } \\
\text { content }\end{array}$ & $7.7 \%$ & $11.1 \%$ & $3.7 \%$ & $10.0 \%$ & $5.3 \%$ & $20.0 \%$ & $7.9 \%$ \\
\hline \multirow[t]{2}{*}{$\mathrm{N}$} & Count & 21 & 3 & 5 & 4 & 3 & 1 & 37 \\
\hline & $\begin{array}{l}\% \text { within } \\
\text { content }\end{array}$ & $14.8 \%$ & $11.1 \%$ & $18.5 \%$ & $20.0 \%$ & $15.8 \%$ & $20.0 \%$ & $15.4 \%$ \\
\hline \multirow[t]{2}{*}{ A } & Count & 84 & 15 & 18 & 11 & 12 & 1 & 141 \\
\hline & $\begin{array}{l}\% \text { within } \\
\text { content }\end{array}$ & $59.2 \%$ & $55.6 \%$ & $66.7 \%$ & $55.0 \%$ & $63.2 \%$ & $20.0 \%$ & $58.8 \%$ \\
\hline \multirow[t]{2}{*}{ S A } & Count & 26 & 6 & 2 & 3 & 2 & 2 & 41 \\
\hline & $\begin{array}{l}\% \text { within } \\
\text { content }\end{array}$ & $18.3 \%$ & $22.2 \%$ & $7.4 \%$ & $15.0 \%$ & $10.5 \%$ & $40.0 \%$ & $17.1 \%$ \\
\hline \multirow[t]{2}{*}{ Total } & Count & 142 & 27 & 27 & 20 & 19 & 5 & 240 \\
\hline & $\begin{array}{l}\% \text { within } \\
\text { content }\end{array}$ & $100.0 \%$ & $100.0 \%$ & $100.0 \%$ & $100.0 \%$ & $100.0 \%$ & $100.0 \%$ & $100.0 \%$ \\
\hline
\end{tabular}


Table 9

Teachers' Perceptions of Questionnaire Item 18 by Content-area

\begin{tabular}{|c|c|c|c|c|c|c|c|c|}
\hline & $\begin{array}{l}\text { Content- } \\
\text { area }\end{array}$ & Elem. & Eng. & Math & Sci. & $\begin{array}{l}\text { Soc. } \\
\text { Stud. }\end{array}$ & $\begin{array}{r}\text { Comp. } \\
\text { Lit }\end{array}$ & Total \\
\hline \multirow[t]{2}{*}{ SD } & Count & 2 & 1 & 1 & 3 & 3 & & 10 \\
\hline & $\begin{array}{l}\% \text { within } \\
\text { content }\end{array}$ & $1.4 \%$ & 3.75 & $3.7 \%$ & $15.0 \%$ & $15.8 \%$ & & $4.2 \%$ \\
\hline \multirow[t]{2}{*}{$\mathrm{D}$} & Count & 23 & 3 & 3 & 2 & 3 & & 34 \\
\hline & $\begin{array}{l}\% \text { within } \\
\text { content }\end{array}$ & $16.2 \%$ & $11.1 \%$ & $11.1 \%$ & $10.0 \%$ & $15.8 \%$ & & $14.2 \%$ \\
\hline \multirow[t]{2}{*}{$\mathrm{N}$} & Count & 19 & 3 & 4 & 1 & & 1 & 28 \\
\hline & $\begin{array}{l}\% \text { within } \\
\text { content }\end{array}$ & $13.4 \%$ & $11.1 \%$ & $14.8 \%$ & $5.0 \%$ & & $20.0 \%$ & $11.7 \%$ \\
\hline \multirow[t]{2}{*}{ A } & Count & 76 & 15 & 17 & 11 & 9 & 2 & 130 \\
\hline & $\begin{array}{l}\% \text { within } \\
\text { content }\end{array}$ & $53.5 \%$ & $55.6 \%$ & $63.0 \%$ & $55.0 \%$ & $47.4 \%$ & $40.0 \%$ & $54.2 \%$ \\
\hline \multirow[t]{2}{*}{ S A } & Count & 22 & 5 & 2 & 3 & 4 & 2 & 38 \\
\hline & $\begin{array}{l}\% \text { within } \\
\text { content }\end{array}$ & $15.5 \%$ & $18.5 \%$ & $7.4 \%$ & $15.0 \%$ & $21.1 \%$ & $40.0 \%$ & $15.8 \%$ \\
\hline \multirow[t]{2}{*}{ Total } & Count & 142 & 27 & 27 & 20 & 19 & 5 & 240 \\
\hline & $\begin{array}{l}\% \text { within } \\
\text { content }\end{array}$ & $100.0 \%$ & $100.0 \%$ & $100.0 \%$ & $100.0 \%$ & $100.0 \%$ & $100.0 \%$ & $100.0 \%$ \\
\hline
\end{tabular}


Table 10 shows the responses to item 19 (The Consent Decree is the first piece of legislation to impact directly on the educational opportunities offered to LEP students). The majority of the responses appear clustered under the category of Neutral for all content-areas. There follows a clustering of the majority of the remaining responses under Agree for all content-areas. The results of the Chi-square test are not significant at the .05 level, $x^{2}(20, \underline{N}=240)=28.04$, $p=.108$. Thus, there is not enough evidence to indicate that teachers' perceptions of the Consent Decree as the first piece of legislation to impact directly on the educational opportunities offered to LEP students are dependent upon the content-area in which they teach.

Table 11 shows the responses to item 20 (The META teacher training made me aware of the instructional needs of the LEP student). The majority of the responses appear clustered under the category of Agree and Strongly Agree for all content-areas. The majority of the remaining responses appear clustered under either Disagree or Strongly Disagree for all content-areas except English, where there is a greater emphasis on the category of Neutral. The results of the Chi-square are not significant at the .05 level, $x^{2}(20, \underline{\mathrm{N}}=240)=18.56, \mathrm{p}=.551$. Thus, there is not sufficient evidence to indicate that teachers' perceptions that the META teacher training made them aware of the instructional needs of the LEP student are affected by the content-area in which they teach. 
Table 10

Teachers' Perceptions of Questionnaire Item 19 by Content-area

\begin{tabular}{|c|c|c|c|c|c|c|c|c|}
\hline & $\begin{array}{l}\text { Content- } \\
\text { area }\end{array}$ & Elem. & Eng. & Math & Sci & $\begin{array}{l}\text { Soc. } \\
\text { Stud. }\end{array}$ & $\begin{array}{c}\text { Comp. } \\
\text { Lit. }\end{array}$ & Total \\
\hline \multirow[t]{2}{*}{ SD } & Count & 2 & 1 & 2 & & 2 & & 7 \\
\hline & $\begin{array}{l}\% \text { within } \\
\text { content }\end{array}$ & $1.4 \%$ & $3.7 \%$ & $7.4 \%$ & & $10.5 \%$ & & $2.9 \%$ \\
\hline \multirow[t]{2}{*}{ D } & Count & 20 & 5 & 2 & 2 & 4 & & 33 \\
\hline & $\begin{array}{l}\% \text { within } \\
\text { content }\end{array}$ & $14.1 \%$ & $18.5 \%$ & $7.4 \%$ & $10.0 \%$ & $21.1 \%$ & & $13.8 \%$ \\
\hline \multirow[t]{2}{*}{$\mathbf{N}$} & Count & 59 & 12 & 18 & 9 & 10 & 3 & 111 \\
\hline & $\begin{array}{l}\% \text { within } \\
\text { content }\end{array}$ & $41.5 \%$ & $44.4 \%$ & $66.7 \%$ & $45.0 \%$ & $52.6 \%$ & $60.0 \%$ & $46.3 \%$ \\
\hline \multirow[t]{2}{*}{ A } & Count & 49 & 9 & 5 & 9 & 3 & 1 & 76 \\
\hline & $\begin{array}{l}\% \text { within } \\
\text { content }\end{array}$ & $34.5 \%$ & $33.3 \%$ & $18.5 \%$ & $45.0 \%$ & $15.8 \%$ & $20.0 \%$ & $31.7 \%$ \\
\hline \multirow[t]{2}{*}{ S A } & Count & 12 & & & & & 1 & 13 \\
\hline & $\begin{array}{l}\% \text { within } \\
\text { content }\end{array}$ & $8.5 \%$ & & & & & $20.0 \%$ & $5.4 \%$ \\
\hline \multirow[t]{2}{*}{ Total } & Count & 142 & 27 & 27 & 20 & 19 & 5 & 240 \\
\hline & $\begin{array}{l}\% \text { within } \\
\text { content }\end{array}$ & $100.0 \%$ & $100.0 \%$ & $100.0 \%$ & $100.0 \%$ & $100.0 \%$ & $100.0 \%$ & $100.0 \%$ \\
\hline
\end{tabular}


Table 11

Teachers' Perceptions of Questionnaire Item 20 by Content-area

\begin{tabular}{|c|c|c|c|c|c|c|c|c|}
\hline & $\begin{array}{l}\text { Content- } \\
\text { area }\end{array}$ & Elem. & Eng. & Math & Sci. & Soc $_{\text {P }}$ & $\begin{array}{r}\text { Comp. } \\
\text { Lit. }\end{array}$ & Total \\
\hline \multirow[t]{2}{*}{ SD } & Count & 7 & 1 & 1 & 3 & 3 & & 15 \\
\hline & $\begin{array}{l}\% \text { within } \\
\text { content }\end{array}$ & $4.9 \%$ & $3.7 \%$ & $3.7 \%$ & $15.0 \%$ & $15.8 \%$ & & $6.3 \%$ \\
\hline \multirow[t]{2}{*}{$\mathrm{D}$} & Count & 36 & 4 & 6 & 3 & 2 & 1 & 52 \\
\hline & $\begin{array}{l}\% \text { within } \\
\text { content }\end{array}$ & $25.4 \%$ & $14.8 \%$ & $22.2 \%$ & $15.0 \%$ & $10.5 \%$ & $20.0 \%$ & $21.7 \%$ \\
\hline \multirow[t]{2}{*}{$\mathrm{N}$} & Count & 24 & 6 & 4 & 1 & 3 & 2 & 40 \\
\hline & $\begin{array}{l}\% \text { within } \\
\text { content }\end{array}$ & $16.9 \%$ & $22.2 \%$ & $14.8 \%$ & $5.0 \%$ & $15.8 \%$ & $40.0 \%$ & $16.7 \%$ \\
\hline \multirow[t]{2}{*}{ A } & Count & 59 & 14 & 15 & 10 & 10 & 1 & 109 \\
\hline & $\begin{array}{l}\% \text { within } \\
\text { content }\end{array}$ & $41.5 \%$ & $51.9 \%$ & $55.6 \%$ & $50.0 \%$ & $52.6 \%$ & $20.0 \%$ & $45.4 \%$ \\
\hline \multirow[t]{2}{*}{ S A } & Count & 16 & 2 & 1 & 3 & 1 & 1 & 24 \\
\hline & $\begin{array}{l}\% \text { within } \\
\text { content }\end{array}$ & $11.3 \%$ & $7.4 \%$ & $3.7 \%$ & $15.0 \%$ & $5.3 \%$ & $20.0 \%$ & $10.0 \%$ \\
\hline \multirow[t]{2}{*}{ Total } & Count & 142 & 27 & 27 & 20 & 19 & 5 & 240 \\
\hline & $\begin{array}{l}\% \text { within } \\
\text { content }\end{array}$ & $100.0 \%$ & $100.0 \%$ & $100.0 \%$ & $100.0 \%$ & $100.0 \%$ & $100.0 \%$ & $100.0 \%$ \\
\hline
\end{tabular}

Table 12 shows the responses for item 21 (Teaching the LEP student should be the responsibility only of the teachers in the Bilingual Program). The majority of the responses appear under the category of Disagree and Strongly Disagree for all content-areas. The majority of the remaining responses tend to appear under the category of Agree and Strongly Agree. The significance level of 
the Chi-square test is .000 indicating that the results of the Chi-square test performed on the data are significant at the .05 level, $x^{2}(20, \underline{N}=240)=48.90$, $p<.0005$. Thus, there appears to be a relationship between the content-area of the teachers and their perceptions concerning whether teaching the LEP student should be the responsibility only of the teachers in the Bilingual Program.

Table 12

Teachers' Perceptions of Questionnaire Item 21 by Content-area

\begin{tabular}{|c|c|c|c|c|c|c|c|c|}
\hline & $\begin{array}{l}\text { Content- } \\
\text { area }\end{array}$ & Elem. & Eng. & Math & Sci. & $\begin{array}{l}\text { Soc. } \\
\text { Stud. }\end{array}$ & $\begin{array}{r}\text { Comp. } \\
\text { Lit. }\end{array}$ & Total \\
\hline \multirow[t]{2}{*}{$S D$} & Count & 41 & 10 & 2 & 1 & 5 & 2 & 61 \\
\hline & $\begin{array}{l}\% \text { within } \\
\text { content }\end{array}$ & $28.9 \%$ & $37.0 \%$ & $7.4 \%$ & $5.0 \%$ & $26.3 \%$ & $40.0 \%$ & $25.4 \%$ \\
\hline \multirow[t]{2}{*}{$\mathrm{D}$} & Count & 76 & 9 & 13 & 9 & 8 & 1 & 116 \\
\hline & $\begin{array}{l}\% \text { within } \\
\text { content }\end{array}$ & $53.5 \%$ & $33.3 \%$ & $48.1 \%$ & $45.0 \%$ & $42.1 \%$ & $20.0 \%$ & $48.3 \%$ \\
\hline \multirow[t]{2}{*}{$\mathrm{N}$} & Count & 11 & 2 & & 4 & & 1 & 18 \\
\hline & $\begin{array}{l}\% \text { within } \\
\text { content }\end{array}$ & $7.7 \%$ & $7.4 \%$ & & $20.0 \%$ & & $20.0 \%$ & $7.5 \%$ \\
\hline \multirow[t]{2}{*}{ A } & Count & 9 & 4 & 5 & 5 & 2. & 1 & 26 \\
\hline & $\begin{array}{l}\text { \% within } \\
\text { content }\end{array}$ & $6.3 \%$ & $14.8 \%$ & $18.5 \%$ & $25.0 \%$ & $10.5 \%$ & $20.0 \%$ & $10.8 \%$ \\
\hline \multirow[t]{2}{*}{ S A } & Count & 5 & 2 & 7 & 1 & 4. & & 19 \\
\hline & $\begin{array}{l}\% \text { within } \\
\text { content }\end{array}$ & $3.5 \%$ & $7.4 \%$ & $25.9 \%$ & $5.0 \%$ & $21.1 \%$ & & $7.9 \%$ \\
\hline \multirow[t]{2}{*}{ Total } & Count & 142 & 27 & 27 & 20 & 19 & 5 & 240 \\
\hline & $\begin{array}{l}\% \text { within } \\
\text { content }\end{array}$ & $100.0 \%$ & $100.0 \%$ & $100.0 \%$ & $100.0 \%$ & $100.0 \%$ & $100.0 \%$ & $100.0 \%$ \\
\hline
\end{tabular}


Subsidiary Question Two: What are the content-area teachers' perceptions concerning the teacher training mandated in the Consent Decree?

Table 13 reports the means and the standard deviations of the responses to items 22 through 32 by content area. All of the means except for item 28 tend to range between Neutral and Agree for all content-areas. More specifically, the lowest overall mean for the six content-areas was found on item 24 at 3.02 and the highest overall mean was found on item 23 at 3.46. The means for the responses to item 28 (The teacher training mandated by the Consent Decree took the teachers' perspectives into consideration in its development) tend to range closer to Neutral than to Agree. More specifically, the lowest individual mean was for Mathematics at 2.56 and the highest individual mean was for Social Studies at 3.11. The overall mean for the six content-areas on this item was 2.85 .

Tables 14 through 24 show how the content-area teachers responded to the individual survey items using the Likert scale. The tables show both the total number of content-area teachers and those teachers divided by content-area. For clarity of discussion, rather than present the number of responses in each Likert scale category, the five categories will be collapsed into three categories as follows: 1) Strongly Disagree and Disagree, 2) Neutral, and 3) Agree and Strongly Agree. This procedure will be followed throughout unless it is more appropriate to discuss as distinct responses. 
Table 13

Means and Standard Deviations of Questionnaire Items 22 through 32 by Content-area

\begin{tabular}{|c|c|c|c|c|c|c|c|c|c|c|c|c|}
\hline $\begin{array}{l}\text { Con- } \\
\text { tent }\end{array}$ & & $\begin{array}{r}\text { Item } \\
22\end{array}$ & $\begin{array}{r}\text { Item } \\
23\end{array}$ & $\begin{array}{r}\text { Item } \\
24\end{array}$ & $\frac{\text { Item }}{25}$ & $\frac{\text { Item }}{26}$ & $\begin{array}{r}\text { Item } \\
27\end{array}$ & $\begin{array}{r}\text { Item } \\
28\end{array}$ & $\begin{array}{r}\text { Item } \\
29\end{array}$ & $\frac{\text { Item }}{30}$ & $\begin{array}{r}\text { Item } \\
31\end{array}$ & $\begin{array}{r}\text { Item } \\
32\end{array}$ \\
\hline Elem. & $\begin{array}{r}\mathrm{M} \\
\mathbf{n} \\
\mathrm{SD}\end{array}$ & $\begin{array}{r}3.19 \\
142 \\
1.10\end{array}$ & $\begin{array}{r}3.37 \\
142 \\
1.00\end{array}$ & $\begin{array}{r}2.86 \\
142 \\
1.09\end{array}$ & $\begin{array}{r}3.29 \\
142 \\
1.28\end{array}$ & $\begin{array}{r}3.40 \\
142 \\
1.05\end{array}$ & $\begin{array}{r}3.31 \\
142 \\
1.00\end{array}$ & $\begin{array}{r}2.82 \\
142 \\
1.00\end{array}$ & $\begin{array}{r}3.51 \\
142 \\
.92\end{array}$ & $\begin{array}{r}3.05 \\
142 \\
1.07\end{array}$ & $\begin{array}{r}3.06 \\
142 \\
.93\end{array}$ & $\begin{array}{r}3.26 \\
142 \\
1.06\end{array}$ \\
\hline Eng. & $\begin{array}{c}\mathrm{M} \\
\mathrm{n} \\
\mathrm{SD}\end{array}$ & $\begin{array}{r}3.30 \\
27 \\
.99\end{array}$ & $\begin{array}{r}3.85 \\
27 \\
.60\end{array}$ & $\begin{array}{r}3.26 \\
27 \\
1.13\end{array}$ & $\begin{array}{r}2.70 \\
27 \\
1.17\end{array}$ & $\begin{array}{r}3.48 \\
27 \\
94\end{array}$ & $\begin{array}{r}3.56 \\
27 \\
.93\end{array}$ & $\begin{array}{r}3.04 \\
27 \\
.85\end{array}$ & $\begin{array}{r}3.26 \\
27 \\
1.06\end{array}$ & $\begin{array}{r}3.30 \\
27 \\
1.07\end{array}$ & $\begin{array}{r}3.00 \\
27 \\
.73\end{array}$ & $\begin{array}{r}3.33 \\
27 \\
.96\end{array}$ \\
\hline Math & $\begin{array}{c}\mathrm{M} \\
\underline{\mathrm{n}} \\
\mathrm{SD}\end{array}$ & $\begin{array}{r}2.85 \\
27 \\
1.20\end{array}$ & $\begin{array}{r}3.48 \\
27 \\
.85\end{array}$ & $\begin{array}{r}3.07 \\
27 \\
1.14\end{array}$ & $\begin{array}{r}3.19 \\
27 \\
1.24\end{array}$ & $\begin{array}{r}3.37 \\
27 \\
1.18\end{array}$ & $\begin{array}{r}3.04 \\
27 \\
1.22\end{array}$ & $\begin{array}{r}2.56 \\
27 \\
1.09\end{array}$ & $\begin{array}{r}3.04 \\
27 \\
1.13\end{array}$ & $\begin{array}{r}2.89 \\
27 \\
1.15\end{array}$ & $\begin{array}{r}3.33 \\
27 \\
1.00\end{array}$ & $\begin{array}{r}2.93 \\
27 \\
1.07\end{array}$ \\
\hline Sci. & $\begin{array}{c}\mathbf{M} \\
\stackrel{\mathrm{n}}{\mathrm{SD}}\end{array}$ & $\begin{array}{r}3.25 \\
20 \\
1.16\end{array}$ & $\begin{array}{r}3.45 \\
20 \\
.94\end{array}$ & $\begin{array}{r}3.65 \\
20 \\
.88\end{array}$ & $\begin{array}{r}3.50 \\
20 \\
1.32\end{array}$ & $\begin{array}{r}3.65 \\
20 \\
.99\end{array}$ & $\begin{array}{r}3.50 \\
20 \\
1.05\end{array}$ & $\begin{array}{r}3.00 \\
20 \\
1.30\end{array}$ & $\begin{array}{r}3.15 \\
20 \\
1.09\end{array}$ & $\begin{array}{r}3.20 \\
20 \\
1.20\end{array}$ & $\begin{array}{r}3.40 \\
20 \\
1.10\end{array}$ & $\begin{array}{r}3.40 \\
20 \\
1.19\end{array}$ \\
\hline $\begin{array}{l}\text { Soc. } \\
\text { Stud. }\end{array}$ & $\begin{array}{c}\underline{\mathrm{M}} \\
\underline{\mathrm{SD}}\end{array}$ & $\begin{array}{r}3.16 \\
19 \\
1.30\end{array}$ & $\begin{array}{r}3.47 \\
19 \\
.96\end{array}$ & $\begin{array}{r}3.11 \\
19 \\
1.20\end{array}$ & $\begin{array}{r}3.26 \\
19 \\
1.45\end{array}$ & $\begin{array}{r}3.37 \\
19 \\
1.07\end{array}$ & $\begin{array}{r}3.11 \\
19 \\
1.15\end{array}$ & $\begin{array}{r}3.11 \\
19 \\
1.20\end{array}$ & $\begin{array}{r}3.37 \\
19 \\
.90\end{array}$ & $\begin{array}{r}2.84 \\
19 \\
1.07\end{array}$ & $\begin{array}{r}2.95 \\
19 \\
.85\end{array}$ & $\begin{array}{r}3.05 \\
19 \\
1.13\end{array}$ \\
\hline $\begin{array}{l}\text { Comp. } \\
\text { Lit. }\end{array}$ & $\begin{array}{c}\mathrm{M} \\
\underline{\mathrm{n}} \\
\mathrm{SD}\end{array}$ & $\begin{array}{r}3.40 \\
5 \\
1.34\end{array}$ & $\begin{array}{r}3.60 \\
5 \\
.89\end{array}$ & $\begin{array}{r}3.20 \\
5 \\
1.10\end{array}$ & $\begin{array}{r}2.60 \\
5 \\
1.34\end{array}$ & $\begin{array}{r}3.40 \\
5 \\
.89\end{array}$ & $\begin{array}{r}3.20 \\
5 \\
1.10\end{array}$ & $\begin{array}{r}2.80 \\
5 \\
1.10\end{array}$ & $\begin{array}{r}3.20 \\
5 \\
1.10\end{array}$ & $\begin{array}{r}3.60 \\
5 \\
1.52\end{array}$ & $\begin{array}{r}4.40 \\
5 \\
.55\end{array}$ & $\begin{array}{r}3.60 \\
5 \\
1.14\end{array}$ \\
\hline Total & $\begin{array}{c}\mathrm{M} \\
\underline{\mathrm{n}} \\
\underline{\mathrm{SD}}\end{array}$ & $\begin{array}{r}3.17 \\
240 \\
1.12\end{array}$ & $\begin{array}{r}3.46 \\
240 \\
.94\end{array}$ & $\begin{array}{r}3.02 \\
240 \\
1.11\end{array}$ & $\begin{array}{r}3.21 \\
240 \\
1.29\end{array}$ & $\begin{array}{r}3.43 \\
240 \\
1.04\end{array}$ & $\begin{array}{r}3.30 \\
240 \\
1.04\end{array}$ & $\begin{array}{r}2.85 \\
240 \\
1.04\end{array}$ & $\begin{array}{r}3.38 \\
240 \\
.98\end{array}$ & $\begin{array}{r}3.07 \\
240 \\
1.10\end{array}$ & $\begin{array}{r}3.13 \\
240 \\
.94\end{array}$ & $\begin{array}{r}3.23 \\
240 \\
1.07\end{array}$ \\
\hline
\end{tabular}


Table 14 shows the responses to item 22 (After participation in the teacher training, I felt that the training required by the Consent Decree was valuable). The majority of the responses appear clustered under the category of Agree and Strongly Agree for all content-areas. The majority of the remaining responses tend to be under the category of Disagree and Strongly Disagree. The results of the Chi-square test are not significant at the .05 level, $x^{2}(20, \underline{\mathrm{N}}=240)=19.37$, $\mathrm{p}=.498$. Thus, there is not enough evidence to indicate that teachers' perceptions of the teacher training required by the Consent Decree as being valuable after they participated in the training are dependent upon the content-area in which they teach.

Table 15 shows the responses to item 23 (The deadline for the completion of META teacher training was reasonable). The majority of the responses appear clustered under the category of Agree and Strongly Agree for all content-areas. The majority of the remaining responses tend to be in the Neutral category for all content-areas. The results of the Chi-square are not significant at the .5 level, $x^{2}(20, \underline{\mathrm{N}}=240)=10.61, \mathrm{p}=.956$. Thus, there is not sufficient evidence to indicate that teachers' perceptions that the deadline for completing the META teacher training was reasonable are affected by the content-area in which they teach. 
Table 14

Teachers' Perceptions of Questionnaire Item 22 by Content-area

\begin{tabular}{|c|c|c|c|c|c|c|c|c|}
\hline & $\begin{array}{l}\text { Content- } \\
\text { area }\end{array}$ & Elem. & Eng. & Math & Sci. & $\begin{array}{l}\text { Soc. } \\
\text { Stud. }\end{array}$ & $\begin{array}{r}\text { Comp. } \\
\text { Lit. }\end{array}$ & Total \\
\hline \multirow[t]{2}{*}{ S D } & Count & 11 & 2 & 5 & 2 & 3 & & 23 \\
\hline & $\begin{array}{l}\% \text { within } \\
\text { content }\end{array}$ & $7.7 \%$ & $7.4 \%$ & $18.5 \%$ & $10.0 \%$ & $15.8 \%$ & & $9.6 \%$ \\
\hline \multirow[t]{2}{*}{ D } & Count & 29 & 4 & 6 & 4 & 3 & 2 & 48 \\
\hline & $\begin{array}{l}\% \text { within } \\
\text { content }\end{array}$ & $20.4 \%$ & $14.8 \%$ & $22,2 \%$ & $20.0 \%$ & $15.8 \%$ & $40.0 \%$ & $20.0 \%$ \\
\hline \multirow[t]{2}{*}{$\mathrm{N}$} & Count & 36 & 5 & 4 & 2 & 3 & & 50 \\
\hline & $\begin{array}{l}\% \text { within } \\
\text { content }\end{array}$ & $25.4 \%$ & $18.5 \%$ & $14.8 \%$ & $10.0 \%$ & $15.8 \%$ & & $20.8 \%$ \\
\hline \multirow[t]{2}{*}{ A } & Count & 54 & 16 & 12 & 11 & 8 & 2 & 103 \\
\hline & $\begin{array}{l}\% \text { within } \\
\text { content }\end{array}$ & $38.0 \%$ & $59.3 \%$ & $44.4 \%$ & $55.5 \%$ & $42.1 \%$ & $40.0 \%$ & $42.9 \%$ \\
\hline \multirow[t]{2}{*}{ S A } & Count & 12 & & & 1 & 2 & 1 & 16 \\
\hline & $\begin{array}{l}\% \text { within } \\
\text { content }\end{array}$ & $8.5 \%$ & & & $5.0 \%$ & $10.5 \%$ & $20.0 \%$ & $6.7 \%$ \\
\hline \multirow[t]{2}{*}{ Total } & Count & 142 & 27 & 27 & 20 & 19 & 5 & 240 \\
\hline & $\begin{array}{l}\% \text { within } \\
\text { content }\end{array}$ & $100.0 \%$ & $100.0 \%$ & $100.0 \%$ & $100.0 \%$ & $100.0 \%$ & $100.0 \%$ & $100.0 \%$ \\
\hline
\end{tabular}


Table 15

Teachers' Perceptions of Questionnaire Item 23 by Content-area

\begin{tabular}{|c|c|c|c|c|c|c|c|c|}
\hline & $\begin{array}{l}\text { Content- } \\
\text { area }\end{array}$ & Elem. & Eng. & Math & Sci. & $\begin{array}{l}\text { Soc. } \\
\text { Stud. }\end{array}$ & $\frac{\text { Comp. }}{\text { Lit. }}$ & Total \\
\hline \multirow[t]{2}{*}{ SD } & Count & 9 & & 1 & 1 & 1 & & 12 \\
\hline & $\begin{array}{l}\% \text { within } \\
\text { content }\end{array}$ & $6.3 \%$ & & $3.7 \%$ & $5.0 \%$ & $5.3 \%$ & & $5.0 \%$ \\
\hline \multirow[t]{2}{*}{ D } & Count & 20 & 1 & 3 & 2 & 2 & 1 & 29 \\
\hline & $\begin{array}{l}\% \text { within } \\
\text { content }\end{array}$ & $14.1 \%$ & $3.7 \%$ & $11.1 \%$ & $10.0 \%$ & $10.5 \%$ & $20.0 \%$ & $12.1 \%$ \\
\hline \multirow[t]{2}{*}{$\mathrm{N}$} & Count & 29 & 4 & 5 & 5 & 4 & & 47 \\
\hline & $\begin{array}{l}\% \text { within } \\
\text { content }\end{array}$ & $20.4 \%$ & $14.8 \%$ & $18.5 \%$ & $25.0 \%$ & $21.1 \%$ & & $19.6 \%$ \\
\hline \multirow[t]{2}{*}{ A } & Count & 77 & 20 & 18 & 11 & 11 & 4 & 141 \\
\hline & $\begin{array}{l}\% \text { within } \\
\text { content }\end{array}$ & $54.2 \%$ & $74.1 \%$ & $66.7 \%$ & $55.0 \%$ & $57.9 \%$ & $80.0 \%$ & $58.8 \%$ \\
\hline \multirow[t]{2}{*}{ S A } & Count & 7 & 2 & & 1 & 1 & & 11 \\
\hline & $\begin{array}{l}\% \text { within } \\
\text { content }\end{array}$ & $4.9 \%$ & $7.4 \%$ & & $5.0 \%$ & $5.3 \%$ & & $4.6 \%$ \\
\hline \multirow[t]{2}{*}{ Total } & Count & 142 & 27 & 27 & 20 & 19 & 5 & 240 \\
\hline & $\begin{array}{l}\% \text { within } \\
\text { content }\end{array}$ & $100.0 \%$ & $100.0 \%$ & $100.0 \%$ & $100.0 \%$ & $100.0 \%$ & $100.0 \%$ & $100.0 \%$ \\
\hline
\end{tabular}


Table 16 shows the responses to item 24 (The number of hours of teacher training required to comply with the Consent Decree were reasonable). The majority of the responses appear clustered under the category of Agree and Strongly Agree for all content-areas. The majority of the remaining responses tend to be under the category of Disagree and Strongly Disagree. The results of the Chi-square test are not significant at the .05 level, $x^{2}(20, \underline{N}=240)=22.35$, $\mathrm{p}=.322$. Thus, there is not enough evidence to indicate that teachers' perceptions that the number of hours of teacher training required to comply with the Consent Decree was reasonable are dependent upon the content-area in which they teach.

Table 17 shows the responses to item 25 (Participation in META teacher training should be voluntary rather than mandatory). Although the majority of the responses tend to be under the category of Agree and Strongly Agree; nevertheless, there was also an emphasis on the category of Disagree and Strongly Disagree for all content-areas. The results of the Chi-square test are not significant at the .05 level, $x^{2}(20, \underline{N}=240)=13.48, p=.856$. Thus, there is not sufficient evidence to indicate that teachers' perceptions that the META teacher training should be voluntary rather than mandatory are affected by the content-area in which they teach. 
Table 16

Teachers' Perceptions of Questionnaire Item 24 by Content-area

\begin{tabular}{|c|c|c|c|c|c|c|c|c|}
\hline & $\begin{array}{l}\text { Content- } \\
\text { area }\end{array}$ & Elem. & Eng. & Math & Sci. & $\begin{array}{l}\text { Soc. } \\
\text { Stud. }\end{array}$ & $\begin{array}{r}\text { Comp. } \\
\text { Lit. }\end{array}$ & Total \\
\hline \multirow[t]{2}{*}{ SD } & Count & 17 & 2 & 3 & 1 & 3 & & 26 \\
\hline & $\begin{array}{l}\% \text { within } \\
\text { content }\end{array}$ & $12.0 \%$ & $7.4 \%$ & $11.1 \%$ & $5.0 \%$ & $15.8 \%$ & & $10.8 \%$ \\
\hline \multirow[t]{2}{*}{$\mathrm{D}$} & Count & 40 & 6 & 6 & 1 & 3 & 2 & 58 \\
\hline & $\begin{array}{l}\% \text { within } \\
\text { content }\end{array}$ & $28.2 \%$ & $22.2 \%$ & $22.2 \%$ & $5.0 \%$ & $15.8 \%$ & $40.0 \%$ & $24.2 \%$ \\
\hline \multirow[t]{2}{*}{$\mathrm{N}$} & Count & 35 & 4 & 5 & 3 & 2 & & 49 \\
\hline & $\begin{array}{l}\% \text { within } \\
\text { content }\end{array}$ & $24.6 \%$ & $14.8 \%$ & $18.5 \%$ & $15.0 \%$ & $10.5 \%$ & & $20.4 \%$ \\
\hline \multirow[t]{2}{*}{ A } & Count & 46 & 13 & 12 & 14 & 11 & 3 & 99 \\
\hline & $\begin{array}{l}\% \text { within } \\
\text { content }\end{array}$ & $32.4 \%$ & $48.1 \%$ & $44.4 \%$ & $70.0 \%$ & $57.9 \%$ & $60.0 \%$ & $41.3 \%$ \\
\hline \multirow[t]{2}{*}{ S A } & Count & 4 & 2 & 1 & 1 & & & 8 \\
\hline & $\begin{array}{l}\% \text { within } \\
\text { content }\end{array}$ & $2.8 \%$ & $7.4 \%$ & $3.7 \%$ & $5.0 \%$ & & & $3.3 \%$ \\
\hline \multirow[t]{2}{*}{ Total } & Count & 142 & 27 & 27 & 20 & 19 & 5 & 240 \\
\hline & $\begin{array}{l}\% \text { within } \\
\text { content }\end{array}$ & $100.0 \%$ & $100.0 \%$ & $100.0 \%$ & $100.0 \%$ & $100.0 \%$ & $100.0 \%$ & $100.0 \%$ \\
\hline
\end{tabular}


Table 17

Teachers' Perceptions of Questionnaire Item 25 by Content-area

\begin{tabular}{|c|c|c|c|c|c|c|c|c|}
\hline & $\begin{array}{l}\text { Content- } \\
\text { area }\end{array}$ & Elem. & Eng. & Math & Sci. & $\begin{array}{l}\text { Soc. } \\
\text { Stud. }\end{array}$ & $\begin{array}{r}\text { Comp. } \\
\text { Lit. }\end{array}$ & Total \\
\hline \multirow[t]{2}{*}{$\mathrm{SD}$} & Count & 11 & 3 & 1 & 2 & 2 & 1 & 20 \\
\hline & $\begin{array}{l}\% \text { within } \\
\text { content }\end{array}$ & $7.7 \%$ & $11.1 \%$ & $3.7 \%$ & $10.0 \%$ & $10.5 \%$ & $20.0 \%$ & $8.3 \%$ \\
\hline \multirow[t]{2}{*}{ D } & Count & 38 & 12 & 10 & 3 & 6 & 2 & 71 \\
\hline & $\begin{array}{l}\% \text { within } \\
\text { content }\end{array}$ & $26.8 \%$ & $44.4 \%$ & $37.0 \%$ & $15.0 \%$ & $31.6 \%$ & $40.0 \%$ & $29.6 \%$ \\
\hline \multirow[t]{2}{*}{$\mathrm{N}$} & Count & 22 & 4 & 4 & 3 & 1 & & 34 \\
\hline & $\begin{array}{l}\% \text { within } \\
\text { content }\end{array}$ & $15.5 \%$ & $14.8 \%$ & $14.8 \%$ & $15.0 \%$ & $5.3 \%$ & & $14.2 \%$ \\
\hline \multirow[t]{2}{*}{ A } & Count & 41 & 6 & 7 & 7 & 5 & 2 & 68 \\
\hline & $\begin{array}{l}\% \text { within } \\
\text { content }\end{array}$ & $28.9 \%$ & $22.2 \%$ & $25.9 \%$ & $35.0 \%$ & $26.3 \%$ & $40.0 \%$ & $28.3 \%$ \\
\hline \multirow[t]{2}{*}{ SA } & Count & 30 & 2 & 5 & 5 & 5 & & 47 \\
\hline & $\begin{array}{l}\% \text { within } \\
\text { content }\end{array}$ & $21.1 \%$ & $7.4 \%$ & $18.5 \%$ & $25.0 \%$ & $26.3 \%$ & & $19.6 \%$ \\
\hline \multirow[t]{2}{*}{ Total } & Count & 142 & 27 & 27 & 20 & 19 & 5 & 240 \\
\hline & $\begin{array}{l}\% \text { within } \\
\text { content }\end{array}$ & $100.0 \%$ & $100.0 \%$ & $100.0 \%$ & $100.0 \%$ & $100.0 \%$ & $100.0 \%$ & $100.0 \%$ \\
\hline
\end{tabular}


Table 18 shows the responses to item 26 (The teacher training required through the Consent Decree provided an opportunity for professional growth). The majority of the responses appear clustered under the category of Agree and Strongly Agree for all content-areas. The majority of the remaining responses tend to be in the Neutral category for all content-areas except for Mathematics and Science, where they also tend to rate the item either Disagree or Strongly Disagree. The results of the Chi-square test are not significant at the .05 level, $x^{2}$ $(20, \underline{N}=240)=10.16, p=.965$. Thus, there is not enough evidence to indicate that teachers' perceptions concerning whether the teacher training required through the Consent Decree provided them with an opportunity for professional growth are dependent upon the content-area in which they teach.

Table 19 shows the responses to item 27 (The teacher training mandated by the Consent Decree was beneficial). The majority of the responses appear under the category of Agree and Strongly Agree for all content-areas. The remaining responses appear evenly divided between the category of Neutral and the category of Disagree and Strongly Disagree for all content-areas. The results of the Chi-square are not significant at the .05 level, $x^{2}(20, \underline{N}=240)=20.34, p=$ .437. Thus, there is not sufficient evidence to indicate that teachers' perceptions concerning whether the teacher training mandated by the Consent Decree was beneficial are affected by the content-area in which they teach. 
Table 18

Teachers' Perceptions of Questionnaire Item 26 by Content-area

\begin{tabular}{|c|c|c|c|c|c|c|c|c|}
\hline & $\begin{array}{l}\text { Content- } \\
\text { area }\end{array}$ & Elem. & Eng. & Math & Sci. & $\begin{array}{l}\text { Soc. } \\
\text { Stud. }\end{array}$ & $\begin{array}{r}\text { Comp. } \\
\text { Lit. }\end{array}$ & Total \\
\hline \multirow[t]{2}{*}{ S D } & Count & 9 & 2 & 3 & 1 & 2 & & 17 \\
\hline & $\begin{array}{l}\% \text { within } \\
\text { content }\end{array}$ & $6.3 \%$ & $7.4 \%$ & $11.1 \%$ & $5.0 \%$ & $10.5 \%$ & & $7.1 \%$ \\
\hline \multirow[t]{2}{*}{$\mathrm{D}$} & Count & 19 & 1 & 3 & 2 & 1 & 1 & 27 \\
\hline & $\begin{array}{l}\% \text { within } \\
\text { content }\end{array}$ & $13.4 \%$ & $3.7 \%$ & $11.1 \%$ & $10.0 \%$ & $5.3 \%$ & $20.0 \%$ & $11.3 \%$ \\
\hline \multirow[t]{2}{*}{$\mathrm{N}$} & Count & 34 & 7 & 5 & 2 & 5 & 1 & 54 \\
\hline & $\begin{array}{l}\% \text { within } \\
\text { content }\end{array}$ & $23.9 \%$ & $25.9 \%$ & $18.5 \%$ & $10.0 \%$ & $26.3 \%$ & $20.0 \%$ & $22.5 \%$ \\
\hline \multirow[t]{2}{*}{ A } & Count & 66 & 16 & 13 & 13 & 10 & 3 & 121 \\
\hline & $\begin{array}{l}\% \text { within } \\
\text { content }\end{array}$ & $46.5 \%$ & $59.3 \%$ & $48.1 \%$ & $65.0 \%$ & $52.6 \%$ & $60.0 \%$ & $50.4 \%$ \\
\hline \multirow[t]{2}{*}{ S A } & Count & 14 & 1 & 3 & 2 & 1 & & 21 \\
\hline & $\begin{array}{l}\% \text { within } \\
\text { content }\end{array}$ & $9.9 \%$ & $3.7 \%$ & $11.1 \%$ & $10.0 \%$ & $5.3 \%$ & & $8.8 \%$ \\
\hline \multirow[t]{2}{*}{ Total } & Count & 142 & 27 & 27 & 20 & 19 & 5 & 240 \\
\hline & $\begin{array}{l}\% \text { within } \\
\text { content }\end{array}$ & $100.0 \%$ & $100.0 \%$ & $100.0 \%$ & $100.0 \%$ & $100.0 \%$ & $100.0 \%$ & $100.0 \%$ \\
\hline
\end{tabular}


Table 19

Teachers' Perceptions of Questionnaire Item 27 by Content-area

\begin{tabular}{|c|c|c|c|c|c|c|c|c|}
\hline & $\begin{array}{l}\text { Content- } \\
\text { area }\end{array}$ & Elem. & Eng. & Math & Sci. & $\begin{array}{l}\text { Soc. } \\
\text { Stud. }\end{array}$ & $\begin{array}{r}\text { Comp. } \\
\text { Lit. }\end{array}$ & Total \\
\hline \multirow[t]{2}{*}{ SD } & Count & 8 & 1 & 4 & 2 & 3 & & 18 \\
\hline & $\begin{array}{l}\% \text { within } \\
\text { content }\end{array}$ & $5.6 \%$ & $3.7 \%$ & $14.8 \%$ & $10.0 \%$ & $15.8 \%$ & & $7.5 \%$ \\
\hline \multirow[t]{2}{*}{$\mathrm{D}$} & Count & 22 & 3 & 6 & 1 & 2 & 2 & 36 \\
\hline & $\begin{array}{l}\% \text { within } \\
\text { content }\end{array}$ & $15.5 \%$ & $11.1 \%$ & $22.2 \%$ & $5.0 \%$ & $10.5 \%$ & $40.0 \%$ & $15.0 \%$ \\
\hline \multirow[t]{2}{*}{$\mathrm{N}$} & Count & 40 & 5 & 3 & 3 & 4 & & 55 \\
\hline & $\begin{array}{l}\% \text { within } \\
\text { content }\end{array}$ & $28.2 \%$ & $18.5 \%$ & $11.1 \%$ & $15.0 \%$ & $21.1 \%$ & & $22.9 \%$ \\
\hline \multirow[t]{2}{*}{ A } & Count & 62 & 16 & 13 & 13 & 10 & 3 & 117 \\
\hline & $\begin{array}{l}\% \text { within } \\
\text { content }\end{array}$ & $43.7 \%$ & $59.3 \%$ & $48.1 \%$ & $65.0 \%$ & $52.6 \%$ & $60.0 \%$ & $48.8 \%$ \\
\hline \multirow[t]{2}{*}{ S A } & Count & 10 & 2 & 1 & 1 & & & 14 \\
\hline & $\begin{array}{l}\% \text { within } \\
\text { content }\end{array}$ & $7.0 \%$ & $7.4 \%$ & $3.7 \%$ & $5.0 \%$ & & & $5.8 \%$ \\
\hline \multirow[t]{2}{*}{ Total } & Count & 142 & 27 & 27 & 20 & 19 & 5 & 240 \\
\hline & $\begin{array}{l}\% \text { within } \\
\text { content }\end{array}$ & $100.0 \%$ & $100.0 \%$ & $100.0 \%$ & $100.0 \%$ & $100.0 \%$ & $100.0 \%$ & $100.0 \%$ \\
\hline
\end{tabular}


Table 20 shows the responses to item 28 (The teacher training mandated by the Consent Decree took the teachers' perspectives into consideration in its development). The majority of the responses appear divided among Disagree, Neutral, and Agree for all content-areas. The majority of the remaining responses tend to be under Strongly Disagree. The results of the Chi-square test are not significant at the .05 level, $x^{2}(20, \underline{\mathrm{N}}=240)=24.49, \mathrm{p}=.222$. Thus, there is not enough evidence to indicate that teachers' perceptions concerning whether the teacher training mandated by the Consent Decree took their perspectives into consideration in its development are dependent upon the content-area in which they teach.

Table 21 shows the responses to item 29 (After participation in the META teacher training I felt I had knowledge of the legal basis for the training). The majority of the responses appear clustered under Agree for all content-areas. The majority of the remaining responses appear under the category of Disagree and Strongly Disagree for all content-areas; although there is also an emphasis on Neutral. The results of the Chi-square test are not significant at the .05 level, $x^{2}$ $(20, \underline{N}=240)=17.33, p=.632$. Thus, there is not sufficient evidence to indicate that teachers' perceptions of having knowledge of the legal basis for the training after participating in the META teacher training are affected by the content-area in which they teach. 
Table 20

Teachers' Perceptions of Questionnaire Item 28 by Content-area

\begin{tabular}{|c|c|c|c|c|c|c|c|c|}
\hline & $\begin{array}{l}\text { Content- } \\
\text { area }\end{array}$ & Elem. & Eng. & Math & Sci. & $\begin{array}{l}\text { Soc. } \\
\text { Stud. }\end{array}$ & $\begin{array}{c}\text { Comp. } \\
\text { Lit. }\end{array}$ & Total \\
\hline \multirow[t]{2}{*}{ SD } & Count & 14 & & 5 & 3 & 2 & & 24 \\
\hline & $\begin{array}{l}\% \text { within } \\
\text { content }\end{array}$ & $9.9 \%$ & & $18.5 \%$ & $15.0 \%$ & $10.5 \%$ & & $10.0 \%$ \\
\hline \multirow[t]{2}{*}{ D } & Count & 39 & 8 & 9 & 5 & 5 & 3 & 69 \\
\hline & $\begin{array}{l}\% \text { within } \\
\text { content }\end{array}$ & $27.5 \%$ & $29.6 \%$ & $33.3 \%$ & $25.0 \%$ & $26.3 \%$ & $60.0 \%$ & $28.8 \%$ \\
\hline \multirow[t]{2}{*}{$\mathrm{N}$} & Count & 51 & 11 & 6 & 3 & 2 & & 73 \\
\hline & $\begin{array}{l}\% \text { within } \\
\text { content }\end{array}$ & $35.9 \%$ & $40.7 \%$ & $22.2 \%$ & $15.0 \%$ & $10.5 \%$ & & $30.4 \%$ \\
\hline \multirow[t]{2}{*}{ A } & Count & 34 & 7 & 7 & 7 & 9 & 2 & 66 \\
\hline & $\begin{array}{l}\% \text { within } \\
\text { content }\end{array}$ & $23.9 \%$ & $25.9 \%$ & $25.9 \%$ & $35.0 \%$ & $47.4 \%$ & $40.0 \%$ & $27.5 \%$ \\
\hline \multirow[t]{2}{*}{ S A } & Count & 4 & 1 & & 2 & 1 & & 8 \\
\hline & $\begin{array}{l}\% \text { within } \\
\text { content }\end{array}$ & $2.8 \%$ & $3.7 \%$ & & $10.0 \%$ & $5.3 \%$ & & $3.3 \%$ \\
\hline \multirow[t]{2}{*}{ Total } & Count & 142 & 27 & 27 & 20 & 19 & 5 & 240 \\
\hline & $\begin{array}{l}\% \text { within } \\
\text { content }\end{array}$ & $100.0 \%$ & $100.0 \%$ & $100.0 \%$ & $100.0 \%$ & $100.0 \%$ & $100.0 \%$ & $100.0 \%$ \\
\hline
\end{tabular}


Table 21

Teachers' Perceptions of Questionnaire Item 29 by Content-area

\begin{tabular}{|c|c|c|c|c|c|c|c|c|}
\hline & $\begin{array}{l}\text { Content- } \\
\text { area }\end{array}$ & Elem. & Eng. & Math & Sci. & $\begin{array}{l}\text { Soc. } \\
\text { Stud. }\end{array}$ & $\begin{array}{c}\text { Comp. } \\
\text { Lit. }\end{array}$ & Total \\
\hline \multirow[t]{2}{*}{ S D } & Count & 6 & 2 & 3 & 1 & 1 & & 13 \\
\hline & $\begin{array}{l}\% \text { within } \\
\text { content }\end{array}$ & $4.2 \%$ & $7.4 \%$ & $11.1 \%$ & $5.0 \%$ & $5.3 \%$ & & $5.4 \%$ \\
\hline \multirow[t]{2}{*}{ D } & Count & 16 & 5 & 7 & 6 & 2 & 2 & 38 \\
\hline & $\begin{array}{l}\% \text { within } \\
\text { content }\end{array}$ & $11.3 \%$ & $18.5 \%$ & $25.9 \%$ & $30.0 \%$ & $10.5 \%$ & $40.0 \%$ & $15.5 \%$ \\
\hline \multirow[t]{2}{*}{$\mathrm{N}$} & Count & 27 & 5 & 3 & 3 & 5 & & 43 \\
\hline & $\begin{array}{l}\% \text { within } \\
\text { content }\end{array}$ & $19.0 \%$ & $18.5 \%$ & $11.1 \%$ & $15.0 \%$ & $26.3 \%$ & & $17.9 \%$ \\
\hline \multirow[t]{2}{*}{ A } & Count & 85 & 14 & 14 & 9 & 11 & 3 & 136 \\
\hline & $\begin{array}{l}\% \text { within } \\
\text { content }\end{array}$ & $59.9 \%$ & $51.9 \%$ & $51.9 \%$ & $45.0 \%$ & $57.9 \%$ & $60.0 \%$ & $56.7 \%$ \\
\hline \multirow[t]{2}{*}{ S A } & Count & 8 & 1 & & 1 & & & 10 \\
\hline & $\begin{array}{l}\% \text { within } \\
\text { content }\end{array}$ & $5.6 \%$ & $3.7 \%$ & & $5.0 \%$ & & & $4.2 \%$ \\
\hline \multirow[t]{2}{*}{ Total } & Count & 142 & 27 & 27 & 20 & 19 & 5 & 240 \\
\hline & $\begin{array}{l}\% \text { within } \\
\text { content }\end{array}$ & $100.0 \%$ & $100.0 \%$ & $100.0 \%$ & $100.0 \%$ & $100.0 \%$ & $100.0 \%$ & $100.0 \%$ \\
\hline
\end{tabular}


Table 22 shows the responses to item 30 (The Consent Decree was a necessary piece of legislation). The majority of the responses appear clustered under Agree for all content-areas except for Elementary, where there is an emphasis on Neutral. The significance level of the Chi-square test is .49, indicating that the results of the Chi-square test performed on the data are significant at the .05 level, $x^{2}(20, \underline{N}=240)=31.5, p=.049$. Thus, there may be a relationship between the content-area of the teachers and their perceptions concerning whether the Consent Decree was a necessary piece of legislation.

Table 23 shows the responses to item 31 (Prior to participation in META teacher training, I thought the training had limited value). The majority of the responses appear divided between Disagree, Neutral, and Agree for all content-areas. Elementary, English, and Social Studies teachers tended to emphasize Neutral; whereas, Mathematics and Social Studies teachers tended to emphasize Agree. The results of the Chi-square test are not significant at the .05 level, $x^{2}(20, \underline{\mathrm{N}}=240)=31.17, \mathrm{p}=.053$. Thus, there is not enough evidence to indicate that teachers' perceptions concerning whether the training had limited value prior to their participating in the META teacher training are dependent upon the content-area in which they teach. 
Table 22

Teachers' Perceptions of Questionnaire Item 30 by Content-area

\begin{tabular}{|c|c|c|c|c|c|c|c|c|}
\hline & $\begin{array}{l}\text { Content: } \\
\text { area }\end{array}$ & Elem. & Eng. & Math & Sci. & $\begin{array}{l}\text { Soc. } \\
\text { Stud. }\end{array}$ & $\begin{array}{r}\text { Comp. } \\
\text { Lit }\end{array}$ & Total \\
\hline \multirow[t]{2}{*}{ S D } & Count & 13 & 3 & 4 & 3 & 2 & & 25 \\
\hline & $\begin{array}{l}\% \text { within } \\
\text { content }\end{array}$ & $9.2 \%$ & $11.1 \%$ & $14.8 \%$ & $15.0 \%$ & $10.5 \%$ & & $10.4 \%$ \\
\hline \multirow[t]{2}{*}{ D } & Count & 29 & 2 & 7 & 2 & 6 & 2 & 48 \\
\hline & $\begin{array}{l}\% \text { within } \\
\text { content }\end{array}$ & $20.4 \%$ & $7.4 \%$ & $25.9 \%$ & $10.0 \%$ & $31.6 \%$ & $40.0 \%$ & $20.0 \%$ \\
\hline \multirow[t]{2}{*}{$\mathrm{N}$} & Count & 47 & 7 & 4 & 4 & 4 & & 66 \\
\hline & $\begin{array}{l}\% \text { within } \\
\text { content }\end{array}$ & $33.1 \%$ & $25.9 \%$ & $14.8 \%$ & $20.0 \%$ & $21.1 \%$ & & $27.5 \%$ \\
\hline \multirow[t]{2}{*}{ A } & Count & 44 & 14 & 12 & 10 & 7 & 1 & 88 \\
\hline & $\begin{array}{l}\% \text { within } \\
\text { content }\end{array}$ & $31.0 \%$ & $51.9 \%$ & $44.4 \%$ & $50.0 \%$ & $36.8 \%$ & $20.0 \%$ & $36.7 \%$ \\
\hline \multirow[t]{2}{*}{ S A } & Count & 9 & 1 & & 1 & & 2 & 13 \\
\hline & $\begin{array}{l}\% \text { within } \\
\text { content }\end{array}$ & $6.3 \%$ & $3.7 \%$ & & $5.0 \%$ & & $40.0 \%$ & $5.4 \%$ \\
\hline \multirow[t]{2}{*}{ Total } & Count & 142 & 27 & 27 & 20 & 19 & 5 & 240 \\
\hline & $\begin{array}{l}\% \text { within } \\
\text { content }\end{array}$ & $100.0 \%$ & $100.0 \%$ & $100.0 \%$ & $100.0 \%$ & $100.0 \%$ & $100.0 \%$ & $100.0 \%$ \\
\hline
\end{tabular}


Table 23

Teachers' Perceptions of Questionnaire Item 31 by Content-area

\begin{tabular}{|c|c|c|c|c|c|c|c|c|}
\hline & $\begin{array}{l}\text { Content- } \\
\text { area }\end{array}$ & Elem. & Eng. & Math & Sci. & $\begin{array}{r}\text { Soc. } \\
\text { Stud. }\end{array}$ & $\begin{array}{r}\text { Comp. } \\
\text { Lit. }\end{array}$ & Total \\
\hline \multirow[t]{2}{*}{ SD } & Count & 6 & & & 1 & 1 & & 8 \\
\hline & $\begin{array}{l}\% \text { within } \\
\text { content }\end{array}$ & $4.2 \%$ & & & $5.0 \%$ & $5.0 \%$ & & $3.3 \%$ \\
\hline \multirow[t]{2}{*}{$D$} & Count & 32 & 7 & 7 & 4 & 4 & & 54 \\
\hline & $\begin{array}{l}\% \text { within } \\
\text { content }\end{array}$ & $22.5 \%$ & $25.9 \%$ & $25.9 \%$ & $20.0 \%$ & $21.1 \%$ & & $22.5 \%$ \\
\hline \multirow[t]{2}{*}{$\mathrm{N}$} & Count & 58 & 13 & 7 & 3 & 9 & & 90 \\
\hline & $\begin{array}{l}\% \text { within } \\
\text { content }\end{array}$ & $40.8 \%$ & $48.1 \%$ & $25.9 \%$ & $15.0 \%$ & $47.4 \%$ & & $37.5 \%$ \\
\hline \multirow[t]{2}{*}{ A } & Count & 39 & 7 & 10 & 10 & 5 & 3 & 74 \\
\hline & $\begin{array}{l}\% \text { within } \\
\text { content }\end{array}$ & $27.5 \%$ & $25.9 \%$ & $37.0 \%$ & $50.0 \%$ & $26.3 \%$ & $60.0 \%$ & $30.8 \%$ \\
\hline \multirow{2}{*}{$\mathrm{SA}$} & Count & 7 & & 3 & 2 & & 2 & 14 \\
\hline & $\begin{array}{l}\% \text { within } \\
\text { content }\end{array}$ & $4.9 \%$ & & $11.1 \%$ & $10.0 \%$ & & $40.0 \%$ & $5.8 \%$ \\
\hline \multirow[t]{2}{*}{ Total } & $\begin{array}{l}\text { Count } \\
\% \text { within }\end{array}$ & 142 & 27 & 27 & 20 & 19 & 5 & 240 \\
\hline & content & $100.0 \%$ & $100.0 \%$ & $100.0 \%$ & $100.0 \%$ & $100.0 \%$ & $100.0 \%$ & $100.0 \%$ \\
\hline
\end{tabular}

Table 24 shows the responses to item 32 (After participation in META teacher training, I realized the importance of the training). The majority of the responses appear clustered under Agree for all content-areas. The majority of the remaining responses appear divided between the category of Disagree and 
Strongly Disagree and the category of Neutral for all content-areas. The results of the Chi-square test are not significant at the .05 level, $x^{2}(20, \underline{N}=240)=15.83$, $\mathrm{p}=.727$. Thus, there is not sufficient evidence to indicate that teachers' perceptions of the importance of the training once they participated in the META teacher training are affected by the content-area in which teach.

Table 24

Teachers' Perceptions of Questionnaire Item 32 by Content-area

\begin{tabular}{|c|c|c|c|c|c|c|c|c|}
\hline & $\begin{array}{l}\text { Content- } \\
\text { area }\end{array}$ & Elem. & Eng. & Math & Sci. & $\begin{array}{l}\text { Soc. } \\
\text { Stud. }\end{array}$ & $\begin{array}{r}\text { Comp. } \\
\text { Lit. }\end{array}$ & Total \\
\hline \multirow[t]{2}{*}{ S D } & Count & 10 & 1 & 3 & 3 & 3 & & 20 \\
\hline & $\begin{array}{l}\% \text { within } \\
\text { content }\end{array}$ & $7.0 \%$ & $3.7 \%$ & $11.1 \%$ & $15.0 \%$ & $15.8 \%$ & & $8.3 \%$ \\
\hline \multirow[t]{2}{*}{$\mathrm{D}$} & Count & 27 & 5 & 7 & 1 & 2 & 1 & 43 \\
\hline & $\begin{array}{l}\% \text { within } \\
\text { content }\end{array}$ & $19.0 \%$ & $18.5 \%$ & $25.9 \%$ & $5.0 \%$ & $10.5 \%$ & $20.0 \%$ & $17.9 \%$ \\
\hline \multirow[t]{2}{*}{$\mathrm{N}$} & Count & 30 & 6 & 6 & 2 & 5 & 1 & 50 \\
\hline & $\begin{array}{l}\% \text { within } \\
\text { content }\end{array}$ & $21.1 \%$ & $22.2 \%$ & $22.2 \%$ & $10.0 \%$ & $26.3 \%$ & $20.0 \%$ & $20.8 \%$ \\
\hline \multirow[t]{2}{*}{ A } & Count & 66 & 14 & 11 & 13 & 9 & 2 & 115 \\
\hline & $\begin{array}{l}\% \text { within } \\
\text { content }\end{array}$ & $46.5 \%$ & $51.9 \%$ & $40.7 \%$ & $65.0 \%$ & $47.4 \%$ & $40.0 \%$ & $47.9 \%$ \\
\hline \multirow[t]{2}{*}{ SA } & Count & 9 & 1 & & 1 & & 1 & 12 \\
\hline & $\begin{array}{l}\% \text { within } \\
\text { content }\end{array}$ & $6.3 \%$ & $3.7 \%$ & & $5.0 \%$ & & $20.0 \%$ & $5.0 \%$ \\
\hline \multirow[t]{2}{*}{ Total } & Count & 142 & 27 & 27 & 20 & 19 & 5 & 240 \\
\hline & $\begin{array}{l}\% \text { within } \\
\text { content }\end{array}$ & $100.0 \%$ & $100.0 \%$ & $100.0 \%$ & $100.0 \%$ & $100.0 \%$ & $100.0 \%$ & $100.0 \%$ \\
\hline
\end{tabular}


Subsidiary Question Three: What changes are perceived to have occurred in the content-area teachers' instructional practices as a result of the training?

Table 25 reports the means and the standard deviations of the responses to items 33 through 43 by content-area. The means for the responses to items 33 through 39 and item 43 range between Neutral and Agree for all content-areas. More specifically, the lowest overall mean for the six content-areas was found on item 36 , at 2.97 , and the highest overall mean was found on item 41 , at 3.93 . The means for the responses to item 40 (The META teacher training provided follow-up to guide me in incorporating second language instructional strategies into my particular situation) and the means for the responses to item 42 (After the META training, I felt motivated to change my teaching style) appear to range between Disagree and Neutral. More specifically, the lowest overall mean for the six content-areas was found on item 42 , at 2.78 , and the highest overall mean was found on item 40 , at 2.91 .

Tables 26 through 36 show how the content-area teachers responded to the individual survey items using the Likert scale. The tables show both the total number of content-area teachers and these teachers divided by content-area. For clarity of discussion, rather than present the number of responses in each Likert scale category, the five categories will be collapsed into three categories as follows: 1) Strongly Disagree and Disagree, 2) Neutral, and 3) Agree and Strongly Agree. This procedure will be followed throughout the analyses unless it is more appropriate to discuss as distinct responses. 
Table 25

Means and Standard Deviations of Questionnaire Items 33 through 43

by Content-area

\begin{tabular}{lrrrrrrrrrrrrr}
\hline Con- & & Item & Item & Item & Item & Item & Item & Item & Item & Item & Item & Item \\
tent & & $\underline{\mathbf{3 3}}$ & $\mathbf{3 4}$ & $\mathbf{3 5}$ & $\mathbf{3 6}$ & $\underline{\mathbf{3 7}}$ & $\mathbf{3 8}$ & $\mathbf{3 9}$ & $\mathbf{4 0}$ & $\mathbf{4 1}$ & $\mathbf{4 2}$ & $\mathbf{4 3}$ \\
Elem. & $\mathrm{M}$ & $\mathbf{3 . 5 6}$ & 3.61 & 3.49 & 2.87 & 3.16 & 3.75 & 3.33 & 3.00 & 4.06 & 2.75 & 3.20 \\
& $\mathrm{~N}$ & 142 & 142 & 142 & 142 & 142 & 142 & 142 & 142 & 142 & $\mathbf{1 4 2}$ & 142 \\
& $\mathrm{SD}$ & .90 & .84 & .92 & 1.00 & 1.02 & .85 & .94 & 1.01 & .70 & .96 & 1.03 \\
& & & & & & & & & & & & \\
Eng. & $\mathbf{M}$ & 3.52 & 3.41 & 3.52 & 3.30 & 3.30 & 3.78 & 3.41 & 3.00 & 4.15 & 3.04 & 3.56 \\
& $\mathbf{N}$ & 27 & 27 & 27 & 27 & 27 & 27 & 27 & 27 & 27 & 27 & 27 \\
& $\underline{\mathrm{SD}}$ & .58 & .97 & .89 & .87 & .87 & .58 & .75 & 1.04 & .66 & 1.06 & .80
\end{tabular}

$\begin{array}{lrrrrrrrrrrrr}\text { Math. } & \text { M } & 3.11 & 3.30 & 3.22 & 2.85 & 2.93 & 3.52 & 2.96 & 2.44 & 3.19 & 2.52 & 2.93 \\ & \text { N } & 27 & 27 & 27 & 27 & 27 & 27 & 27 & 27 & 27 & 27 & 27 \\ & \text { SD } & 1.09 & 1.03 & 1.05 & 1.13 & 1.14 & .85 & 1.22 & 1.09 & 1.11 & 1.05 & 1.07\end{array}$

$\begin{array}{rrrrrrrrrrrrr}\text { Sci. } & \mathrm{M} & 3.35 & 3.10 & 3.55 & 3.30 & 3.30 & 3.55 & 3.15 & 3.00 & 3.90 & 3.10 & 3.25 \\ & \mathrm{~N} & 20 & 20 & 20 & 20 & 20 & 20 & 20 & 20 & 20 & 20 & 20 \\ & \mathrm{SD} & .93 & .97 & .83 & 1.30 & 1.22 & .76 & 1.04 & 1.03 & .72 & 1.17 & 1.12\end{array}$

$\begin{array}{lllllllllllll}\text { Soc. } & \mathrm{M} & 3.05 & 3.37 & 3.47 & 3.00 & 3.05 & 3.32 & 3.21 & 2.84 & 3.79 & 2.63 & 3.26\end{array}$

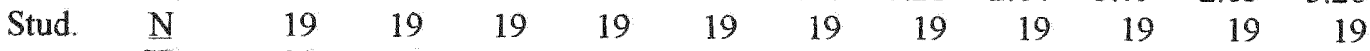

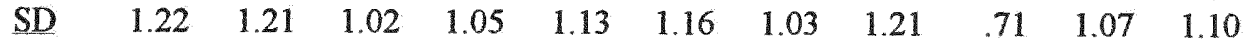

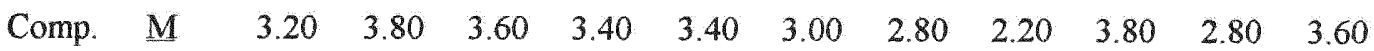

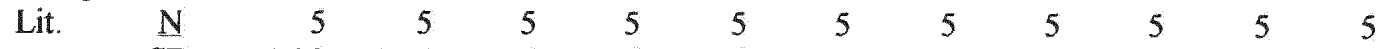

$\begin{array}{llllllllllll}\text { SD } & 1.30 & 1.30 & 1.14 & 1.34 & 1.34 & 1.41 & 1.10 & 1.10 & 1.10 & 1.10 & .89\end{array}$

$\begin{array}{lllllllllllll}\text { Total } & \mathrm{M} & 3.44 & 3.50 & 3.47 & 2.97 & 3.16 & 3.66 & 3.26 & 2.91 & 3.93 & 2.78 & 3.23\end{array}$

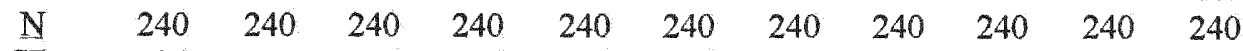

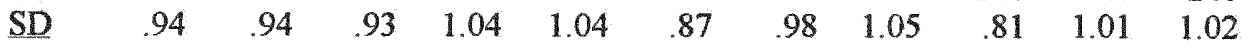


Table 26 shows the responses for item 33 (After the META teacher training, I feel competent using second language instructional strategies in the content-area classroom). The majority of the responses appear clustered under the category of Agree and Strongly Agree for all content-areas. The majority of the remaining responses tend to be under the Neutral category for all content-areas except Social Studies and Computer Literacy, where the emphasis is on Disagree. The significance level of the Chi-square test is .028 indicating that the results of the Chi-square test performed on the data are significant at the .05 level, $x^{2}(20, \mathrm{~N}=240)=33.79, \mathrm{p}=.028$. Thus, there appears to be a relationship between the content-area of the teachers and their perceptions concerning whether after the META teacher training, they feel competent using second language instructional strategies in the content-area classroom.

Table 27 shows the responses to item 34 (Second language instructional strategies are easy to implement within the content-area classroom setting). The majority of the responses appear clustered under the Category of Agree and Strongly Agree for all content-areas. The majority of the remaining responses appear divided between the category of Disagree and Strongly Disagree and the category of Neutral for all content-areas. The results of the Chi-square test are not significant at the .05 level, $x^{2}(20, \underline{N}=240)=25.67, p=.177$. Thus, there is not enough evidence to indicate that teachers' perceptions concerning whether they find second language instructional strategies easy to implement within the content-area classroom setting are dependent upon the content-area in which they teach. 
Table 26

Teachers' Perceptions of Questionnaire Item 33 by Content-area

\begin{tabular}{|c|c|c|c|c|c|c|c|c|}
\hline & $\begin{array}{l}\text { Content- } \\
\text { area }\end{array}$ & Elem. & Eng. & Math & Sci. & $\begin{array}{l}\text { Soc. } \\
\text { Stud. }\end{array}$ & $\begin{array}{r}\text { Comp. } \\
\text { Lit. }\end{array}$ & Total \\
\hline \multirow[t]{2}{*}{ SD } & Count & 4 & & 3 & 1 & 1 & & 9 \\
\hline & $\begin{array}{l}\% \text { within } \\
\text { content }\end{array}$ & $2.8 \%$ & & $11.1 \%$ & $5.0 \%$ & $5.3 \%$ & & $3.8 \%$ \\
\hline \multirow[t]{2}{*}{ D } & Count & 13 & 1 & 4 & 2 & 7 & 2 & 29 \\
\hline & $\begin{array}{l}\% \text { within } \\
\text { content }\end{array}$ & $9.2 \%$ & $3.7 \%$ & $14.8 \%$ & $10.0 \%$ & $36.8 \%$ & $40.0 \%$ & $12.1 \%$ \\
\hline \multirow[t]{2}{*}{$\mathrm{N}$} & Count & 39 & 11 & 8 & 7 & 4 & 1 & 70 \\
\hline & $\begin{array}{l}\% \text { within } \\
\text { content }\end{array}$ & $27.5 \%$ & $40.7 \%$ & $29.6 \%$ & $35.0 \%$ & $21.1 \%$ & $20.0 \%$ & $29.2 \%$ \\
\hline \multirow[t]{2}{*}{ A } & Count & 72 & 15 & 11 & 9 & 4 & 1 & 112 \\
\hline & $\begin{array}{l}\% \text { within } \\
\text { content }\end{array}$ & $50.7 \%$ & $55.6 \%$ & $40.7 \%$ & $45.0 \%$ & $21.1 \%$ & $20.0 \%$ & $46.7 \%$ \\
\hline \multirow[t]{2}{*}{ S A } & Count & 14 & & 1 & 1 & 3 & 1 & 20 \\
\hline & $\begin{array}{l}\% \text { within } \\
\text { content }\end{array}$ & $9.9 \%$ & & $3.7 \%$ & $5.0 \%$ & $15.8 \%$ & $20.0 \%$ & $8.3 \%$ \\
\hline \multirow[t]{2}{*}{ Total } & Count & 142 & 27 & 27 & 20 & 19 & 5 & 240 \\
\hline & $\begin{array}{l}\% \text { within } \\
\text { content }\end{array}$ & $100.0 \%$ & $100.0 \%$ & $100.0 \%$ & $100.0 \%$ & 100.05 & $100.0 \%$ & $100.0 \%$ \\
\hline
\end{tabular}


Table 27

Teachers' Perceptions of Questionnaire Item 34 by Content-area

\begin{tabular}{|c|c|c|c|c|c|c|c|c|}
\hline & $\begin{array}{l}\text { Content- } \\
\text { area }\end{array}$ & Elem. & Eng. & Math & Sci. & $\begin{array}{r}\text { Soc. } \\
\text { Stud. }\end{array}$ & $\begin{array}{l}\text { Comp. } \\
\text { Lit. }\end{array}$ & Total \\
\hline \multirow[t]{2}{*}{ S D } & Count & 2 & & 2 & 1 & 1 & & 6 \\
\hline & $\begin{array}{l}\% \text { within } \\
\text { content }\end{array}$ & $1.4 \%$ & & $7.4 \%$ & $5.0 \%$ & $5.3 \%$ & & $2.5 \%$ \\
\hline \multirow[t]{2}{*}{$\mathrm{D}$} & Count & 15 & 7 & 4 & 5 & 5 & 1 & 37 \\
\hline & $\begin{array}{l}\% \text { within } \\
\text { content }\end{array}$ & $10.6 \%$ & $25.9 \%$ & $14.8 \%$ & $25.0 \%$ & $26.3 \%$ & $20.0 \%$ & $15.4 \%$ \\
\hline \multirow[t]{2}{*}{$\mathrm{N}$} & Count & 31 & 4 & 6 & 5 & 2 & 1 & 49 \\
\hline & $\begin{array}{l}\% \text { within } \\
\text { content }\end{array}$ & $21.8 \%$ & $14.8 \%$ & $22.2 \%$ & $25.0 \%$ & $10.5 \%$ & $20.0 \%$ & $20.4 \%$ \\
\hline \multirow[t]{2}{*}{ A } & Count & 82 & 14 & 14 & 9 & 8 & 1 & 128 \\
\hline & $\begin{array}{l}\% \text { within } \\
\text { content }\end{array}$ & $57.7 \%$ & $51.9 \%$ & $51.9 \%$ & $45.0 \%$ & $42.1 \%$ & $20.0 \%$ & $53.3 \%$ \\
\hline \multirow[t]{2}{*}{ S A } & Count & 12 & 2 & 1 & & 3 & 2 & 20 \\
\hline & $\begin{array}{l}\% \text { within } \\
\text { content }\end{array}$ & $8.5 \%$ & $7.4 \%$ & $3.7 \%$ & & $15.8 \%$ & $40.0 \%$ & $8.3 \%$ \\
\hline \multirow[t]{2}{*}{ Total } & Count & 142 & 27 & 27 & 20 & 19 & 5 & 240 \\
\hline & $\begin{array}{l}\% \text { within } \\
\text { content }\end{array}$ & $100.0 \%$ & $100.0 \%$ & $100.0 \%$ & $100.0 \%$ & $100.0 \%$ & $100.0 \%$ & $100.0 \%$ \\
\hline
\end{tabular}


Table 28 shows the responses to item 35 (The second language instructional strategies presented through the META teacher training were useful). The majority of the responses appear clustered under the category of Agree and Strongly Agree for all content-areas. The majority of the remaining responses tend to appear under the category of Neutral for all content-areas. The results of the Chi-square test are not significant at the .05 level, $x^{2}(20, \underline{N}=240)=$ $9.67, p=.974$. Thus, there is not sufficient evidence to indicate that teachers' perceptions of the usefulness of the second language instructional strategies presented through the META teacher training are affected by the content-area in which they teach.

Table 29 shows the responses to item 36 (Participation in the META teacher training caused me to modify my approach to teaching). The majority of the responses appear distributed among Disagree, Neutral, and Agree for all content-areas except for Science, where there is an emphasis on Agree. The results of the Chi-square test are not significant at the .05 level, $x^{2}(20, \underline{N}=240)=$ $24.04, \mathrm{p}=.241$. Thus, there is not enough evidence to indicate that teachers' perceptions concerning whether participating in the META teacher training caused them to modify their approaches to teaching are dependent upon the content-area in which they teach. 
Table 28

Teachers' Perceptions of Questionnaire Item 35 by Content-area

\begin{tabular}{|c|c|c|c|c|c|c|c|c|}
\hline & $\begin{array}{l}\text { Content- } \\
\text { area }\end{array}$ & Elem. & Eng. & Math & Sci. & $\begin{array}{l}\text { Soc. } \\
\text { Stud. }\end{array}$ & $\begin{array}{l}\text { Comp. } \\
\text { Lit. }\end{array}$ & Total \\
\hline \multirow[t]{2}{*}{ SD } & Count & 4 & 1 & 2 & 1 & 1 & & 9 \\
\hline & $\begin{array}{l}\% \text { within } \\
\text { content }\end{array}$ & $2.8 \%$ & $3.7 \%$ & $7.4 \%$ & $5.0 \%$ & $5.3 \%$ & & $3.8 \%$ \\
\hline \multirow[t]{2}{*}{ D } & Count & 19 & 2 & 5 & & 2 & 1 & 29 \\
\hline & $\begin{array}{l}\% \text { within } \\
\text { content }\end{array}$ & $13.4 \%$ & $7.4 \%$ & $18.5 \%$ & & $10.5 \%$ & $20.0 \%$ & $12.1 \%$ \\
\hline \multirow[t]{2}{*}{$\mathrm{N}$} & Count & 33 & 8 & 6 & 7 & 5 & 1 & 60 \\
\hline & $\begin{array}{l}\% \text { within } \\
\text { content }\end{array}$ & $23.2 \%$ & $29.6 \%$ & $22.2 \%$ & $35.0 \%$ & $26.3 \%$ & $20.0 \%$ & $25.0 \%$ \\
\hline \multirow[t]{2}{*}{ A } & Count & 75 & 14 & 13 & 11 & 9 & 2 & 124 \\
\hline & $\begin{array}{l}\% \text { within } \\
\text { content }\end{array}$ & $52.8 \%$ & $51.9 \%$ & $48.1 \%$ & $55.0 \%$ & $47.4 \%$ & $40.0 \%$ & $51.7 \%$ \\
\hline \multirow[t]{2}{*}{$\mathrm{SA}$} & Count & 11 & 2 & 1 & 1 & 2 & 1 & 18 \\
\hline & $\begin{array}{l}\% \text { within } \\
\text { content }\end{array}$ & $7.7 \%$ & $7.4 \%$ & $3.7 \%$ & $5.0 \%$ & $10.5 \%$ & $20.0 \%$ & $7.5 \%$ \\
\hline \multirow[t]{2}{*}{ Total } & Count & 142 & 27 & 27 & 20 & 19 & 5 & 240 \\
\hline & $\begin{array}{l}\% \text { within } \\
\text { content }\end{array}$ & $100.0 \%$ & $100.0 \%$ & $100.0 \%$ & $100.0 \%$ & $100.0 \%$ & $100.0 \%$ & $100.0 \%$ \\
\hline
\end{tabular}


Table 29

Teachers' Perceptions of Questionnaire Item 36 by Content-area

\begin{tabular}{|c|c|c|c|c|c|c|c|c|}
\hline & $\begin{array}{l}\text { Content- } \\
\text { area }\end{array}$ & Elem. & Eng: & Math & Sci. & $\begin{array}{l}\text { Soc: } \\
\text { Stud. }\end{array}$ & $\begin{array}{r}\text { Comp. } \\
\text { Lit. }\end{array}$ & Total \\
\hline \multirow[t]{2}{*}{ SD } & Count & 9 & & 3 & 3 & 1 & & 16 \\
\hline & $\begin{array}{l}\% \text { within } \\
\text { content }\end{array}$ & $6.3 \%$ & & $11.1 \%$ & $15.0 \%$ & $5.3 \%$ & & $6.7 \%$ \\
\hline \multirow[t]{2}{*}{ D } & Count & 51 & 6 & 9 & 3 & 6 & 2 & 77 \\
\hline & $\begin{array}{l}\% \text { within } \\
\text { content }\end{array}$ & $35.9 \%$ & $22.2 \%$ & $33.3 \%$ & $15.0 \%$ & $31.6 \%$ & $40.0 \%$ & $32.1 \%$ \\
\hline \multirow[t]{2}{*}{$\mathrm{N}$} & Count & 35 & 8 & 5 & 1 & 5 & & 54 \\
\hline & $\begin{array}{l}\% \text { within } \\
\text { content }\end{array}$ & $24.6 \%$ & $29.6 \%$ & $18.5 \%$ & $5.0 \%$ & $26.3 \%$ & & $22.5 \%$ \\
\hline \multirow[t]{2}{*}{ A } & Count & 44 & 12 & 9 & 11 & 6 & 2 & 84 \\
\hline & $\begin{array}{l}\% \text { within } \\
\text { content }\end{array}$ & $31.0 \%$ & $44.4 \%$ & $33.3 \%$ & $55.0 \%$ & $31.6 \%$ & $40.0 \%$ & $35.0 \%$ \\
\hline \multirow[t]{2}{*}{ S A } & Count & 3 & 1 & 1 & 2 & 1 & 1 & 9 \\
\hline & $\begin{array}{l}\% \text { within } \\
\text { content }\end{array}$ & $2.1 \%$ & $3.7 \%$ & $3.7 \%$ & $10.0 \%$ & $5.3 \%$ & $20.0 \%$ & $3.8 \%$ \\
\hline \multirow[t]{2}{*}{ Total } & Count & 142 & 27 & 27 & 20 & 19 & 5 & 240 \\
\hline & $\begin{array}{l}\% \text { within } \\
\text { content }\end{array}$ & $100.0 \%$ & $100.0 \%$ & $100.0 \%$ & $100.0 \%$ & $100.0 \%$ & $100.0 \%$ & $100.0 \%$ \\
\hline
\end{tabular}


Table 30 shows the responses to item 37 (The teacher training mandated by the Consent Decree increased my professional expertise). The majority of the responses appear clustered under the category of Agree and Strongly Agree for all content-areas except for Mathematics, where they also tended to respond under the category of Disagree and Strongly Disagree. The majority of the remaining responses appear divided between the category of Disagree and Strongly Disagree and the category of Neutral for all content-areas. The results of the Chi-square test are not significant at the .05 level, $x^{2}(20, \underline{\mathrm{N}}=240)=14.27, \mathrm{p}=.816$. Thus, there is not sufficient evidence to indicate that teachers' perceptions concerning whether the teacher training mandated by the Consent Decree increased their professional expertise are affected by the content-area in which they teach.

Table 31 shows the responses for item 38 (The second language instructional strategies presented in the META teacher training were compatible with my educational philosophy). The majority of the responses appear clustered under the category of Agree and Strongly Agree for all content-areas. The majority of the remaining responses tend to be in the category of Neutral for all content-areas except Social Studies, where the emphasis is in the category of Disagree and Strongly Disagree. The significance level of the Chi-square test is .015 , indicating that the results of the Chi-square test performed on the data are significant at the .05 level, $x^{2}(20, \mathrm{~N}=240)=36.08, \mathrm{p}=.015$. Thus, there appears to be a relationship between the content-area of the teachers and their perceptions concerning whether the second language instructional strategies presented in the META teacher training were compatible with their educational philosophy. 
Table 30

Teachers' Perceptions of Questionnaire Item 37 by Content-area

\begin{tabular}{|c|c|c|c|c|c|c|c|c|}
\hline & $\begin{array}{l}\text { Content- } \\
\text { area }\end{array}$ & Elem. & Eng. & Math & Sci. & $\begin{array}{l}\text { Soc. } \\
\text { Stud. }\end{array}$ & $\begin{array}{r}\text { Comp. } \\
\text { Lit. }\end{array}$ & Total \\
\hline \multirow[t]{2}{*}{ S D } & Count & 10 & & 3 & 2 & 2 & & 17 \\
\hline & $\begin{array}{l}\% \text { within } \\
\text { content }\end{array}$ & $7.0 \%$ & & $11.1 \%$ & $10.0 \%$ & $10.5 \%$ & & $7.1 \%$ \\
\hline \multirow[t]{2}{*}{$\mathrm{D}$} & Count & 27 & 6 & 7 & 4 & 4 & 2 & 50 \\
\hline & $\begin{array}{l}\% \text { within } \\
\text { content }\end{array}$ & $19.0 \%$ & $22.2 \%$ & $25.9 \%$ & $20.0 \%$ & $21.1 \%$ & $40.0 \%$ & $20.8 \%$ \\
\hline \multirow[t]{2}{*}{$\mathrm{N}$} & Count & 41 & 8 & 8 & 2 & 5 & & 64 \\
\hline & $\begin{array}{l}\% \text { within } \\
\text { content }\end{array}$ & $28.9 \%$ & $29.6 \%$ & $29.6 \%$ & $10.0 \%$ & $26.3 \%$ & & $26.7 \%$ \\
\hline \multirow[t]{2}{*}{ A } & Count & 58 & 12 & 7 & 10 & 7 & 2 & 96 \\
\hline & $\begin{array}{l}\% \text { within } \\
\text { content }\end{array}$ & $40.8 \%$ & $44.4 \%$ & $25.9 \%$ & $50.0 \%$ & $40.0 \%$ & $40.0 \%$ & $40.0 \%$ \\
\hline \multirow[t]{2}{*}{ S A } & Count & 6 & 1 & 2 & 2 & 1 & 1 & 13 \\
\hline & $\begin{array}{l}\text { \% within } \\
\text { content }\end{array}$ & $4.2 \%$ & $3.7 \%$ & $7.4 \%$ & $10.0 \%$ & $5.3 \%$ & $20.0 \%$ & $5.4 \%$ \\
\hline \multirow[t]{2}{*}{ Total } & Count & 142 & 27 & 27 & 20 & 19 & 5 & 240 \\
\hline & $\begin{array}{l}\% \text { within } \\
\text { content }\end{array}$ & $100.0 \%$ & $100.0 \%$ & $100.0 \%$ & $100.0 \%$ & $100,0 \%$ & $100.0 \%$ & $100.0 \%$ \\
\hline
\end{tabular}


Table 31

Teachers' Perceptions of Questionnaire Item 38 by Content-area

\begin{tabular}{|c|c|c|c|c|c|c|c|c|}
\hline & $\begin{array}{l}\text { Content- } \\
\text { area }\end{array}$ & Elem. & Eng. & Math & Sci. & $\begin{array}{l}\text { Soc } \\
\text { Stud. }\end{array}$ & $\begin{array}{r}\text { Comp. } \\
\text { Lit. }\end{array}$ & Total \\
\hline \multirow[t]{2}{*}{ SD } & Count & 2 & & 1 & & 1 & & 4 \\
\hline & $\begin{array}{l}\% \text { within } \\
\text { Content }\end{array}$ & $1.4 \%$ & & $3.7 \%$ & & $5.3 \%$ & & $1.7 \%$ \\
\hline \multirow[t]{2}{*}{$\mathrm{D}$} & Count & 10 & 1 & 2 & 2 & 5 & 3 & 23 \\
\hline & $\begin{array}{l}\% \text { within } \\
\text { content }\end{array}$ & $7.0 \%$ & $3.7 \%$ & $7.4 \%$ & $10.0 \%$ & $26.3 \%$ & $60.0 \%$ & $9.6 \%$ \\
\hline \multirow[t]{2}{*}{$\mathrm{N}$} & Count & 31 & 5 & 7 & 6 & 2 & & 51 \\
\hline & $\begin{array}{l}\% \text { within } \\
\text { content }\end{array}$ & $21.8 \%$ & $18.5 \%$ & $25.9 \%$ & $30.0 \%$ & $10.5 \%$ & & $21.3 \%$ \\
\hline \multirow[t]{2}{*}{ A } & Count & 77 & 20 & 16 & 11 & 9 & 1 & 134 \\
\hline & $\begin{array}{l}5 \text { within } \\
\text { content }\end{array}$ & $54.2 \%$ & $74.1 \%$ & $59.3 \%$ & $55.0 \%$ & $47.4 \%$ & $20.0 \%$ & $55.8 \%$ \\
\hline \multirow[t]{2}{*}{ SA } & Count & 22 & 1 & 1 & 1 & 2 & 1 & 28 \\
\hline & $\begin{array}{l}\% \text { within } \\
\text { content }\end{array}$ & $15.5 \%$ & $3.7 \%$ & $3.7 \%$ & $5.0 \%$ & $10.5 \%$ & $20.0 \%$ & $11.7 \%$ \\
\hline \multirow[t]{2}{*}{ Total } & Count & 142 & 27 & 27 & 20 & 19 & 5 & 240 \\
\hline & $\begin{array}{l}\% \text { within } \\
\text { content }\end{array}$ & $100.0 \%$ & $100.0 \%$ & $100.0 \%$ & $100.0 \%$ & $100.0 \%$ & $100.0 \%$ & $100.0 \%$ \\
\hline
\end{tabular}


Table 32 shows the responses to item 39 (The META teacher training provided me with practice and feedback on my development of second language instructional strategies). The majority of the responses appear clustered under the category of Agree and Strongly Agree for all content areas. The remaining responses appear divided between the category of Disagree and Strongly Disagree and the category of Neutral. The results of the Chi-square test are not significant at the .05 level, $x^{2}(20, \underline{N}=240)=21.25, \mathrm{p}=.383$. Thus, there is not enough evidence to indicate that teachers' perceptions concerning whether the META teacher training provided them with practice and feedback on their development of second language instructional strategies are dependent upon the content-area in which they teach.

Table 33 shows the responses to item 40 (The META teacher training provided follow-up to guide me in incorporating second language instructional strategies into my particular situation). The majority of the responses appear divided between the category of Disagree and Strongly Disagree and the category of Agree and Strongly Agree for all content-areas. Elementary teachers also tended to respond in the Neutral category. The results of the Chi-square are not significant at the .05 level, $x^{2}(20, \mathrm{~N}=240)=22.81, \mathrm{p}=.298$. Thus, there is not sufficient evidence to indicate that teachers' perceptions concerning whether the META teacher training provided them with follow-up to guide them in incorporating second language instructional strategies into their particular situation are affected by the content-area in which they teach. 
Table 32

Teachers' Perceptions of Questionnaire Item 39 by Content-area

\begin{tabular}{|c|c|c|c|c|c|c|c|c|}
\hline & $\begin{array}{l}\text { Content- } \\
\text { area }\end{array}$ & Elem. & Eng. & Math & Sci. & $\begin{array}{l}\text { Soc. } \\
\text { Stud. }\end{array}$ & $\begin{array}{l}\text { Comp. } \\
\text { Lit. }\end{array}$ & Total \\
\hline \multirow[t]{2}{*}{ SD } & Count & 6 & & 4 & 1 & 1 & & 12 \\
\hline & $\begin{array}{l}\% \text { within } \\
\text { content }\end{array}$ & $4.2 \%$ & & $14.8 \%$ & $5.0 \%$ & $5.3 \%$ & & $5.0 \%$ \\
\hline \multirow[t]{2}{*}{$\mathrm{D}$} & Count & 24 & 3 & 7 & 5 & 4 & 3 & 46 \\
\hline & $\begin{array}{l}\% \text { within } \\
\text { content }\end{array}$ & $16.9 \%$ & $11.1 \%$ & $25.9 \%$ & $25.0 \%$ & $21.1 \%$ & $60.0 \%$ & $19.2 \%$ \\
\hline \multirow[t]{2}{*}{$\mathrm{N}$} & Count & 34 & 11 & 3 & 5 & 5 & & 58 \\
\hline & $\begin{array}{l}\% \text { within } \\
\text { content }\end{array}$ & $23.9 \%$ & $40.7 \%$ & $11.1 \%$ & $25.0 \%$ & $26.3 \%$ & & $24.2 \%$ \\
\hline \multirow[t]{2}{*}{ A } & Count & 73 & 12 & 12 & 8 & 8 & 2 & 115 \\
\hline & $\begin{array}{l}\% \text { within } \\
\text { content }\end{array}$ & $51.4 \%$ & $44.4 \%$ & $44.4 \%$ & $40.0 \%$ & $42.1 \%$ & $40.0 \%$ & $47.9 \%$ \\
\hline \multirow[t]{2}{*}{ S A } & Count & 5 & 1 & 1 & 1 & 1 & & 9 \\
\hline & $\begin{array}{l}\% \text { within } \\
\text { content }\end{array}$ & $3.5 \%$ & $3.7 \%$ & $3.7 \%$ & $5.0 \%$ & $5.3 \%$ & & $3.8 \%$ \\
\hline \multirow[t]{2}{*}{ Total } & Count & 142 & 27 & 27 & 20 & 19 & 5 & 240 \\
\hline & $\begin{array}{l}\% \text { within } \\
\text { content }\end{array}$ & $100.0 \%$ & $100.0 \%$ & $100.0 \%$ & $100.0 \%$ & $100.0 \%$ & $100.0 \%$ & $100.0 \%$ \\
\hline
\end{tabular}


Table 33

Teachers' Perceptions of Questionnaire Item 40 by Content-area

\begin{tabular}{|c|c|c|c|c|c|c|c|c|}
\hline & $\begin{array}{l}\text { Content- } \\
\text { area }\end{array}$ & Elem. & Eng. & Math & Sci. & $\begin{array}{l}\text { Soc. } \\
\text { Stud. }\end{array}$ & $\begin{array}{r}\text { Comp. } \\
\text { Lit. }\end{array}$ & Total \\
\hline \multirow[t]{2}{*}{ SD } & Count & 10 & 2 & 5 & 1 & 3 & 1 & 22 \\
\hline & $\begin{array}{l}\% \text { within } \\
\text { content }\end{array}$ & $7.0 \%$ & $7.4 \%$ & $18.5 \%$ & $5.0 \%$ & $15.8 \%$ & $20.0 \%$ & $9.2 \%$ \\
\hline \multirow[t]{2}{*}{$\mathrm{D}$} & Count & 38 & 8 & 12 & 7 & 6 & 3 & 74 \\
\hline & $\begin{array}{l}\% \text { within } \\
\text { content }\end{array}$ & $26.8 \%$ & $29.6 \%$ & $44.4 \%$ & $35.0 \%$ & $31.6 \%$ & $60.0 \%$ & $30.8 \%$ \\
\hline \multirow[t]{2}{*}{$\mathrm{N}$} & Count & 40 & 5 & 3 & 3 & 1 & & 52 \\
\hline & $\begin{array}{l}\% \text { within } \\
\text { content }\end{array}$ & $28.2 \%$ & $18.5 \%$ & $11.1 \%$ & $15.0 \%$ & $5.3 \%$ & & $21.7 \%$ \\
\hline \multirow[t]{2}{*}{ A } & Count & 50 & 12 & 7 & 9 & 9 & 1 & 88 \\
\hline & $\begin{array}{l}\% \text { within } \\
\text { content }\end{array}$ & $35.2 \%$ & $44.4 \%$ & $25.9 \%$ & $45.0 \%$ & $47.4 \%$ & $20.0 \%$ & $36.7 \%$ \\
\hline \multirow[t]{2}{*}{ S A } & Count & 4 & & & & & & 4 \\
\hline & $\begin{array}{l}\% \text { within } \\
\text { content }\end{array}$ & $2.8 \%$ & & & & & & $1.7 \%$ \\
\hline \multirow[t]{2}{*}{ Total } & Count & 142 & 27 & 27 & 20 & 19 & 5 & 240 \\
\hline & $\begin{array}{l}\% \text { within } \\
\text { content }\end{array}$ & $100.0 \%$ & $100.0 \%$ & $100.0 \%$ & $100.0 \%$ & $100.0 \%$ & $100.0 \%$ & $100.0 \%$ \\
\hline
\end{tabular}


Table 34 shows the responses to item 41 (Second language instructional strategies are incorporated into my daily teaching routine). The majority of the responses appear under the category of Agree and Strongly Agree for all content-areas. The majority of the remaining responses tend to be in the Neutral category for all content-areas. The significance level of the Chi-square test is .001 , indicating that the results of the Chi-square test performed on the data are significant at the .05 level, $x^{2}(20, \underline{N}=240)=46.82, p=.001$. Thus, there appears to be a relationship between the content-area of the teachers and their perceptions concerning whether second language strategies are incorporated into their daily teaching routine.

Table 35 shows the responses for item 42 (After the META teacher training I felt motivated to change my teaching style). The majority of the responses appear divided among Disagree, Neutral, and Agree for all content-areas. However, for Mathematics teachers, the emphasis is on Disagree, whereas for Science teachers, the emphasis is on Agree. The results of the Chi-square are not significant at the .05 level, $x^{2}(20, \underline{N}=240)=25.6, p=.180$. Thus, there is not enough evidence to indicate that teachers' perceptions of being motivated to change their teaching style after the META teacher training are dependent upon the content-area in which they teach. 
Table 34

Teachers' Perceptions of Questionnaire Item 41 by Content-area

\begin{tabular}{|c|c|c|c|c|c|c|c|c|}
\hline \multirow{2}{*}{$S D$} & $\begin{array}{l}\text { Content- } \\
\text { area }\end{array}$ & Elem. & Eng. & Math & Sci. & $\begin{array}{l}\text { Soc. } \\
\text { Stud. }\end{array}$ & $\begin{array}{r}\text { Comp. } \\
\text { Lit. }\end{array}$ & Total \\
\hline & Count & & & 3 & & & & 3 \\
\hline \multirow{3}{*}{$\mathrm{D}$} & $\begin{array}{l}\% \text { within } \\
\text { content }\end{array}$ & & & $11.1 \%$ & & & & $1.3 \%$ \\
\hline & Count & 4 & & 3 & 1 & 1 & 1 & 10 \\
\hline & $\begin{array}{l}\% \text { within } \\
\text { content }\end{array}$ & $2.8 \%$ & & $11.1 \%$ & $5.0 \%$ & $5.3 \%$ & $20.0 \%$ & $4.2 \%$ \\
\hline \multirow[t]{2}{*}{$N$} & Count & 18 & 4 & 9 & 3 & 4 & & 38 \\
\hline & $\begin{array}{l}\% \text { within } \\
\text { content }\end{array}$ & $12.7 \%$ & $14.8 \%$ & $33.3 \%$ & $15.0 \%$ & $21.1 \%$ & & $15.8 \%$ \\
\hline \multirow[t]{2}{*}{ A } & Count & 85 & 15 & 10 & 13 & 12 & 3 & 138 \\
\hline & $\begin{array}{l}\% \text { within } \\
\text { content }\end{array}$ & $59.9 \%$ & $55.6 \%$ & $37.0 \%$ & $65.0 \%$ & $63.2 \%$ & $60.0 \%$ & $57.5 \%$ \\
\hline \multirow[t]{2}{*}{ S A } & Count & 35 & 8 & 2 & 3 & 2 & 1 & 51 \\
\hline & $\begin{array}{l}\% \text { within } \\
\text { content }\end{array}$ & $24.6 \%$ & $29.6 \%$ & $7.4 \%$ & $15.0 \%$ & $10.5 \%$ & $20.0 \%$ & $21.3 \%$ \\
\hline \multirow[t]{2}{*}{ Total } & Count & 142 & 27 & 27 & 20 & 19 & 5 & 240 \\
\hline & $\begin{array}{l}\% \text { within } \\
\text { content }\end{array}$ & $100.0 \%$ & $100.0 \%$ & $100.0 \%$ & $100.0 \%$ & $100.0 \%$ & $100.0 \%$ & $100.0 \%$ \\
\hline
\end{tabular}


Table 35

Teachers' Perceptions of Questionnaire Item 42 by Content-area

\begin{tabular}{|c|c|c|c|c|c|c|c|c|}
\hline & $\begin{array}{l}\text { Content- } \\
\text { area }\end{array}$ & Elem. & Eng. & Math & Sci. & $\begin{array}{l}\text { Soc. } \\
\text { Stud. }\end{array}$ & $\begin{array}{l}\text { Comp. } \\
\text { Lit. }\end{array}$ & Total \\
\hline \multirow[t]{2}{*}{$S D$} & Count & 12 & 2 & 4 & 3 & 3 & & 24 \\
\hline & $\begin{array}{l}\% \text { within } \\
\text { content }\end{array}$ & $8.5 \%$ & $7.4 \%$ & $14.8 \%$ & $15.0 \%$ & $15.8 \%$ & & $10.0 \%$ \\
\hline \multirow[t]{2}{*}{$\mathrm{D}$} & Count & 48 & 6 & 11 & 3 & 6 & 3 & 77 \\
\hline & $\begin{array}{l}\% \text { within } \\
\text { content }\end{array}$ & $33.8 \%$ & $22.2 \%$ & $40.7 \%$ & $15.0 \%$ & $31.6 \%$ & $60.0 \%$ & $32.1 \%$ \\
\hline \multirow[t]{2}{*}{ N } & Count & 49 & 10 & 7 & 3 & 5 & & 74 \\
\hline & $\begin{array}{l}\% \text { within } \\
\text { content }\end{array}$ & $34.5 \%$ & $37.0 \%$ & $25.9 \%$ & $15.0 \%$ & $26.3 \%$ & & $30.8 \%$ \\
\hline \multirow[t]{2}{*}{ A } & Count & 30 & 7 & 4 & 11 & 5 & 2 & 59 \\
\hline & $\begin{array}{l}\text { \% within } \\
\text { content }\end{array}$ & $21.1 \%$ & $25.9 \%$ & $14.8 \%$ & $55.0 \%$ & $26.3 \%$ & $40.0 \%$ & $24.6 \%$ \\
\hline \multirow[t]{2}{*}{ S A } & Count & 3 & 2 & 1 & & & & 6 \\
\hline & $\begin{array}{l}\% \text { within } \\
\text { content }\end{array}$ & $2.1 \%$ & $7.4 \%$ & $3.7 \%$ & & & & $2.5 \%$ \\
\hline \multirow[t]{2}{*}{ Total } & Count & 142 & 27 & 27 & 20 & 19 & 5 & 240 \\
\hline & $\begin{array}{l}\% \text { within } \\
\text { content }\end{array}$ & $100.0 \%$ & $100.0 \%$ & $100.0 \%$ & $100.0 \%$ & $100.0 \%$ & $100.0 \%$ & $100.0 \%$ \\
\hline
\end{tabular}

Table 36 shows the responses for item 43 (The META teacher training prepared me to adapt second language instructional strategies in my classroom). The majority of the responses appear clustered under Agree for all content-areas. The remaining responses appear to be divided between the category of Disagree and Strongly Disagree and the category of Neutral for all content-areas. The 
results of the Chi-square are not significant at the .05 level, $x^{2}(20, \underline{N}=240)=$ $12.06, \mathrm{p}=.914$. Thus, there is not sufficient evidence to indicate that teachers' perceptions concerning whether the META teacher training prepared them to adapt second language instructional strategies in their classrooms are affected by the content-area in which they teach.

Table 36

Teachers' Perceptions of Questionnaire Item 43 by Content-area

\begin{tabular}{|c|c|c|c|c|c|c|c|c|}
\hline & $\begin{array}{l}\text { Content- } \\
\text { area }\end{array}$ & Elem. & Eng, & Math & Sci. & $\begin{array}{l}\text { Soc. } \\
\text { Stud. }\end{array}$ & $\begin{array}{l}\text { Comp. } \\
\text { Lit. }\end{array}$ & Total \\
\hline \multirow[t]{2}{*}{$S D$} & Count & 11 & & 3 & 2 & 2 & & 18 \\
\hline & $\begin{array}{l}\% \text { within } \\
\text { content }\end{array}$ & $7.7 \%$ & & $11.1 \%$ & $10.0 \%$ & $10.5 \%$ & & $7.5 \%$ \\
\hline \multirow[t]{2}{*}{ D } & Count & 23 & 3 & 7 & 3 & 2 & 1 & 39 \\
\hline & $\begin{array}{l}\% \text { within } \\
\text { content }\end{array}$ & $16.2 \%$ & $11.1 \%$ & $25.9 \%$ & $15.0 \%$ & $10.5 \%$ & $20.0 \%$ & $16.3 \%$ \\
\hline \multirow[t]{2}{*}{$\mathrm{N}$} & Count & 41 & 8 & 6 & 4 & 5 & & 64 \\
\hline & $\begin{array}{l}\% \text { within } \\
\text { content }\end{array}$ & $28.9 \%$ & $29.6 \%$ & $22.2 \%$ & $20.0 \%$ & $26.3 \%$ & & $26.7 \%$ \\
\hline \multirow[t]{2}{*}{ A } & Count & 60 & 14 & 11 & 10 & 9 & 4 & 108 \\
\hline & $\begin{array}{l}\% \text { within } \\
\text { Content }\end{array}$ & $42.3 \%$ & $51.9 \%$ & $40.7 \%$ & $50.0 \%$ & $47.4 \%$ & $80.0 \%$ & $45.0 \%$ \\
\hline \multirow[t]{2}{*}{ S A } & Count & 7 & 2 & & 1 & 1 & & 11 \\
\hline & $\begin{array}{l}\% \text { within } \\
\text { content }\end{array}$ & $4.9 \%$ & $7.4 \%$ & & $5.0 \%$ & $5.3 \%$ & & $4.6 \%$ \\
\hline \multirow[t]{2}{*}{ Total } & Count & 142 & 27 & 27 & 20 & 19 & 5 & 240 \\
\hline & $\begin{array}{l}\% \text { within } \\
\text { content }\end{array}$ & $100.0 \%$ & $100.0 \%$ & $100.0 \%$ & $100.0 \%$ & $100.0 \%$ & $100.0 \%$ & $100.0 \%$ \\
\hline
\end{tabular}


The following subsidiary questions were analyzed by using Multivariate Factorial Analysis of Variance computed at a significance level of .05. The data were analyzed to determine if the content-area teachers' gender, race/ethnicity, age, bilingualism, years of teaching, teaching assignment, content area, and type or year of training had an effect on their perceptions of: the mandated teacher training, the need for second language instructional strategies, and the application of these instructional strategies. P-values from the Wilk's Lambda test will be reported herein.

Subsidiary Question Four: Is there a significant difference in the content-area teachers' perceptions of the mandated teacher training depending on gender, race/ethnicity, age, or bilingualism?

Table 37 shows a significant multivariate effect for the factor race/ethnicity on the set of survey items $22,25,26,27,30,31$, and 32 when taken together, at $\mathrm{p}=.001$, thus indicating a significant difference by race/ethnicity on the teachers' perceptions of the mandated teacher training. Examining the interaction effects shows the interaction of race/ethnicity and bilingualism to be significant at the $p=.002$ level. Examination of the univariate interaction effects for race/ethnicity by bilingualism do not reveal any significant interactions. This is the result of small differences accumulating to produce a significant multivariate effect that is not found at the univariate level (Stevens, 1996). Analysis of the significant main effect of race/ethnicity reveals that race/ethnicity appears as a significant factor for all survey items except 25 (Participation in the META teacher training should be voluntary rather than mandatory). The results of the post-hoc analysis, see Table 38 , reveal that the teachers responded 
consistently in the same manner to items $22,26,27,30$, and 32 . Overall, the analysis of the data shows that together both the Black/Non-Hispanic and the Hispanic groups rate each of these items higher on the Likert scale than the White/Non-Hispanic group. There is a significant difference in the rating of each of these items among the Black/Non-Hispanic and the Hispanic groups versus the White/Non-Hispanic group. There is no significant difference in the rating of these items between the Black/Non-Hispanic and the Hispanic groups.

This pattern of response is reversed for item 31 (Prior to participation in META teacher training I thought the training had limited value). In this case, the White/Non-Hispanic group rated this item higher on the Likert scale than both the Black/Non-Hispanic and the Hispanic groups. However, there is only a significant difference in the rating of this item between the White/Non-Hispanic group versus the Black/Non-Hispanic group. There is no significant difference in the rating of this item between the Black/Non-Hispanic group and the Hispanic group. 
Table 37

Multivariate Factorial Analysis of Variance for Content-area Teachers'

Perceptions of the Mandated Teacher Training by Gender, Age, Race, and

Bilingualism

\begin{tabular}{lcccc}
\hline Factor & Wilk's' & df & Error df & Sig. \\
Gender & 0.98 & 7 & 234.000 & 0.681 \\
Age & 0.916 & 21 & 672.472 & 0.473 \\
Race & 0.857 & 14 & 468.000 & $0.001 * *$ \\
Bilingualism & 0.961 & 7 & 234.000 & 0.223 \\
Gender * Age & 0.937 & 21 & 672.472 & 0.793 \\
Gender * Race & 0.951 & 14 & 468.000 & 0.615 \\
$\begin{array}{l}\text { Gender * } \\
\text { Bilingualism }\end{array}$ & 0.965 & 7 & 234.000 & 0.294 \\
Age * Race & 0.846 & 42 & 1101.009 & 0.561 \\
Age * & 0.926 & 21 & 672.472 & 0.634 \\
Bilingualism & & 14 & 468.000 & $0.002 * *$ \\
$\begin{array}{l}\text { Race* } \\
\text { Bilingualism }\end{array}$ & 0.868 & & & \\
\hline
\end{tabular}

Note. Race $=$ race/ethnicity

$* *_{p}<.01$. 
Table 37 - Continued

Tests of between-Subjects Effects

\begin{tabular}{|c|c|c|c|c|}
\hline \multirow[t]{8}{*}{ Race } & Item & $\underline{\mathbf{F}}$ & df & Sig, \\
\hline & 22 & 6.973 & 2 & $0.001 * *$ \\
\hline & 25 & 0.983 & 2 & 0.376 \\
\hline & 26 & 4.326 & 2 & $0.014^{*}$ \\
\hline & 27 & 4.056 & 2 & $0.019^{*}$ \\
\hline & 30 & 3.610 & 2 & $0.029 *$ \\
\hline & 31 & 4.493 & 2 & $0.012^{*}$ \\
\hline & 32 & 6.787 & 2 & $0.001^{* *}$ \\
\hline \multicolumn{5}{|l|}{ Race * } \\
\hline \multirow[t]{8}{*}{ Bilingualism } & Item & F & df & Sig. \\
\hline & 22 & 2.365 & 2 & 0.096 \\
\hline & 25 & 1.694 & 2 & 0.186 \\
\hline & 26 & 2.155 & 2 & 0.118 \\
\hline & 27 & 1.387 & 2 & 0.252 \\
\hline & 30 & 1.100 & 2 & 0.335 \\
\hline & 31 & 2.937 & 2 & 0.055 \\
\hline & 32 & 2.515 & 2 & 0.083 \\
\hline
\end{tabular}

Note. ${ }^{*} \mathrm{p}<.05 *^{*} \mathrm{p}<.01$. 
Table 38

Post Hoc Analysis

\begin{tabular}{|c|c|c|c|c|c|c|}
\hline \multirow[b]{2}{*}{ Item } & \multicolumn{2}{|l|}{$\begin{array}{l}\text { Group 1/ } \\
\text { Higher }\end{array}$} & \multicolumn{4}{|l|}{$\begin{array}{l}\text { Group } 2 / \\
\text { Lower }\end{array}$} \\
\hline & Means & versus & Means & M1 & M 2 & p-value \\
\hline \multirow[t]{2}{*}{22} & Black/N-H & vs. & White/N-H & 3.74 & 2.8 & $0.0005^{* *}$ \\
\hline & Hispanic & vs. & White/N-H & 2.97 & 2.8 & $0.003 * *$ \\
\hline \multirow[t]{2}{*}{26} & Black/N-H & vs. & White/N-H & 3.80 & 3.11 & $0.001 * *$ \\
\hline & Hispanic & vs. & White/N-H & 3.35 & 3.11 & $0.015^{*}$ \\
\hline \multirow[t]{2}{*}{27} & Black/N-H & vs. & White/N-H & 3.74 & 3.03 & $0.003 * *$ \\
\hline & Hispanic & vs. & White/N-H & 3.31 & 3.03 & $0.002 * *$ \\
\hline \multirow[t]{2}{*}{30} & Black/N-H & vs. & White/N-H & 3.44 & 2.84 & $0.005 * *$ \\
\hline & Hispanic & vs. & White/N-H & 3.43 & 2.84 & $0.0005^{* *}$ \\
\hline \multirow[t]{2}{*}{31} & White/N-H & vs. & Hispanic & 3.38 & 2.81 & 0.056 \\
\hline & White/N-H & vs. & Black/N-H & 3.38 & 2.80 & $0.038^{*}$ \\
\hline \multirow[t]{2}{*}{32} & Black/N-H & vs. & White/N-H & 3.75 & 2.89 & $0.0005^{* *}$ \\
\hline & Hispanic & vS. & White/N-H & 3.05 & 2.89 & $0.001 * *$ \\
\hline
\end{tabular}

Note. Black $/ \mathrm{N}-\mathrm{H}=$ Black/Non-Hispanic; White $/ \mathrm{N}-\mathrm{H}=$ White $/$ Non-Hispanic $* \mathrm{p}<.05 * * \mathrm{p}<.01$ 
Subsidiary Question Five: Is there a significant difference in the content-area teachers' perceptions of the need for second language instructional strategies depending on their years of teaching, teaching assignment, and content-area?

Table 39 shows that the results of the Multivariate Factorial Analysis of Variance are not significant at the .05 level, indicating that the teachers' years of teaching, teaching assignment (Asignmen), and content-area did not have a significant effect on the teachers' perceptions of the need for second language instructional strategies.

Table 39

Multivariate Factorial Analysis of Variance for Content-area Teachers' Perceptions of the Need for Second Language Instructional Strategies by Years of Teaching, Teaching_Assignment (Asignmen), and Content-area

\begin{tabular}{lcccc}
\hline Factor & Wilk's & df & Error df & Sig. \\
Years & 0.949 & 12 & 386.000 & 0.591 \\
Asignmen & 0.904 & 18 & 546.372 & 0.349 \\
Content & 0.825 & 30 & 774.000 & 0.155 \\
$\begin{array}{l}\text { Years * } \\
\text { Asignmen }\end{array}$ & 0.831 & 36 & 850.283 & 0.445 \\
Years * & 0.784 & 54 & 988.705 & 0.693 \\
$\begin{array}{l}\text { Asignmen * } \\
\text { Content }\end{array}$ & 0.715 & 54 & 988.705 & 0.116 \\
\hline
\end{tabular}


Subsidiary Question Six: Is there a significant difference in the content-area teachers' perceptions concerning the application of second language strategies depending on their years of teaching, teaching assignment, and content-area?

Table 40 shows that the results of the Multivariate Factorial Analysis of Variance are not significant at the .05 level, indicating that the teachers' years of teaching, teaching assignment, and content-area did not have a significant effect on their perceptions concerning the application of second language strategies.

Table 40

Multivariate Factorial Analysis of Variance for Content-area Teachers'

Perceptions Concerning the Application of Second Language Instructional

Strategies by Years of Teaching. Teaching Assignment (Asignmen), and

Content-area

\begin{tabular}{lcccc}
\hline Factor & Wilk's & df & Error df & Sig. \\
Years & 0.973 & 8 & 390.000 & 0.727 \\
Asignmen & 0.962 & 12 & 516.213 & 0.807 \\
Content & 0.906 & 20 & 647.692 & 0.485 \\
$\begin{array}{l}\text { Years * } \\
\text { Asignmen }\end{array}$ & 0.927 & 24 & 681.484 & 0.917 \\
$\begin{array}{l}\text { Years * } \\
\text { Asignmen * }\end{array}$ & 0.850 & 36 & 732.493 & 0.631 \\
Content & 0.828 & 36 & 732.493 & 0.389 \\
\hline
\end{tabular}


Subsidiary Question Seven: Is there a significant difference in the content-area teachers' perceptions of the mandated teacher training depending on how they were trained and when they were trained?

Table 41 shows that the results of the Multivariate Factorial Analysis of Variance are not significant at the .05 level, indicating that how they were trained (Complian) and when they were trained (YrTrain) did not have a significant effect on their perceptions of the mandated teacher training.

Table 41

Multivariate Factorial Analysis of Variance for Content-area Teachers'

Perceptions of the Mandated Teacher Training by How They Were Trained (Complian) and When They Were Trained (YrTrain)

\begin{tabular}{|c|c|c|c|c|}
\hline Factor & Wilk's & df & Error df & Sig. \\
\hline Complian & 0.966 & 4 & 175.000 & 0.192 \\
\hline YrTrain & 0.846 & 32 & 646.963 & 0.568 \\
\hline $\begin{array}{l}\text { Complian * } \\
\text { YrTrain }\end{array}$ & 0.883 & 28 & 632.394 & 0.766 \\
\hline
\end{tabular}


Subsidiary Question Eight: Is there a significant difference in the content-area teachers' perceptions of the need for second language instructional strategies depending on how they were trained and when they were trained?

Table 42 reveals that a significant multivariate difference exists between the teachers based on when they were trained (YrTrain), Wilk's $=.680, \mathrm{df}=48$; $855.3, \mathrm{p}=.026$, thus indicating a difference by the year they were trained on their perceptions of the need for second language instructional strategies. However, examination of the univariate interaction effects for when they were trained (YrTrain), does not reveal any significant interaction. Thus, while significant multivariate differences exist, the univariate results are not significant. Again, this is the result of small differences accumulating to produce a significant multivariate effect that is not found at the univariate level (Stevens, 1996).

Table 42

Multivariate Factorial Analysis of Variance for Content-area Teachers'

Perceptions of the Need for Second Language Instructional strategies by How They Were Trained (Complian) and When They Were Trained (YrTrain)

\begin{tabular}{lcccr}
\hline Factor & Wilk's & df & Error df & Sig. \\
Complian & 0.951 & 6 & 173.000 & 0.181 \\
YrTrain & 0.680 & 48 & 855.295 & $0.026^{*}$ \\
$\begin{array}{l}\text { Complian * } \\
\text { YrTrain }\end{array}$ & 0.869 & 42 & 814.894 & 0.982 \\
\hline
\end{tabular}


Table 42 - Continued

Tests of between-Subjects Effects

\begin{tabular}{ccccc}
\hline YrTrain & Item & F & df & Sig. \\
13 & 1.726 & 8 & 0.095 \\
14 & 1.490 & 8 & 0.164 \\
15 & 1.027 & 8 & 0.417 \\
16 & 1.037 & 8 & 0.410 \\
17 & 1.924 & 8 & 0.059 \\
18 & 1.388 & 8 & 0.205
\end{tabular}

Note. ${ }^{*} p<.05$

Subsidiary Question Nine: Is there a significant difference in the content-area teachers' perceptions concerning the application of second language instructional strategies depending on how they were trained and when they were trained?

Table 43 shows that the results of the Multivariate Factorial Analysis of Variance are not significant at the .05 level, indicating that how they were trained (Complian) and when they were trained (YrTrain) did not have a significant effect on their perceptions concerning the application of second language instructional strategies. 
Table 43

Multivariate Factorial Analysis of Variance for Content-area Teachers'

Perceptions Concerning the Application of Second Language Instructional

strategies by How They Were Trained (Complian) and When They Were Trained (YrTrain)

\begin{tabular}{lcccc}
\hline Factor & Wilk's & df & Error df & Sig. \\
Complian & 0.948 & 6 & 173.000 & 0.156 \\
YrTrain & 0.756 & 48 & 855.295 & 0.399 \\
$\begin{array}{l}\text { Complian * } \\
\text { YrTrain }\end{array}$ & 0.769 & 42 & 814.894 & 0.282 \\
\hline
\end{tabular}

\section{SUMMARY}

The purpose of this study was to explore the content-area teachers' perceptions of the effect that compliance with the mandated training for content-area teachers of LEP students has had on their instructional practices within the classroom. For the purpose, it was decided to survey content-area teachers who had completed the mandatory training in order to gather data which would reflect their perspectives on the issues under study. To this end, the teachers responded to thirty-two items on a forty-three item survey using a five-point Likert scale. The first eleven items gathered demographic data. The thirty-two items were grouped according to one of the first three subsidiary questions of the research study. 
Statistical analyses were performed to determine if a relationship existed between the perceptions of the content-area teachers and the need for second language instructional strategies, the mandated teacher training requirement, and the implementation of second language instructional strategies within the content-area classroom. In order to assess these relationships, the data were analyzed using measures of central tendency, cross-classification analysis, and Chi-square. A series of tables was included to present the statistical results of the analysis of each of the survey items.

In general, the measures of central tendency indicated that the majority of the responses had a tendency to range between Neutral and Agree for all content-areas. The only exceptions to this tendency were found in the responses to item 28, which ranged closer to Neutral than to Agree, and in the responses to items $12,21,40$, and 42 , which had a tendency to range between Disagree and Neutral. Cross-classification analysis and Chi-square results indicated a relationship between the content-area of the teachers and their perceptions of the need for second language instructional strategies only in the responses to items 13,15 , and 21 . The only indication of a relationship between the content-area of the teachers and their perceptions of the mandated teacher training was found in the responses to item 30 . Indication of a relationship between the content-area of the teachers and their perceptions concerning the implementation of second language instructional strategies within the content-area classroom were only found in the responses to items 33,38 , and 41 . In the majority, the teachers responses to the thirty-two items fell under the category of Agree. Only the responses to items $12,28,31,36$, and 42 appeared divided between Disagree, 
Neutral, and Agree, and the responses to items 21 and 40 appeared under the category of Disagree and Strongly Disagree.

Statistical analyses were also performed to determine if there were significant differences in the teachers' perceptions of the mandated teacher training, the need for second language instructional strategies, and the application of these instructional strategies depending on their gender, race/ethnicity, age, bilingualism, years of teaching, teaching assignment, content-area, and type or year of training. In order to assess the significant differences, the data was analyzed using Multivariate Factorial Analysis of Variance. Univariate tests focused on particular factors which produced the overall significant differences. A series of tables was created to present the statistical results. In general, the teachers' perceptions were not affected by these factors. There only appeared to be a significant difference by race/ethnicity on the teachers' perceptions of the mandated teacher training at both the multivariate and univariate level. The post-hoc analysis revealed that there was a significant difference in how the Black/Non-Hispanic and the Hispanic groups rated the items versus the White/Non-Hispanic group. The interaction of race/ethnicity by bilingualism appeared significant at the multivariate level but not at the univariate level. The year they were trained appeared to have a significant effect on their perceptions of the need for second language instructional strategies only at the multivariate level. Examination of the univariate interaction effects did not reveal any significant interaction. 
CHAPTER FIVE

\section{SUMMARY OF THE STUDY}

This study investigated the content-area teachers' perceptions of the effect that the teacher training mandated by the Consent Decree has had on their instructional practices. The Consent Decree focused on the rights of the Limited English Proficient (LEP) student to be provided, by a trained educator, with academic instruction in English that is understandable to them. This stipulation required that all educators who come into contact with LEP students be trained in the use of techniques, methods, and strategies to be used with students who lack proficiency in English in order to provide these students with academic instruction that they could comprehend. There was concern on the part of the researcher, based on the review of literature, that training requirements mandated through legislation might be considered by the teachers to be an unwarranted imposition and thus affect these teachers' perceptions of the benefits of the training and their implementation of the strategies. "Even teachers who may be supportive of state-mandated changes, or at least not resistant to them, do not necessarily implement them in their classroom as planned" (Klein, 1991b, p. 222). There was also concern that the teacher training provided might not be sufficient to cause teachers to implement the new strategies because transferring a new skill into active use would signify change and change, at times, is not easily accomplished. According to Chin and Benne (1985), there is some resistance to change. "Frequently, people have learned to defend against the potential lessons of experience when these threaten existing equilibrium, whether in the person or in the social system" (Chin and Benne, 1985, p. 36). 
However, the ever-increasing population of language minority students in the classroom indicates the need for teachers to redefine their approach in working in a multilingual setting. "Whatever the future holds, all teachers will require continuing professional education in order to adjust to new tasks and demands" (Kyriacou, 1996, p. 11). Content-area teachers are exposed to instructional strategies and methods that facilitate learning for language minority students through the mandatory training; nevertheless, concern remains as to whether this training is perceived to have an impact on instructional practices in the classroom.

This study was conceptualized when the researcher participated as a teacher trainer and was intrigued by the comments of some of the participants concerning the fact that the training was mandatory. Consequently, the researcher decided to investigate the content-area teachers' perceptions of the effect of the training mandated by the Consent Decree. To this end, it was decided to survey content-area teachers who had completed the mandatory training using a researcher-developed instrument. The instrument consisted of two sections. The first section requested demographic information. The second contained thirty-two statements which surveyed the content-area teachers' perceptions concerning the Consent Decree, teacher training, the need for second language strategies, and the application of these strategies. These thirty-two statements were grouped according to one of the first three subsidiary questions. The teachers responded to the survey items using a five-point Likert scale ranging from "one" for Strongly Disagree to "five" for Strongly Agree. A stratified sample of 400 was selected from the population of all currently employed 
elementary, middle, and high school content-area teachers who had taken the mandatory training. Out of the 400 questionnaires mailed out to the school site, 274 , or $69 \%$, were returned. Statistical analyses were performed to determine if a reliable relationship existed between the perceptions of the content-area teachers and the need for second language instructional strategies, the mandated teacher training requirement, and the implementation of second language instructional strategies within the classroom. Statistical analyses were also performed to determine if there were significant differences in these perceptions based on gender, race/ethnicity, bilingualism, years of teaching, teaching assignment, content-area, and type or year of training. For discussion purposes, the results from the aforementioned analyses will be used to draw conclusions and answers to the subsidiary questions.

\section{FINDINGS}

Subsidiary Question One: What are the content-area teachers' perceptions concerning the LEP students' need of second language instructional strategies within the content-area classroom?

Items 12 through 21 of the instrument relate to this research question. The data indicated that the majority of the teachers' responses to items 12 through 21 had a tendency to range between Neutral and Agree for all content-areas. These results indicated that in the majority the teachers surveyed either agreed that the LEP students needed second language instructional strategies within the content-area classroom or they had no opinion on the matter. The only exceptions to this tendency were found in the responses to item 12 and item 21 . 
For these two items, the responses appeared to range between Disagree and Neutral.

The tendency for responses to range closer to Disagree when responding to item 12 (The Consent Decree provides Limited English Proficient (LEP) students with more educational rights than other students have) indicated that the majority of the teachers surveyed did not feel that the Consent Decree provides LEP students with more educational rights than other students even though this appeared to be a concern for the State of Florida when it felt obligated to clarify in a memorandum that "The Consent Decree has not created new rights for LEP students" (B. A. Garcia, personal communication, June 27, 1995). This may be an indication that the training was successful in clarifying for the teachers the intent of the Consent Decree.

The tendency for responses to range closer to Disagree when responding to item 21 (Teaching the LEP student should be the responsibility only of the teachers in the Bilingual Program) indicated that the majority of the teachers surveyed did not believe the teaching of the LEP student should only be done by the bilingual department teachers even though the review of literature indicated that the assumption exists that the academic training of language minority students is the responsibility of specialized bilingual personnel and not the mainstream teacher. This may indicate that the training was successful in helping the teachers to realize, as stated in the review of literature, that the ever-increasing population of language minority students indicates the need for teachers to redefine their approach in working in a multilingual setting. Nonetheless, there was a significant relationship between the content-area of the 
teachers and their responses to this item. Mathematics teachers showed a tendency to respond in the category of Agree and Strongly Agree for this item, indicating that there was a group of these content-area teachers who appeared to feel that teaching the LEP student should be the sole responsibility of the bilingual department teachers, perhaps indicating a concern over their ability to impart complicated mathematical concepts and terminology to LEP students without the benefit of the native language.

Cross-classification and Chi-square results indicated that there was a significant relationship between the content-area of the teachers and their perceptions of the need for second language instructional strategies only in the responses to items 13,15 , and 21 . Items 13 and 15 can be looked at together since their premise is similar. Item 21 was presented and discussed in the previous paragraph. Although the majority of the responses to both of these items appeared clustered under the category of Strongly Agree and Agree for all content-areas, Mathematics teachers were again an exception. On item 13 (Second language instructional strategies geared to the LEP students facilitate their ability to comprehend the content-area lesson better), they appeared divided between Neutral or Agree and on item 15 (Second language instructional strategies geared towards the LEP students allow them to experience greater academic success in the content-areas), they tended to respond in the Neutral category. These results appeared to indicate that the perceptions of the Mathematics teachers concerning the need for second language instructional strategies differ significantly from the perceptions of the other content-area teachers. Whereas the other content-area teachers appeared to agree with the 
premise set forth in the review of literature, that second language strategies are beneficial to the LEP student, it seemed as if some of the Mathematics teachers did not perceive second language strategies as facilitating the LEP students comprehension of the content-area lesson better. This difference may be due to the view that some teachers hold concerning mathematics as a set body of knowledge that can be learned by carefully following the teachers' demonstrations and explanations (Prawat, 1992).

Subsidiary Question Two: What are the content-area teachers' perceptions concerning the teacher training mandated in the Consent Decree?

Items 22 through 30 of the instrument relate to this research question. The measures of central tendency indicated that the majority of the teachers' responses to items 22 through 30 had a tendency to range between Neutral and Agree for all content-areas. These results indicated that in the majority the teachers surveyed either agreed with the teacher training mandated in the Consent Decree or had no opinion on the matter. The only exception to this tendency was found on item 28. For this item the responses tended to range closer to Neutral than to Agree.

At this point, it seems necessary to focus on one item whose premise differs from the others in this section. Item 25 stated that participation in the META teacher training should be voluntary rather than mandatory. The majority of the teachers tended to respond in the category of Agree and Strongly Agree (47.9\%), indicating that they felt the mandated training was an imposition, although there was also an emphasis on the category of Disagree and Strongly Disagree $(37.9 \%)$, indicating that a group of content-area teachers felt that the 
teacher training should be mandated. Nevertheless, the difference was not significant.

The responses to item 28 (The teacher training mandated by the Consent Decree took the teachers perspectives into consideration in its development) appeared divided among Disagree, Neutral, and Agree for all content-areas, with the remaining responses tending to be grouped under Strongly Disagree. These results indicated that a majority of the teachers surveyed felt that the teacher training did not take the teachers' perspectives into consideration in its development. The review of literature indicated that involvement of the teacher in the process of professional development is a factor which might have an effect on the implementation of mandated training (Christensen \& Burke, 1982; Fullan, 1993; Holly, 1982; Lieberman \& Miller, 1981; Mohlman et al., 1982; Wood et al., 1982. However, there was also a group of teachers who had no opinion on the matter and a group who felt that the teachers' perspectives had been taken into account. Therefore, the results appear inconclusive as there was not an overwhelming majority who felt that the teachers' perspectives had not been taken into account in the development of the teacher training.

Cross-classification and Chi-square results indicated that there was a significant relationship between the content-area of the teachers and their perceptions concerning the teacher training mandated in the Consent Decree only in the responses to item 30. Item 30 stated that the Consent Decree was a necessary piece of legislation. The majority of the responses appeared clustered under Agree for all content-areas except for Elementary, where there was a slight emphasis on Neutral indicating that these teachers' opinions on this matter were 
not as strong as that of the other teachers. These results indicated that the majority of the teachers appeared to agree that the Consent Decree was a necessary piece of legislation, although there may be a relationship between the content-area of the teachers and their perceptions on this matter. The results appeared to favor, even though there was not an overwhelming majority of support, the premise set forth in the review of literature that continuing litigation has been necessary to enforce, expand, and clarify the rights of language minority students initially established in 1968 through the Bilingual Education Act.

Subsidiary Question Three: What changes are perceived to have occurred in the content-area teachers' instructional practices as a result of the training?

Items 31 through 43 of the instrument relate to this research question. The measures of central tendency indicated that the majority of the teachers' responses to items 31 through 43 had a tendency to range between Neutral and Agree for all content-areas. These results indicated that the majority of teachers surveyed either agreed that changes had occurred in their instructional practices as a result of the training or they had no opinion on the matter. The only exceptions to this tendency were found in the responses to item 40 and item 42 For these two items the majority of the responses appeared to range between Disagree and Neutral.

The responses to item 40 (The META teacher training provided for follow-up to guide me in incorporating second language instructional strategies into my particular situation) appeared divided relatively evenly between the category of Disagree and Strongly Disagree and the category of Agree and 
Strongly Agree for all content-areas with the remaining responses falling under the Neutral category. These results indicated that the teachers appeared divided in their opinions concerning whether the teacher training provided them with follow-up to guide them in incorporating second language instructional strategies into their particular situation. A group of respondents appeared to have no opinion on the matter. Therefore, results appear inconclusive in substantiating or refuting the premise set forth in the review of literature which indicated that staff development should provide follow-up or coaching where the teachers are helped to incorporate the new teaching approach into their repertoire of skills within their individual teaching situations (Fullan, 1992; Microsoft, 1998; "The Policy Dilemma", 1994).

The majority of the responses to item 42 (After the META teacher training I felt motivated to change my teaching style) appear divided among Disagree, Neutral, and Agree with a slight emphasis on Disagree. The tendency for responses to range closer to Disagree when responding to item 42 indicated that a slight majority of the teachers surveyed did not feel motivated to change their teaching style after the META training. This may be due to the premise stated in the review of literature that there must be an awareness of the need to change, a clear and specific understanding of the innovation and what it can accomplish, which would make the effort of implementing it worthwhile and also a blending of the new practice with the teachers' current mode of presentation (Fullan, 1992; Fullan, 1993; Joyce et al. 1987; Leiberman \& Miller, 1981; Mohlman et al. 1982; Sparks, 1983). These results would appear to concur in part with the premise set forth in the review of literature that simply providing information and reasons for 
a change does not signify that a change will take place if the person is not involved in the change process. Change is a process and initially there is resistance to change (Chin \& Benne, 1985). Nevertheless, it should be kept in mind that this was not a clear majority. Some teachers perceived that they did feel motivated to change their teaching style after the training, which can be taken as an indication of their involvement in a change process. These results would appear to concur with another premise set forth in the review of literature that "the opportunity to take on new roles and tasks, and to develop new approaches to their work, offers teachers, at various points in their career, welcome challenges that help to prevent a sense of stagnation occurring" (Kyriacou, 1996, p. 9). In addition, one must also indicate that there was also a group who had no opinion on the matter.

Cross-classification and Chi-square results indicated that there was a significant relationship between the content-area of the teachers and the changes they perceived to have occurred in their instructional practices as a result of the training only in the responses to items 33,38 , and 41 .

For item 33 (After the META teacher training I feel competent using second language instructional strategies in the content-area classroom) the majority of the responses appear clustered under the category of Agree and Strongly Agree for all content-areas. The majority of the remaining responses tend to be clustered under Neutral except for Social Studies and Computer Literacy teachers, where the emphasis is on Disagree. The results indicated that the majority of the teachers appeared to agree that after the META training they felt competent in using second language strategies in the classroom. Nevertheless, 
there may be a relationship between the content-area of the teachers and their perceptions on this matter. It appears that some of the Social Studies and Computer Literacy teachers did not feel competent in using second language instructional strategies after the training. For Social Studies teachers, this may be due to the fact that "social studies demands a high level of literacy skills and often relies heavily on the textbook ... and they [the teachers] require support in learning strategies for developing students' academic literacy (Short, 1998, pp. VI-3-VI-10). For Computer Literacy teachers, this may be due to the fact that they, "must develop methods for teaching necessary skills to students who do not respond well to traditional methods of teaching" (Wright \& Fair, 1992, p. 246). Nonetheless, these results appear to indicate that, in the majority, the teachers found the inservice to be of value as it is described in the review of literature "that if inservice training is to have real value, it must prepare teachers to apply new methods and techniques..., adapt and utilize new concepts in the classroom (Ambert \& Melendez, 1985, p. 283), even though it was not an overwhelming majority who agreed.

For item 38 (The second language instructional strategies presented in the META teacher training were compatible with my educational philosophy) the majority of the responses appear clustered under the category of Agree and Strongly Agree for all content-areas. The majority of the remaining responses tend to be in the category of Neutral for all content-areas except Social Studies, where the emphasis is on Disagree. The results indicated that the majority of the teachers appeared to agree that the instructional strategies presented through the META teacher training were compatible with their educational philosophy. 
Nevertheless, there may be a relationship between the content-area of the teachers and their perceptions on this matter. It appears that some of the Social Studies teachers did not feel the instructional strategies presented were compatible with their educational philosophy. This may be due to the fact that, "most of the content standards . . . including those written for . . social studies, were developed for monolingual English-speaking students, primarily by teachers, researchers, and policymakers who did not have expertise in the process of learning content through a second language" (Short, 1998, p. VI-4). The review of literature indicated that compatibility of the recommendations to teachers' educational philosophy is a factor which might have an effect on the implementation of the mandated training (Christensen \& Burke, 1982; Fullan, 1993; Holly, 1982; Leiberman \& Miller, 1981; Mohlman et al., 1982; Wood et al., 1982). Nevertheless, from the results, it appears as if a majority of the teachers perceive that they implement the strategies since they felt that these were compatible with their educational philosophy.

For item 41 (Second language instructional strategies are incorporated into my daily teaching routine) a clear majority of the responses appear under the category of Agree and Strongly Agree for all content-areas. The majority of the remaining responses tend to be in the Neutral category for all content-areas, with a greater percentage of Mathematics and Social Studies teachers responding in this category than those who responded in the category of Strongly Agree. The results generally indicated the teachers perceive that second language strategies are incorporated into their daily teaching routine. Nevertheless, there may be a relationship between the content-area of the teachers and their perceptions on this 
matter. It appears Mathematics and Social Studies teachers were not in as much agreement with other content-area teachers, that second language instructional strategies are incorporated into the daily teaching routine. This may be due to aspects in these two areas which have been presented and discussed previously. These results appear not to concur with the premise set forth in the review of literature that "the development of skill by itself does not ensure transfer; relatively few teachers, having obtained skill in a new approach, will then transfer that skill into their active repertoire and use the new approach regularly" (Joyce \& Showers, 1982, p. 5).

Subsidiary Question Four: Is there a significant difference in the content-area teachers' perceptions of the mandated training depending on gender, race/ethnicity, age, or bilingualism?

Race/ethnicity was the only factor on which there was a significant effect on the teachers' perceptions of the mandated training at both the multivariate and the univariate level. Race/ethnicity appeared as a significant factor for items 22 , $26,27,30,31$, and 33. These results indicated that the teachers' perceptions of the mandated training were affected by their race/ethnicity. The results of the post-hoc analysis revealed that the teachers' pattern of responses was the same for items 22, 26, 27, 30, and 32. The Black/Non-Hispanic and the Hispanic groups together rated each of these items higher on the Likert scale than did the White/Non-Hispanic group. This pattern of response was reversed for item 31 (Prior to participation in META teacher training, I thought the training had limited value). In this case, the White/Non-Hispanic group rated this item higher on the Likert scale than both the Black/Non-Hispanic and the Hispanic groups 
combined. These results indicated that the attitudes of both the Black/Non-Hispanic and the Hispanic groups appeared to be more positive towards the mandated teacher training than those of the White/Non-Hispanic group. This pattern of responses may reflect a premise set forth in the review of literature which indicated that at times minorities have felt that legislation is necessary in order for them to be afforded equal educational opportunities on a par with the mainstream group. According to Ambert \& Melendez (1985), "before the 1960 's, it was assumed that uniform educational treatment was beneficial to all children" (p. 27). The idea of conforming to the mainstream, dominant cultural view remained the mainstay of the social institutions until the era of the Civil Rights movement in the 1960's. According to Appleton (1983), Gollnick and Chinn (1986), McCarthy (1990), Phillips (1988), Reagan (1985), and Suzuki (1984), social upheaval occurred in the 1960's when minority groups reacted, at times violently, to what they felt was a system which promoted social inequality, discrimination, segregation, and a lack of equal educational opportunities for minorities. As a result of these social upheavals, there occurred an awareness of and an outcry against the cultural bias which was felt to exist in the schools. Thus, demands were advanced for ethnic studies, cultural awareness programs, educational reforms, and minority representation.

Race/ethnicity was not a significant factor in the responses to item 25 , which stated that participation in the META teacher training should be voluntary rather than mandatory. In this case, the results indicated that the teachers' perceptions concerning voluntary training versus mandatory training were not affected by their race/ethnicity. 
Subsidiary Question Five: Is there a significant difference in the content-area teachers' perceptions of the need for second language instructional strategies depending on their years of teaching, teaching assignment, and content-area?

The results of the Multivariate Factorial Analysis of Variance were not significant, indicating that the teachers' years of teaching, teaching assignment, and content-area did not have a significant effect on the teachers' perceptions of the need for second language instructional strategies. These results indicated that, in general, the teachers' perceptions of the LEP students' need for second language instructional strategies within the content-area were not affected by the aforementioned factors.

Subsidiary Question Six: Is there a significant difference in the content-area teachers' perceptions concerning the application of second language strategies depending on their years of teaching, teaching assignment, and content-area?

The results of the Multivariate Factorial Analysis of Variance were not significant, indicating that the teachers' years of teaching, teaching assignment, and content-area did not have a significant effect on the teachers' perceptions concerning the application of second language strategies. These results indicated that, in general, the teachers' perceptions concerning the need for implementing second language instructional strategies within the content-area classroom were not affected by the aforementioned factors. 
Subsidiary Question Seven: Is there a significant difference in the content-area teachers' perceptions of the mandated teacher training depending on how they were trained and when they were trained?

The results of the Multivariate Factorial Analysis of Variance were not significant indicating that how they were trained and when they were trained did not have a significant effect on their perceptions of the mandated teacher training. These results indicated that, in general, the teachers' perceptions of the mandated teacher training were not affected by the type of training they received, which was either through a teacher inservice course or through a university course, or by the year in which they were trained.

Subsidiary Question Eight: Is there a significant difference in the content-area teachers' perceptions of the need for second language instructional strategies depending on how they were trained and when they were trained?

When teachers were trained appears to have a significant effect on the teachers' perceptions of the need for second language instructional strategies at the multivariate level; however, the interaction effects at the univariate level were not significant. These results indicated that the teachers' perceptions of the LEP students' need for second language instructional strategies within the content-area classroom ultimately were not affected by the year in which they were trained.

Subsidiary Question Nine: Is there a significant difference in the content-area teachers' perceptions concerning the application of second language instructional strategies depending on how they were trained and when they were trained? 
The results of the Multivariate Factorial Analysis of Variance were not significant, indicating that how and when teachers were trained did not have a significant effect on their perceptions concerning the application of second language instructional strategies. The results indicated that, in general, the teachers' perceptions concerning the need for implementing second language strategies within the content-area classroom were not affected by the type of training they received, which was either through a teacher inservice course or through a university course, or by the year in which they were trained.

\section{SUMMARY OF THE FINDINGS}

Overall, the majority of the teachers' responses to the thirty-two items on the survey had a tendency to range between Neutral and Agree for all content-areas. Recalling the comments expressed by some of the teachers concerning the mandatory teacher training and the discussion in the review of literature where it was indicated that legislatively mandated teacher training requirements may be perceived by some teachers as an unwarranted imposition and thus affect their perceptions regarding the training, it was thought that these feelings would be reflected to a greater degree in the responses to the survey. However, as indicated by the large percentage of responses which ranged from Neutral to Agree, it is to be concluded that the teachers were, in general, either in agreement with the mandated training and the need for second language strategies and implementation of these strategies or were for some reason hesitant to make a definitive statement. The latter assumption may be based on the tendency of some respondents to answer as they believed was expected of them and not as they truly felt even though the survey was anonymous. This conclusion does not 
appear to concur with the discussion in the review of literature concerning the imposition of training and how it can negatively affect teachers' views of the training and the need for new strategies and implementation of these strategies nor does it concur with what was observed when the researcher participated as a teacher trainer in the META teacher training. However, it does appear to concur with the discussion in the review of literature indicating that although there is initially resistance to change, change is possible if the teachers have begun to be involved in a change process.

As a consequence of these results, it appears from the teachers' responses that the training is acceptable in the way it is being offered and it is being successful in training the teachers to implement second language strategies within their content-area classrooms. It appears that the mandatory nature of the training initially may have had a negative effect on some of the teachers' views, as was observed when these teachers attended the training offered by the researcher. However, it did not appear to have a negative effect on their views of the training and the strategies to be implemented once the training was completed. One must conclude that even though it is stated that "professionally-oriented teachers oppose external mandates pertaining to classroom functions, for their culture holds that they are the educational experts" (Schwartz, 1991, p. 79); nevertheless, "for many teachers, the opportunity to develop new skills provides them with a chance to rejuvenate their teaching careers" (Kyriacou, 1996, p. 9). In addition, there may be another factor which may have had an effect on the results of this study as opposed to the results of other studies discussed in the review of literature. This factor is the setting where the study was conducted. Miami-Dade 
County's racial/ethnic background may be considered unique. According to Boswell (1998), "61\% of the state's Hispanics lived in Miami-Dade County in 1990. The Miami-Dade Planning Department projects that by 2015 the county's population will be $67 \%$ Hispanic, $19 \%$ Black and only $14 \%$ Anglo" (p. I-4). It is possible that a study conducted where there is a population with a greater concentration of minorities may have different results than studies conducted elsewhere. A greater concentration of minority respondents may view issues of mandated training and the need for and implementation of instructional strategies in a more positive light since they are minorities themselves.

The findings of the study may suggest this effect when it was shown that, generally speaking, the teachers' gender, age, bilingualism, years of teaching, teaching assignment, and type or year of training did not have a significant effect on their perceptions of the mandated teacher training, the need for second language instructional strategies, and the application of these strategies within the content-area classroom. The only factor which appeared to have a significant effect on their perceptions of the mandated teacher training was race/ethnicity. The Black/ Non-Hispanic and the Hispanic groups did not have a significant difference between them; however, there was a significant difference between both of these two groups and the White/Non-Hispanic group. Both the Black/Non-Hispanic and the Hispanic groups appeared to rate the responses higher on the Likert scale than the White/Non-Hispanic group, indicating a higher level of agreement with the mandated teacher training. As was stated previously, this pattern of responses appeared to correlate with the discussion presented in the review of literature which indicated that at times minorities have felt that 
legislative actions have been necessary in order to clarify their rights and provide them with equal educational opportunities within the educational system. At this point, it seems pertinent to examine the distribution of the racial/ethnic background of the respondents to the questionnaire. Out of the 274 respondents, 108 , or $39.4 \%$, were White/Non-Hispanic; 102 , or $37.2 \%$, were Hispanic; 58 , or $21.2 \%$, were Black/Non-Hispanic. Six of the respondents, or $2.2 \%$, did not indicate their racial/ethnic background. See Table 44.

Table 44

Distribution of the Racial/Ethnic Background of Respondents to the Questionnaire

Race/Ethnicity

White/Non-Hispanic

Hispanic

Black/Non-Hispanic

Not Provided

Total

\section{Total}

108

102

58

6

274
Percent

$39.4 \%$

$37.2 \%$

$21.2 \%$

$2.2 \%$

$100.0 \%$

As can be seen, there was a greater percentage of Hispanic and Black/Non-Hispanic respondents taken together than White/Non-Hispanic respondents, indicating a greater minority concentration.

Since the teachers were in agreement with the training as it is being offered and it appears to be successful in training the teachers to implement second language strategies, focusing attention on the few individual items where 
there was some deviation from the general pattern of responses may provide some basis for formulating implications for teacher training. Responses to items 28 , 36, and 42 appeared divided among Disagree, Neutral, and Agree rather than just ranging from Neutral to Agree. The responses to item 40 appeared either under the category of Disagree and Strongly Disagree or under the category of Agree and Strongly Agree. Since there appeared to be some tendency to Disagree more with these specific items than with the other items, a closer look will be taken at the responses to these specific items in order to use these responses as a basis for formulating some implications for teacher training.

Item 28 dealt with the teachers' perspectives being taken into consideration in the development of the training. Some of the teachers believed that their perspectives had not been taken into consideration in the development of the training. Therefore, it might be beneficial to have a representative group of teachers collaborate in future teacher training development efforts in order to bring their perspectives and their expertise into the teacher training process.

Items 36 and 42 stated similar premises. Item 36 indicated that participation in the META teacher training caused the teachers to modify their approach to teaching, while item 42 indicated that after the META teacher training the teachers felt motivated to change their teaching styles. It appeared according to the responses that for some teachers the teacher training was not sufficient to cause them to modify their teaching style. Therefore, it might be beneficial to more fully prepare teachers to adapt the strategies to their existing classroom situation. The training should provide a clear explanation of the strategies and what they can accomplish and demonstrate fully how the new 
practice can be integrated with the teachers' current mode of presentation within the classroom. However, let us state a caveat for this item. It may be possible that the training did not cause some teachers to modify their teaching styles because these teachers were already aware, being of a minority group themselves, of the necessity of second language instructional strategies and were already implementing these strategies before the training.

Item 40 dealt with follow-up provided by the META teacher training to guide the teacher in incorporating second language instructional strategies into their particular situation. It appeared from the responses that some teachers felt that the META teacher training did not provide follow-up or coaching after the training to guide them in adapting the second language instructional strategies into their particular situation. While it may not be feasible to provide each and every teacher who has been trained with guidance after the training has been completed, it might be possible to set up a hot-line which teachers could contact for information and guidance regarding their particular situation and perhaps request a coaching session. Another option might be to designate a contact person within each school or at least within each teaching level within the feeder pattern who would be available to clarify questions and provide demonstrations. Another option may be to hold a subsequent session, after the teachers have gone back to their classrooms to implement the strategies. At this subsequent follow-up session, the teachers would return to discuss any problems in implementation. If there were no problems, they would be able to share their successful experiences with their colleagues. 
This last option ties into effective staff development practices discussed in the review of literature and from which other implications for training can be drawn. For example, those involved with the planning of staff development should not structure every minute of the training with a specific task. They should provide for a time when teachers can explore their own practices, learn from their experiences, and determine their own direction of change (Harris, 1997; Lieberman, 1994; Microsoft, 1998; Richardson, 1998). In addition, staff development should not just introduce the new strategies or program to be implemented and provide training. It should provide an opportunity for teachers to share their experiences, concerns, and techniques thus building a sense of collegiality and personal relevance (Fullan, 1992; Goldenburg \& Gallimore, 1991; Harris, 1997; Lieberman, 1994; Microsoft, 1998; Minaya-Rowe, 1991; Richardson \& Hamilton, 1994).

\section{CONCLUSION}

Based on the responses of the subjects, the results of this study indicate the overall success of the training implemented to comply with the stipulations set forth in the Consent Decree. In general, the results indicate that the teachers perceive that they are ultimately in agreement with the mandated training. The results also indicate that the teachers perceive a need for second language strategies and the implementation of these strategies when working with language minority students. These results can serve as a starting point for further research not only into teachers' perceptions of the effectiveness of training for teachers of language minority students but also into the outcomes of this teacher training as it is reflected within the classroom. 


\section{RECOMMENDATIONS FOR FUTURE RESEARCH}

This study was designed to gather initial follow-up data regarding the content-area teachers' perceptions of the effectiveness of the teacher training on their instructional practices. The intent was to gather "attitudinal and opinion data concerning the graduates' (teachers') perceptions of the adequacy of their training" (Gay, 1981, p. 158). To this end, it was decided to survey the teachers using a self-administered anonymous questionnaire. Generally speaking, the results of the survey indicated that the content-area teachers perceive the mandated teacher training in a relatively positive manner and consider that they are implementing second language strategies within their classrooms. These findings would appear to indicate that effective instructional practices are being utilized in the classroom with language minority students. Nevertheless, in the review of literature, it was indicated that "it appears likely that a significant gap may exist between prevalent conceptions of effective instructional strategies for language minority students and actual practice" (Mercado \& Sapiens, 1992, p. 6). Consequently, further studies may be necessary to fully assess the actual outcomes of the teacher training mandated by the Consent Decree within the classroom. This study has served to initiate the process of gathering follow-up data concerning the effectiveness of the teacher training. The study was successful in gathering data on the teachers' perceptions. The findings indicated the teachers perceive that the training was effective and that they are implementing second language strategies within the classroom. These findings are positive in that teachers' perceptions concerning what is occurring in their classrooms can be an initial indication of their becoming involved in a process of 
change. The next step in gathering follow-up data on the effectiveness of the training would be to observe actual practices within the classroom. Following are some recommendations for further studies in this area.

1. A study where randomly selected elementary, middle, and secondary school teachers are observed in their classrooms to observe specifically how it is that they implement second language strategies within their content-area.

2. A study contrasting content-area teachers who have been trained and those who have not been trained to observe how their teaching styles differ when they are presenting content-area material to language minority students.

3. A study conducting in-depth interviews and observations of selected elementary, middle, and secondary teachers with whom trust and confidentiality has been established in order to personally elicit qualitative data concerning their perceptions of the training and observe how the strategies acquired through that training transfer into practice.

In addition, the findings also indicate possible future research in another area. According to the results, there was a significant difference in the perceptions of the mandated training between the Hispanic and Black/Non-Hispanic groups and the White/Non-Hispanic group. The Hispanic and Black/Non-Hispanic groups appeared more positive regarding the training than the White/Non-Hispanic group. It might be interesting to conduct further research concerning this difference to see if the same type of results are obtained regarding the implementation of second language strategies within the classroom. Therefore, the following is a recommendation for a study in this area. 
4. A study contrasting the application of second language strategies as observed in the classroom based on the race/ethnicity of the educator.

\section{SUMMARY}

This chapter provided a summary of the study, a discussion of the findings, a summary of the findings including implications for teacher training, and finally, recommendations for future research. 


\section{REFERENCES}

Alreck, P. L., \& Settle, R. B. (1995). The survey research handbook: Guidelines and strategies for conducting a survey. Burr Ridge, Illinois: Irwin Professional Publishing.

Ambert, A. N. \& Melendez, S. E. (1985). Bilingual education: A sourcebook. New York: Garland Publishing Co.

Anders, P. L. \& Richardson, V. (1994) Launching a new form of staff development. In V. Richardson (Ed.), Teacher change and the staff development process: A case in reading instruction. (pp. 1-22). New York: Teachers College Press.

Anderson, T. \& Boyer, M. (1978). Bilingual schooling in the United States (2nd ed). National Education Laboratory Publishers, Inc.

Apple, M. W. (1977). The process and ideology of valuing in educational settings. In A. Bellack \& H. Kliebard (Eds), Curriculum and evaluation (pp. 468-493). California: McCutchan Publishing Corp.

Appleton, N. (1983). Cultural pluralism in education: Theoretical foundations. New York: Longman, Inc.

Applewhite, S. R. (1979). The legal dialect of bilingual education. In R. V. Padilla (Ed), Bilingual education and public policy in the United States (pp. 3-17). Michigan: Department of Foreign Languages and Bilingual Studies Eastern Michigan University.

ASPIRA of New York, Inc. v. Board of Education of New York, 58 F. R. D. $62(1974)$.

Bellack, A. A. (1977). The structure of knowledge and the structure of the curriculum. In A. Bellack \& H. Kliebard (Eds), Curriculum and evaluation (pp. 222-236). California: McCutchan Publishing Corp.

Bennet, K. P. \& LeCompte, M. D. (1990). The way schools work: A sociological analysis of education. New York: Longman. 
Blanco, G. M. (1970). Competencies needed by bilingual education teachers. Educational leadership, 35, 123-127.

Boswell, T. D. (1998). Implications of demographic changes in Florida's public school population [Monograph]. Creating Florida's multilingual global workforce: Policies and practices in assessing and instructing students learning English as a new language (pp. I-1-I-23). Tallahassee, FL. : Florida Department of Education.

Brisk, M. E. (1982). Language policies in American education: A historical overview. In Montero, M. (Ed), Bilingual education teacher handbook (pp. 3-11). Massachusetts: Evaluation, Dissemination and Assessment Center for Bilingual Education.

Broward County Public Schools-Multicultural Education Department (1992). Key features of the consent decree. Ft. Lauderdale, Fl.

Brown, B. (1992). The history of bilingual education in America. California State University, School of Education. (ERIC Document Reproduction Service No. ED 350 874).

Brown v. Board of Education of Topeka, 347 US 483 (1954).

Buchmann, M. (1986). Role over person: Morality and authenticity in teaching. Teachers college record, 87 (4), 529-543.

Castaneda v. Pickard, 648 F. 2d 989 (5th Cir. 1981)

Center for Law and Education. (1992). Rights of limited English proficient students. Cambridge, Ma.

Chin, R. \& Benne, K. D. (1985). General strategies for effecting changes in human systems. In W. G.. Bennis, K. D. Benne \& R. Chin (Eds), The planning of change (4th ed., pp. 22-45). New York: Holt, Reinhart and Winston.

Christensen, J. C.. \& Burke, B. J. (1982, February). Principals and teachers assess professional development in elementary schools. Phi Delta Kappan, 417. 
Christian, D., Spanos, G., Crandall, J., Simich-Dudgeon, C., \& Willetts, K. (1990) Combining language and content for second-language students. In A.M. Padilla, H. H. Fairchild, \& C. M. Valadez (Eds), Bilingual education: Issues and strategies (pp. 141-156). California: Sage Publications, Inc.

Clark, E. (1990). The state of the art in research on teacher training models with special reference to bilingual education teachers. In Proceedings of the first research symposium on limited English proficient students' issues (pp. 361-391). Washington, DC: US Department of Education, Office of Bilingual Education and Minority Language Affairs.

Cuban, L. (1990). Reforming again, again, and again. Educational researcher, $19,(1), 3-13$.

Dade County Public Schools-Division of Bilingual/Foreign Language Skills. (1995). Procedures manual - District LEP plan.

Dade County Public Schools-Division of Bilingual/Foreign Language Skills. (1996). University-school collaboration: A partnership for educational reform in an urban setting. Miami, Fl.

Dalton, S., \& Moir, E. (1991). Evaluating limited English proficient (LEP) teacher training and in-service programs. In Focus on evaluation and measurement: Volumes 1 and 2 Proceedings of the National Research Symposium on Limited English Proficient Student Issues (pp. 415-445). Washington, DC

Delaware State Education Association. (1996a). The mission and principles of professional development. [On-line]. Available: http://www.dmv.com/ dsea/profdevl/profdevl.html

Delaware State Education Association. (1996b). National standards board. [On-line]. Available: http://www.dmv.com/ dsea/profdevl/profdevl/natstdbd.html

Equal Educational Opportunities Act, 20 U.S.C.A.. sec. 1703(f) (1974).

Florida Department of Education-Division of Public Schools-Office of Multicultural Student Language Education. (1995). ESOL resource manual. Tallahassee, Fl. 
Fowler, F. J. Jr. (1993). Survey research methods. (2nd ed). Newbury Park, California: Sage Publications, Inc.

Fradd, S. H. , Wilen, D. K., \& Fardig, D. (1998). Issues in the education of Florida's English language learners [Monograph]. Creating Florida's multilingual global workforce: Policies and practices in assessing and instructing students learning English as a new language (pp. II-1-II-13). Tallahassee, FL. : Florida Department of Education.

Fullan, M. (1992). Successful school improvement. Buckingham, England: Open University Press.

Fullan, M. (1993). Change forces probing the depths of educational reform. London, England: Falmer Press.

Garcia, F. C. \& de la Garza, R. O. (1977). The chicano political experience: Three perspectives. California: Duxbury Press.

Gay, L. R. (1981). Educational research: Competencies for analysis and application. Columbus, Ohio: Charles E. Merrill Publishing Co.

Goldenberg, C. \& Gallimore, R. (1991). Changing teaching takes more than a one-shot workshop. Educational leadership, 49 (3), 69-72.

Gollnick, D. M. \& Chinn, P. C. (1986). Multicultural education in a pluralistic society (2nd ed). Ohio: Bell \& Howell.

Gomez-Quinones, J. (1990). Chicano politics: reality and promise 1940-1990. New Mexico: University of New Mexico Press.

Goodlad, J. I. (1991). Why we need a complete redesign of teacher education. Educational leadership, 49 (3), 4-10.

Goonen, N., Angulo, S., \& Velez, M. (1983). Bilingual education: Florida administrator's manual Section IV. Miami, Fl.: Florida International University School of Education. 
Grant, C. A. (1991). Educational research and teacher training for successfully teaching limited English proficient students. In Focus on evaluation and measurement: Volumes 1 and 2 Proceedings of the National Research Symposium on Limited English Proficient Student Issues (pp. 431-455). Washington, DC.

Grundy, T. (1992). ESL/bilingual education: Policies, programs and pedagogy. Eugene, Or: Oregon School Study Council. (ERIC Document Reproduction Service No. ED 355786.

Hamayan, E. V. (1990). Preparing mainstream classroom teachers to teach potentially English proficient students. In Proceedings of the first research symposium on limited English proficient students' issues (pp. 1-22). Washington, DC: US Department of Education, Office of Bilingual Education and Minority Language Affairs.

Hardaway, R. (1995). America goes to school: Law, reform and crisis in public education. Connecticut: Praeger Publishers.

Harris, A. (1997). The deprofessionalization and deskilling of teachers. In K. Watson, C. Modgil, \& S. Modgil (Eds.), Educational dilemmas: Debate and diversity (Volume one) Teachers, teacher education and training (pp. 57-65). London: Cassel.

Holly, M. L. (1982, February). Teachers' views on inservice training. Phi Delta Kappan, 417-418.

Joyce, B. \& Showers, B. (1980). Improving inservice training: The messages of research. Educational leadership, 37, 379-385.

Joyce, B. \& Showers, B. (1982). The coaching of teaching. Educational leadership, 40, 4-10).

Joyce, B., Showers, B., \& Rolheiser-Bennet, C. (1987). Staff development and student learning: A synthesis of research on models of teaching. Educational Leadership, 43, (3), 11-23.

Kerman, S. (1979). Teacher expectations and student achievement. Phi Delta Kappan, 60, 716-718. 
Klein, M. F. (1991a). A conceptual framework for curriculum decision making. In M. F. Klein (Ed), The politics of curriculum decision making: Issues in centralizing the curriculum (pp. 24-41). Albany, NY: State University of New York Press.

Klein, M. F. (1991b). Issues from curriculum theory in the centralization of curriculum. In M. F. Klein (Ed), The politics of curriculum decision making: Issues in centralizing the curriculum (pp. 210-225). Albany, NY: State University of New York Press.

Kyriacou, C. J. (1996). Schoolteachers' needs: Past, present and future. In C. J. Smith \& V. P. Varma (Eds.), A handbook for teacher development (pp. 1-12). England: Arena Ashgate Publishing Company.

Lam, T. C. (1992). Review of practices and problems in the evaluation of bilingual education. Review of educational research, 62, (2), 181-203.

Lau v. Nichols, 414 US 563, 39L. Ed 2d. 194 S. Ct. 786 (1974).

Lieberman, A. \& Miller, l. (1981). Synthesis of research on improving schools. Educational leadership, 38, 583-586.

Lieberman, A. (1994). Teacher development: Commitment and challenge. In P. P. Grimmet \& J. Neufeld (Eds.), Teacher development and the struggle for authenticity: Professional growth and restructuring in the context of change (pp. 15-30). New York: Teachers College Press. F1. 1990).

LULAC et al v. State Board of Education of Florida Consent Decree. (S.D.

Macias, R. F.. (1979). Choice of language as a human right: Public policy implications in the United States. In R. V. Padilla (Ed), Bilingual education and public policy in the United States (pp. 39-57). Michigan: Department of Foreign Languages and Bilingual Studies, Eastern Michigan University.

Malakoff, M. \& Hakuta, K. (1990). History of language minority education in the United States. In A. M. Padilla, H. H. Fairchild, \& C. M. Valadez (Eds), Bilingual education: Issues and strategies (pp. 27-43). California: Sage Publications, Inc. 
Martinez, R. (1979). Developing an advocacy model in bilingual education: A strategy for program implementation. In R. V. Padilla (Ed), Bilingual education and public policy in the United States (pp. 189-202). Michigan: Department of Foreign Languages and Bilingual Education Studies, Eastern Michigan University.

Matute-Bianchi, M. E. (1979). The federal mandate for bilingual education. In R. V. (Ed) Bilingual education and public policy in the United States (pp. 18-37). Michigan: Department of Foreign Languages and Bilingual Studies, Eastern Michigan University.

McCarthy, C. (1990). Multicultural education, minority identities, textbooks, and the challenge of curriculum reform. Journal of education, 172 , (2), 118-129.

McKay, S. L. \& Weinstein-Shr, G. (1993). English literacy in the U. S.: National policies, personal consequences. TESOL quarterly, 27, (3), 399-419.

Mercado, C. \& Sapiens, A. (1992). Re-thinking the education of teachers of language minority children: Developing reflective teachers for changing schools. Occasional paper in bilingual education. Focus, 6 .

Microsoft. (1998). Professional development: Taking flight. [On-line]. Available: http://www.microsoft.com/education/K12/articles/ccoct $98 . h t m$

Minaya-Rowe, L. (1991). Teacher training in bilingual education and English as a second language: Recent research developments. In A. N. Ambert (Ed), Bilingual education and English as a second language: A research handbook, 1988-1990 (pp. 259-297). New York: Garland Publishing, Inc.

Mohlman, G., Coladarci, T. \& Gage, N. L.. (1982). Comprehension and attitudes as predictors of implementation of teacher training. Journal of teacher education, 33 (1), 31-36.

Office of Civil Rights Memorandum, 35 Fed. Reg. 11595 (May 25, 1970).

Ovando, C. J. \& Collier, V. P. (1985). Bilingual and ESL classrooms: Teaching in multicultural contexts. New York: McGraw-Hill Book Company. 
Padilla, R. V. (Ed) (1979). Bilingual education and public policy in the United States (pp. vii-xi). Michigan: Department of Foreign Languages and Bilingual studies, Eastern Michigan University.

Phillips, C. B. (1988). Nurturing diversity for today's children and tomorrow's leaders. Young children, $43,42-47$.

The Policy Dilemma. (1994). In Systemic reform: Perspectives on personalizing education [On-line]. Available: http//www.ed.gov/pubs/EdReformstudies/sysreforms/little2.html

Prawat, R. S. (1992). Teachers' beliefs about teaching and learning: A constructivist perspective. American journal of education, 100 (3), 354-395.

Ramos v. La Fontaine, D. Conn., C. A No. H-76-38 (1976).

Reagan, T. (1985). Cultural unity, cultural pluralism, and the school: Toward a pedagogical synthesis. Journal of research and development in education, 18 (2), 21-25.

Richardson, V. (1994). The consideration of teachers' beliefs. In V. Richardson (Ed.), Teacher change and the staff development process: A case in reading instruction. (pp. 90-103). New York: Teachers College Press.

Richardson, V. (November 15, 1998). How teachers change: What will lead to change that most benefits student learning? [On-line]. Available: http://hugse1. harvard.edu/ NCSALL/richards.htm

Richardson, V. \& Hamilton, M. L. (1994). The practical-argument staff development process. In V. Richardson (Ed.), Teacher change and the staff development: A case in reading instruction (pp. 109-134). New York: Teachers College Press.

Rios v. Reed, 75 C. 296 , E.D. NY (1977).

Rossi, P. H., Wright, J. D., \& Anderson, A. B. (Eds). (1983). Handbook of survey research. Orlando, Florida: Academic Press, Inc.

Scarcella, R. (1990). Teaching language minority students in the multicultural classroom. Englewoods Cliffs, New Jersey: Prentice-Hall, Inc. 
Schubert, W. H. (1986). Curriculum: Perspective, paradigm and possibility. New York: Macmillan Publishing Company.

Schwartz, A. J. (1991). Organizational metaphors, curriculum reform, and local school and district change. In M. F.. Klein (Ed), The politics of curriculum decision making: Issues in centralizing the curriculum (pp. 167-197). Albany, New York: State University of New York Press.

Scribner-Bantam English dictionary. (1991). New York: Bantam Books.

Serna v. Portales, 499F. 2d, 1147-1154 (10th Cir.. 1974).

Short, D. J. (1998). Social studies instruction and assessment: Meeting the needs of students learning English [Monograph]. Creating Florida's multilingual global workforce: Policies and practices in assessing and instructing students learning English as a new language (pp. VI-1-VI-12). Tallahassee, FL. : Florida Department of Education.

Sonquist, J. A., \& Dunkelberg, W. C.. (1977). Survey and opinion research: Procedures for processing and analysis. Englewood Cliffs, New Jersey: Prentice-Hall, Inc.

Sparks, G. M. (1983). Synthesis of research on staff development for effective teaching. Educational leadership, 41 (3), 65-72.

Spener, D. (1988). Transitional bilingual education and the socialization of immigrants. Harvard Educational Review, 58 (2), 133-153.

Suzuki, B. H.. (1984). Curriculum transformation for multicultural education. Education and urban society, 16 (3), 294-322.

Stevens, J. (1996). Applied multivariate statistics for the social sciences, (3rd ed). New Jersey: Lawrence Erlbaum Associates Publishers.

Tatto, M. T. (1998). The influence of teacher education on teachers' beliefs about purposes of education, roles and practice. Journal of teacher education, 49 (1), 66-77. 
Valle, M., Franco, R. \& Rodriguez-Garcia, C. (1979). Law and bilingual education: An examination of the litigation strategy. In R. V. Padilla (ed), Bilingual education and public policy in the United States (pp. 58-82). Michigan: Department of Foreign Languages and Bilingual Studies, Eastern Michigan University.

Weismantal, J. M. \& Fradd, S. H. (1989). Understanding the need for change. In S. H. Fradd \& J. M. Weismantal (Eds.), Meeting the needs of culturally and linguistically different students: A handbook for educators (pp. 1-13). Massachusetts: College-Hill Press.

Wiley, T. G. (1993). Discussion of Klassen \& Burnaby and McKay \& Weinstein-Shr: Beyond assimilationist literacy policies and practices. TESOL quarterly, 27 (3), 421-430.

Wright, D. A. \& Fair, S. C. (1992). Barriers to information access: Strategies for teaching library skills and information literacy. In C. Grant (Ed.), Multicultural education for the twenty-first century: Proceedings of the second annual National Association for Multicultural Education February 13-16, 1992. (pp. 243-250) New Jersey: Paramount Publishing Silver Burdell Ginn, Inc.

Wood, F. H., McQuarrie Jr., F. O., \& Thompson, S. R. (1982). Practitioners and professors agree on effective staff development practices, Educational leadership, 40, 28-31.

Zehler, A.M. (1994). Working with English language learners: Strategies for elementary and middle school teachers. (Program Information Guide Series No. 19). Washington, DC: National Clearinghouse for Bilingual Education. (ERIC Document Reproduction Service No. 381 022). 
APPENDICES 


\section{APIPNIIX A}

\section{DADE COUNTY PUBLIC SCHOOLS}

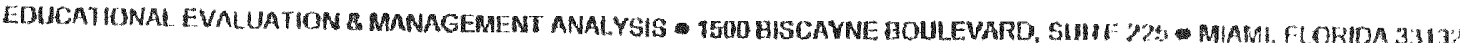

Roger C. Cuovas

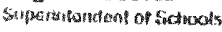

Robnt A. Colmo

Focabive thectes

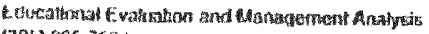

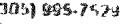

A A 00067

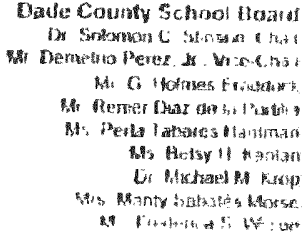

Decemher 2, 1997

Sylvia A. Craspo

5,510 S.W. 194 Avenue

1. Laudenale, Farila 33332

Dear Ms. Cresno:

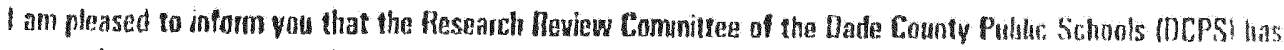

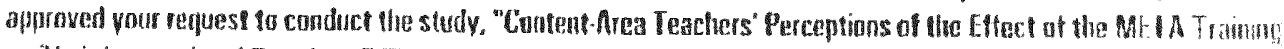
on Their Instrotional Pratices." The approval is granted with the following canditions:

1. The particination of all subjects is volunlary.

2. The anonymity ant confidentiality of all subjects must brossuret.

3. The study will involve apnroxmatefy 400 OCPS regchars.

1. The DCPS intemal sctnol mail system cannot be used in conducting the sfuly.

It should the emphasized that the approwal of the Research Review Conmiltee does not constitute an endorgenent of

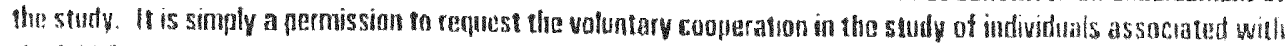

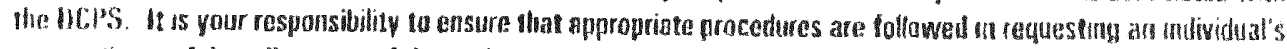

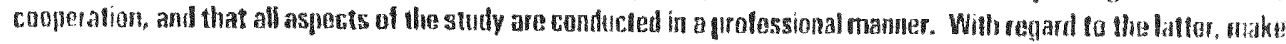
cenain that all documents and ins?uments distibuted within the Drps as a part of the sludy are carchally cthed.

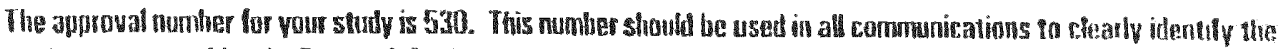

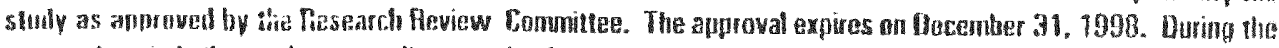
nuproval penod, the stuty mus athero to the design, procoduras and instruments which were suluntted tu the

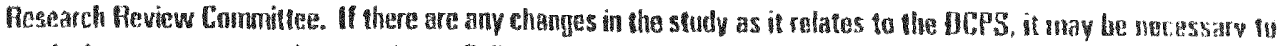

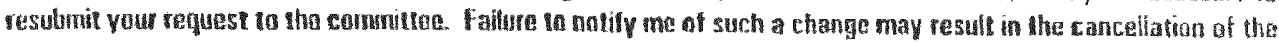
approval. 
If you havo : ay questions, please call ne at (305) 995.7501 . Finally, cemember to fnoward an ahs lract of the study when it is complote. In behalf al the Rosearch Heview Cnmmittes, I want to wish you gvery success with your study.

Sincerely,

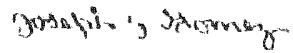

Joseph J. G imez, Ph.I.

Chairpersan

Besearch to visw Committes

JJG:CI

APPAOVAL NUMGER: 530

APPROUAL EXPIRES: 1239.9A 


\section{APPENDIX B}

August 4, 1997

Biscayne Gardens Elementary

Miami, Florida 33169

Dear

As the final step in completing the requirements for the doctoral degree in Instructional Leadership from Florida International University, I am piloting an effectiveness survey. The final survey should provide information regarding the effectiveness of the teacher training mandated by the Consent Decree.

As an educator who has participated in the mandatory training and who is now involved with the language minority students present in your class, your responses to the pilot survey will be a valuable source of information. Your feedback concerning the directions, recording procedures, specific items, response time, and length of survey will be invaluable in editing the survey will be invaluable in editing the survey to arrive at the final version. A form on which to record your comments has been provided for ease of response.

Please return the completed pilot survey with all of your comments in the envelope provided by August 8, 1997.

Thank you for taking the time to complete the survey and for providing feedback.

Your assistance in this project is greatly appreciated.

Sincerely,

\section{Sylvia Crespo}

PS. Please feel free to write any comments that you wish to directly on the survey form. Also if you would write your name on the response form it would help a lot, that way I can get in touch with you if I have any questions. Again, thanks for your input, I really appreciate it. 


\section{APPENDIX C}

\section{Pilot Survey Response Form}

Please record your comments regarding the survey below.

Time needed to complete survey:

Comments:

Length of survey

Comments:

Clarity of directions

Comments:

Procedure for recording responses

Comments:

Comments on specific survey items:

Comments in general: 


\section{APPENDIX D}

\section{Pilot Survey Questions}

This survey is designed to gather information relating to the impact the teacher training mandated by the Consent Decree has had on instruction within the content-area classes.

The first items are designed to provide the researcher with demographic information. The statements that follow describe ways in which the implementation of the Consent Decree and the mandated teacher training might be perceived. The only purpose of the survey is to make it possible to record your perceptions of the effectiveness of implementing the methods presented in the teacher training within the content-area classes. All information in the survey is confidential and will be used for research purposes only. Your answers will remain anonymous.

\section{DIRECTIONS (items 1-11)}

Complete each statement below by marking the correct response or by filling in the information requested.

1. What is your gender?

1. Male

2. Female

2. What is your race?

1. White

2. Black

3. Yellow

4. Multiracial

3. In what year were you born?

4. Were you born in the United States?

1. Yes

2. No

5. Do you speak another language besides English?

1. Yes

2. No 
6. If yes, what language(s) other than English do you speak?

1. Spanish

2. French

3. Haitian-Creole

4. Other

7. In what year did you start teaching?

8. What is your teaching assignment?

1. Early Childhood

2. Elementary School

3. Middle School

4. High School

9. Which content-area do you teach?

1. All Subjects (Early Childhood/Elementary)

2. English

3. Mathematics

4. Science

5. Social Studies

6. Computer Literacy

10. How did you comply with the META teacher training requirements mandated by the Consent Decree?

1. Through a course offered by a university

2. Through the telecourse offered by the Dade County Public Schools

11. In what year did you complete the teacher training requirements mandated by the Consent Decree?

\section{DIRECTIONS (items 12-44)}

Read each item carefully. Use the scale below each item to indicate your degree of agreement or Disagreement with the concept presented. Circle the number to indicate your response.

12. The Consent decree provides Limited English Proficient (LEP) students with more rights than other students have.
1. Strongly Disagree
2. Disagree
3. Neutral
4. Agree
5. Strongly Agree 
13. Second language instructional strategies geared to the LEP students facilitate their ability to comprehend the content-area lesson better.

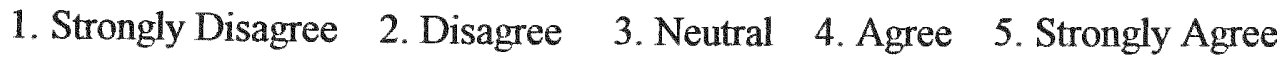

14. Second language instructional strategies geared towards the LEP students facilitate their social development.
1. Strongly Disagree
2. Disagree
3. Neutral
4. Agree
5. Strongly Agree

15. Second language instructional strategies geared towards the LEP students allow them to experience greater academic success in the content areas.

\section{Strongly Disagree $\quad$ 2. Disagree 3 . Neutral 4 . Agree 5 . Strongly Agree}

16. Second language instructional strategies learned through the META teacher training are helpful to me in meeting the LEP students' language needs.

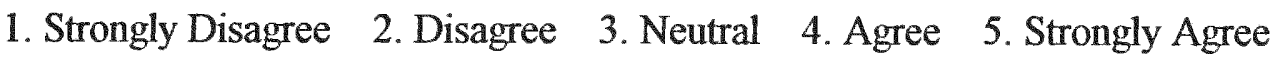

17. LEP students do not require special second language instructional strategies within the content-area classes.

\section{Strongly Disagree $\quad$ 2. Disagree 3 . Neutral $\quad 4$. Agree $\quad$ 5. Strongly Agree}

18. LEP students require second language instructional strategies geared to their individual level of English proficiency.

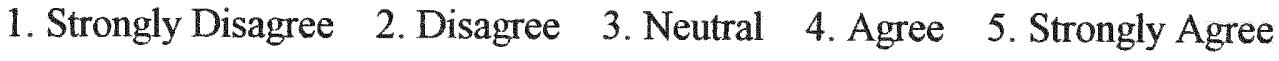

19. Second language instructional strategies geared towards LEP students are necessary in order to provide them with equal educational opportunity.
1. Strongly Disagree
2. Disagree
3. Neutral
4. Agree
5. Strongly Agree

20. The Consent Decree is the first piece of legislation to impact directly on the educational opportunities offered to LEP students.
1. Strongly Disagree
2. Disagree
3. Neutral
4. Agree
5. Strongly Agree 
21. The META teacher training made me aware of the instructional needs of the LEP student.
1. Strongly Disagree
2. Disagree
3. Neutral
4. Agree
5. Strongly Agree

22. Teaching the LEP student should be the responsibility only of the teachers in the Bilingual Program.
1. Strongly Disagree
2. Disagree
3. Neutral
4. Agree
5. Strongly Agree

23. After participation in the teacher training, I felt that the training required by the Consent Decree was valuable.
1. Strongly Disagree
2. Disagree
3. Neutral
4. Agree
5. Strongly Agree

24. The deadline for the completion of META teacher training was reasonable.
1. Strongly Disagree
2. Disagree
3. Neutral
4. Agree
5. Strongly Agree

25. The number of hours of teacher training required to comply with the Consent Decree were reasonable.
1. Strongly Disagree
2. Disagree
3. Neutral
4. Agree
5. Strongly Agree

26. Participation in META teacher training should be voluntary rather than mandatory.
1. Strongly Disagree
2. Disagree
3. Neutral
4. Agree
5. Strongly Agree

27. The teacher training required through the Consent Decree provided an opportunity for professional growth.
1. Strongly Disagree
2. Disagree
3. Neutral
4. Agree
5. Strongly Agree

28. The teacher training mandated by the a Consent Decree was beneficial.
1. Strongly Disagree
2. Disagree
3. Neutral
4. Agree
5. Strongly Agree 
29. The teacher training mandated by the Consent Decree took the teachers' perspectives into consideration in its development.

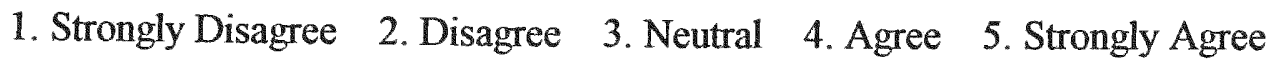

30. After participating in the META teacher training I felt I had knowledge of the legal basis for the training.
1. Strongly Disagree
2. Disagree
3. Neutral
4. Agree
5. Strongly Agree

31. The Consent Decree was a necessary piece of legislation.
1. Strongly Disagree
2. Disagree
3. Neutral
4. Agree
5. Strongly Agree

32. Prior to participation in META teacher training I thought the training had limited value.
1. Strongly Disagree
2. Disagree
3. Neutral
4. Agree
5. Strongly Agree

33. After participation in META teacher training, I realized the importance of the training.
1. Strongly Disagree
2. Disagree
3. Neutral
4. Agree
5. Strongly Agree

34. After the META teacher training, I feel competent using second language instructional strategies in the content-area classroom.
1. Strongly Disagree
2. Disagree
3. Neutral
4. Agree
5. Strongly Agree

35. Second language instructional strategies are easy to implement within the content-area classroom setting.
1. Strongly Disagree
2. Disagree
3. Neutral
4. Agree
5. Strongly Agree

36. The second language instructional strategies presented through the META teacher training were useful.
1. Strongly Disagree
2. Disagree
3. Neutral
4. Agree
5. Strongly Agree 
37. Participation in the META teacher training caused me to modify my approach to teaching.
1. Strongly Disagree
2. Disagree
3. Neutral
4. Agree
5. Strongly Agree

38. The teacher training mandated by the Consent Decree increased my professional expertise.
1. Strongly Disagree
2. Disagree
3. Neutral
4. Agree
5. Strongly Agree

39. The second language instructional strategies presented in the META teacher training were compatible with my educational philosophy.
1. Strongly Disagree
2. Disagree
3. Neutral
4. Agree
5. Strongly Agree

40. The META teacher training provided me with practice and feedback on my development of second language instructional strategies.
1. Strongly Disagree
2. Disagree
3. Neutral
4. Agree
5. Strongly Agree

41. The META teacher training provided follow-up to guide me in incorporating second language instructional strategies into my particular situation.
1. Strongly Disagree
2. Disagree
3. Neutral
4. Agree
5. Strongly Agree

42. Second language instructional strategies are incorporated into my daily teaching routine.
1. Strongly Disagree
2. Disagree
3. Neutral
4. Agree
5. Strongly Agree

43. After the META teacher training I felt motivated to change my teaching style.
1. Strongly Disagree
2. Disagree
3. Neutral
4. Agree
5. Strongly Agree

44. The META teacher training prepared me to adapt second language instructional strategies in my classroom.
1. Strongly Disagree
2. Disagree
3. Neutral
4. Agree
5. Strongly Agree 


\section{APPENDIX E}

\section{Survey Cover Letter}

Dear

As the final step in completing the requirements for the doctoral degree in Instructional Leadership from Florida International University, I am conducting an effectiveness survey. The survey should provide information regarding the effectiveness of the teacher training mandated by the Consent Decree.

As an educator who has participated in the mandatory training and who is now involved with the language minority students present in your class, your responses to the survey will be a valuable source of information. Your feedback will provide information as to the extent educators feel the training was beneficial.

All information gathered from this survey will be used solely for research purposes and all responses will be strictly anonymous. Your packet includes a postcard which when returned allows me to verify who has responded but does not allow me to match the postcard to the survey. The survey itself contains no identifiable data and is completely anonymous.

I realize that your time is extremely valuable; therefore, the survey has been developed in a format that will provide a maximum amount of information while requiring a minimum amount of time to complete.

Your knowledge, experience, and opinions are truly a valuable source of information for this research study. I am asking you to please comp[let the survey and return it as soon as possible in the envelope provided. Drop the postcard in the mail separately.

Thank you for taking the time to complete the survey. Your assistance in this project is greatly appreciated.

Sincerely,

Sylvia Crespo

Doctoral Student

Florida International University 


\section{APPENDIX F}

\section{Survey Questions}

This survey is designed to gather information relating to the impact the teacher training mandated by the Consent Decree has had on instruction within the content-area classes.

The first items are designed to provide the researcher with demographic information. The statements that follow describe ways in which the implementation of the Consent Decree and the mandated teacher training might be perceived. The only purpose of the survey is to make it possible to record your perceptions of the effectiveness of implementing the methods presented in the teacher training within the content-area classes. All information in the survey is confidential and will be used for research purposes only. Your answers will remain anonymous.

\section{DIRECTIONS (items 1-11)}

\section{Complete each statement below by marking the correct response or by filling in} the information requested.

1. What is your gender?

1. Male

2. Female

2. What is your racial/ethnic group?

1. American Indian/Native Alaskan

2. Asian Pacific Islander

3. Black/Not Hispanic

4. White/Not Hispanic

5. Hispanic

3. In what year were you born?

4. Were you born in the United States?

1. Yes

2. No

5. Do you speak another language besides English?

1. Yes

2. No 
6. If yes, what language other than English do you speak?

1. Spanish

2. French

3. Haitian-Creole

4. Other

7. In what year did you start teaching?

8. What is your teaching assignment?

1. Early Childhood

2. Elementary School

3. Middle School

4. High School

9. Which content-area do you teach?

1. All Subjects (Early Childhood/Elementary)

2. English

3. Mathematics

4. Science

5. Social Studies

6. Computer Literacy

10. How did you comply with the META teacher training requirements mandated by the Consent Decree?

1. Through a course offered by a university

2. - Through the telecourse offered by the Dade County Public Schools

11. In what year did you complete the teacher training requirements mandated by the Consent Decree?

\section{DIRECTIONS (items 12-44)}

Read each item carefully. Use the scale below each item to indicate your degree of agreement or Disagreement with the concept presented. Circle the number to indicate your response.

12. The Consent decree provides Limited English Proficient (LEP) students with more rights than other students have.

\section{Strongly Disagree 2. Disagree 3. Neutral 4. Agree 5. Strongly Agree}


13. Second language instructional strategies geared to the LEP students facilitate their ability to comprehend the content-area lesson better.

\section{$\begin{array}{llll}\text { 1. Strongly Disagree } & \text { 2. Disagree } & \text { 3. Neutral } & \text { 4. Agree } \quad 5 . \text { Strongly Agree }\end{array}$ \\ 14. Second language instructional strategies geared towards the LEP students facilitate their social development.}

\section{$\begin{array}{llll}\text { 1. Strongly Disagree } & \text { 2. Disagree } & \text { 3. Neutral } & \text { 4. Agree } \quad 5 . \text { Strongly Agree }\end{array}$}

15. Second language instructional strategies geared towards the LEP students allow them to experience greater academic success in the content areas.

\section{Strongly Disagree $\quad$ 2. Disagree 3 . Neutral 4 . Agree $\quad 5$. Strongly Agree}

16. Second language instructional strategies learned through the META teacher training are helpful to me in meeting the LEP students' language needs.

\section{Strongly Disagree 2. Disagree 3. Neutral 4 . Agree $\quad$ 5. Strongly Agree}

17. LEP students require second language instructional strategies geared to their individual level of English proficiency.

\section{Strongly Disagree $\quad 2$. Disagree 3 . Neutral $\quad$ 4. Agree $\quad 5$. Strongly Agree}

18. Second language instructional strategies geared towards LEP students are necessary in order to provide them with equal educational opportunity.

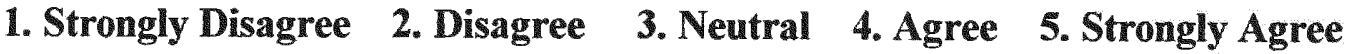

19. The Consent Decree is the first piece of legislation to impact directly on the educational opportunities offered to LEP students.

\section{Strongly Disagree $\quad 2$. Disagree $\quad 3$. Neutral $\quad 4$. Agree $\quad 5$. Strongly Agree}

20. The META teacher training made me aware of the instructional needs of the LEP student.
1. Strongly Disagree
2. Disagree
3. Neutral
4. Agree
5. Strongly Agree 
21. Teaching the LEP student should be the responsibility only of the teachers in the Bilingual Program.

\section{$\begin{array}{llll}\text { 1. Strongly Disagree } & \text { 2. Disagree } & 3 . \text { Neutral } & 4 . \text { Agree } \quad 5 . \text { Strongly Agree }\end{array}$}

22. After participation in the teacher training, I felt that the training required by the Consent Decree was valuable.

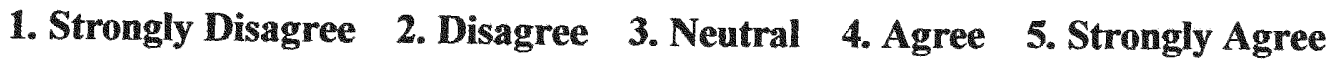

23. The deadline for the completion of META teacher training was reasonable.

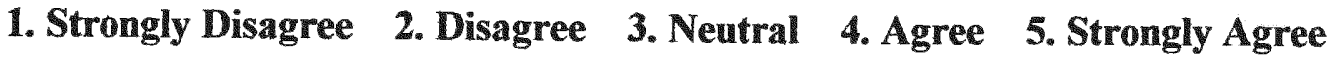

24. The number of hours of teacher training required to comply with the Consent Decree were reasonable.

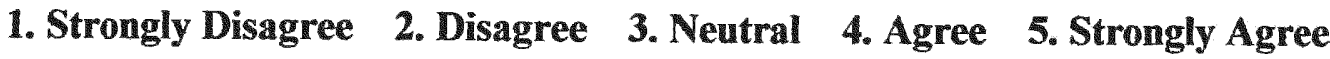

25. Participation in META teacher training should be voluntary rather than mandatory.

\section{Strongly Disagree $\quad$ 2. Disagree $\quad 3$. Neutral $\quad 4$. Agree $\quad$ 5. Strongly Agree}

26. The teacher training required through the Consent Decree provided an opportunity for professional growth.

\section{Strongly Disagree 2. Disagree 3 . Neutral $\quad 4$. Agree $\quad$ 5. Strongly Agree}

27. The teacher training mandated by the a Consent Decree was beneficial.

\section{Strongly Disagree 2. Disagree $\quad 3$. Neutral $\quad 4$. Agree 5. Strongly Agree}

28. The teacher training mandated by the Consent Decree took the teachers' perspectives into consideration in its development.
1. Strongly Disagree
2. Disagree
3. Neutral
4. Agree
5. Strongly Agree 
29. After participating in the META teacher training I felt I had knowledge of the legal basis for the training.

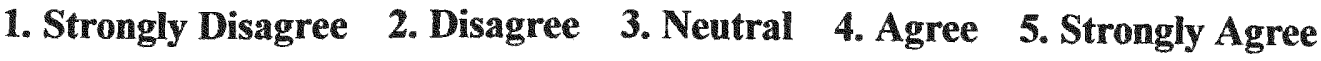

30. The Consent Decree was a necessary piece of legislation.

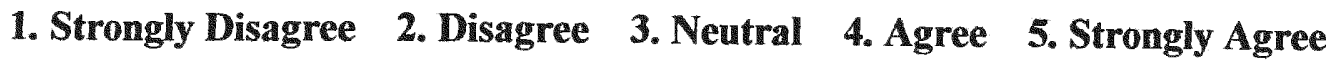

31. Prior to participation in META teacher training I thought the training had limited value.

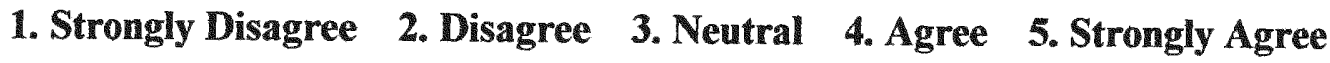

32. After participation in META teacher training, I realized the importance of the training.

\section{Strongly Disagree 2. Disagree 3. Neutral 4. Agree $\quad 5$. Strongly Agree}

33. After the META teacher training, I feel competent using second language instructional strategies in the content-area classroom.

\section{$\begin{array}{llll}\text { 1. Strongly Disagree } & \text { 2. Disagree } & 3 \text {. Neutral } & 4 \text {. Agree } \quad 5 . \text { Strongly Agree }\end{array}$}

34. Second language instructional strategies are easy to implement within the content-area classroom setting.

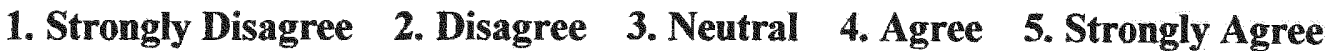

35. The second language instructional strategies presented through the META teacher training were useful.

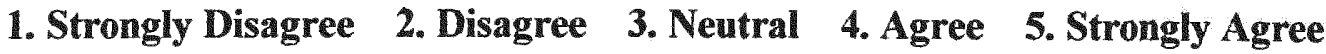

36. Participation in the META teacher training caused me to modify my approach to teaching.
1. Strongly Disagree
2. Disagree
3. Neutral
4. Agree
5. Strongly Agree 
37. The teacher training mandated by the Consent Decree increased my professional expertise.

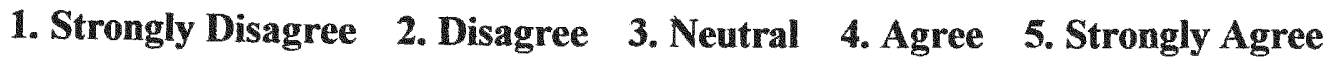

38. The second language instructional strategies presented in the META teacher training were compatible with my educational philosophy.

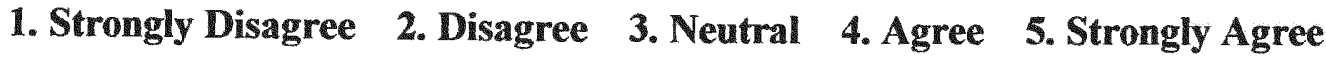

39. The META teacher training provided me with practice and feedback on my development of second language instructional strategies.

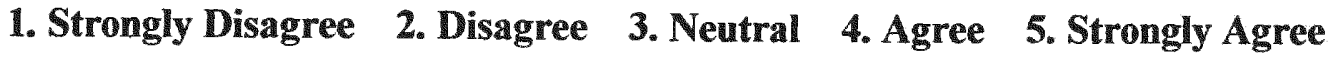

40. The META teacher training provided follow-up to guide me in incorporating second language instructional strategies into my particular situation.

\section{$\begin{array}{llll}\text { 1. Strongly Disagree } & \text { 2. Disagree } & \text { 3. Neutral } & \text { 4. Agree } \quad 5 \text {. Strongly Agree }\end{array}$}

41. Second language instructional strategies are incorporated into my daily teaching routine.

\section{$\begin{array}{llll}\text { 1. Strongly Disagree } & \text { 2. Disagree } & \text { 3. Neutral } & \text { 4. Agree } \quad 5 . \text { Strongly Agree }\end{array}$}

42. After the META teacher training I felt motivated to change my teaching style.

\section{Strongly Disagree $\quad 2$. Disagree 3 . Neutral $\quad 4$. Agree $\quad 5$. Strongly Agree}

43. The META teacher training prepared me to adapt second language instructional strategies in my classroom.

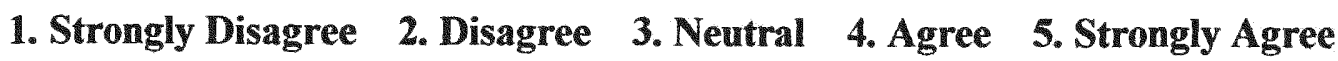




\section{VITA}

\section{SYLVIA CRESPO}

February 7, 1955

1976

1977-1980

1980-1981

1981-1996

1986

1986

1987

1991
Born, Newark, New Jersey

B. A., Elementary Education Magna Cum Laude University of Puerto Rico

Rio Piedras, Puerto Rico

English Teacher

Maria T. Serrano Elementary

Carolina, Puerto Rico

English Teacher

Cesario R. Nieves Junior High

Rio Piedras, Puerto Rico

ESOL Teacher

Biscayne Gardens Elementary

Miami, Florida

M. S., Elementary Education Florida International University

Miami, Florida

Academic Excellence Award College of Education

Florida International University

Miami, Florida

Certification in TESOL Florida International University Miami, Florida

PTA Recognition

Biscayne Gardens Elementary

Miami, Florida 
1991-1993

1993-1994

1995-1996

1996-1998

Presentations

1992

1993
Adjunct Instructor

Florida International University

Miami, Florida

Region II Teacher of the Year

Dade County Public Schools

Miami, Florida

Teacher Trainer

Division of Bilingual/Foreign Language

Skills

Dade County Public Schools

Miami. Florida

Bilingual Assessor

Bilingual/ESOL ESE Program

Division of Exceptional Student

Education

Miami-Dade County Public Schools
Facilitator

Bilingual/ESOL ESE Parent Education

Program Workshops

Division of Exceptional Student Education

Dade County Public Schools

Miami, Florida

Presenter

Competency Based Curriculum

Subject Area Meeting

Division of Bilingual/Foreign Language

Skills

Dade County Public Schools

Miami, Florida 